UNIVERSIDADE DE SÃO PAULO

FACULDADE DE FILOSOFIA, LETRAS E CIÊNCIAS HUMANAS

DEPARTAMENTO DE FILOSOFIA

PROGRAMA DE PÓS-GRADUAÇÃO EM FILOSOFIA

\title{
MODERNIDADE, TRADIÇÃO E CARÁTER NACIONAL NA OBRA DE ALBERTO DA VEIGA GUIGNARD
}

\author{
TAisa Helena Pascale PalHares
}

Tese apresentada ao programa de PósGraduação do Departamento de Filosofia da Faculdade de Filosofia, Letras e Ciências Humanas da Universidade de São Paulo para obtenção do título de Doutora em Filosofia.

Orientador: Prof. Dr. Lorenzo Mammì

São Paulo

2010 
UNIVERSIDADE DE SÃO PAULO

FACULDADE DE FILOSOFIA, LETRAS E CIÊNCIAS HUMANAS

DEPARTAMENTO DE FILOSOFIA

PROGRAMA DE PÓS-GRADUAÇÃO EM FILOSOFIA

MODERNIDADE, TRADIÇÃO E CARÁTER NACIONAL NA OBRA DE ALBERTO DA VEIGA GUIGNARD

Taisa Helena Pascale Palhares

São Paulo

2010 


\section{AgRAdECIMENTOS}

Ao meu orientador Prof. Dr. Lorenzo Mammì pela paciência, generosidade intelectual e confiança, e sem cuja presença compreensiva nos últimos anos esta tese não teria sido realizada.

Aos membros da banca do exame de qualificação, Sônia Salzstein e Rodrigo Naves, pelas valiosas críticas e sugestões.

Ao CNPq pelo apoio financeiro para a execução da pesquisa.

Aos funcionários da secretaria do Departamento de Filosofia da USP, particularmente a Maria Helena Barboza e a Mariê Pedroso Morais.

No Brasil, qualquer trabalho sobre artes visuais só é levado a cabo com a generosidade de diversas instituições e colecionadores que são gentilmente capazes de abrir suas portas aos pesquisadores. Neste caso não seria diferente. Por isso, gostaria de agradecer imensamente às seguintes pessoas e instituições: Piedade Grinberg, que me deixou consultar sem restrições o material do Arquivo Pesquisa Guignard da PUC-Rio; a Gélcio Fortes, diretor do Museu Casa Guignard em Ouro Preto; a Priscila Freire e aos conservadores do Museu de Arte da Pampulha, em Belo Horizonte; aos conservadores e 
bibliotecários do Museu de Arte Moderna do Rio de Janeiro, do Museu Nacional de BelasArtes, do Museu de Arte Moderna de São Paulo e do Museu de Arte Contemporânea da Universidade de São Paulo; Telê Ancona Lopez e ao Instituto de Estudos Brasileiros da USP; à Akademie der Bildende Künste de Munique; ao Stadtarchiv München; ao Zentrale Institut für Kunstgeschichte em Munique; Lílian Tone, Jennifer Schauer e Kathy Curry do Museum of Modern Art de Nova York; ao Instituto Moreira Salles; Sra. Ângela Gutierrez; Sra. Terezinha e Sr. Levínio Castilho; Sra. Adriana Crespi; Sr. Max Perlingeiro da Pinakotheke Cultural.

Em 2007 eu fui convida pelo Museu de Arte Moderna de São Paulo, em nome de seu curador Felipe Chaimovich, a organizar uma pequena mostra sobre a arte brasileira da década de 1940. Tanto a pesquisa quanto a curadoria desta exposição foram fundamentais para os desdobramentos de minha tese. Por isso, gostaria de agradecer ao museu a oportunidade e apoio para realização da mostra "Modernidade Negociada: um recorte da arte brasileira nos anos 40", principalmente à pesquisadora Carolina Coelho Soares e Andrés Martín Hernández.

Em 2009, o curador José Augusto Ribeiro organizou a exposição “Guignard: um mundo a perder de vista”, na Fundação Iberê Camargo, em Porto Alegre. A ele agradeço duplamente: primeiro pela chance de poder ver ou rever obras da mais alta qualidade, geralmente de difícil acesso; em segundo lugar pelo convite em participar do colóquio sobre o artista, no qual foi apresentado o esboço do meu primeiro capítulo.

Entre 2006 e 2007 eu participei das reuniões do Centro de Pesquisas em Arte Brasileira do Departamento de Artes Plásticas da ECA-USP sob coordenação da Profa. 
Sônia Salzstein, formado por alunos de graduação e pós-graduação. Nesses encontros foram discutidas diversas abordagens sobre arte brasileira e teoria da arte em geral que enriqueceram sobremaneira a minha visão. Por isso, gostaria de agradecer ao grupo, na época constituído por Ana Luiza Dias Batista, José Augusto Ribeiro, Liliane Benedetti, Milton Ohata, Marcelo Berg e Thaís Rivitti. E mais uma vez a Sônia, pela oportunidade de realizar sob sua supervisão estágio PAE na disciplina “Evolução das Artes Visuais - III” no primeiro semestre de 2007, neste mesmo Departamento.

Esse trabalho não teria sido possível sem o apoio cotidiano que recebo de meus colegas da Pinacoteca do Estado de São Paulo. Por isso, eu gostaria de registrar minha gratidão a Marcelo Mattos Araújo e a Ivo Mesquita, pela compreensão, confiança e muito mais. E particularmente aos amigos e amigas do Setor de Pesquisa em Crítica e História da Arte com quem trabalhar e conviver é um enorme prazer, especialmente à Regina Teixeira de Barros, pelo bom-humor, sensibilidade e remedinhos na reta final; à Valéria Piccoli pela serenidade e companheirismo; à Juliana Ripoli, minha queridíssima Juju, que me dá força em todos os sentidos e também me auxiliou com as imagens e na organização da bibliografia.

São longos e por vezes conturbados os anos de duração de uma tese de doutorado. Assim queria agradecer a todos os amigos que de uma forma ou de outra me ajudaram, com carinho, suporte, comentários aos textos ou bate-papos informais sobre coisas da arte e da vida: Cauê Alves, Fernanda Pitta, Thaís Rivitti, Tatiana Ferraz, Tânia Rivitti, Priscila Figueiredo, Elizabeth Jobim, Célia Euvaldo, Izilda Johanson, José Augusto Ribeiro, Heloisa Espada, Paulo Monteiro, Carla Zaccagnini, Gerty Saruê, Thiago Honório, Sônia 
Salzstein, Fábio Miguez, Rodrigo Andrade, Alberto Tassinari, Gisele Camargo, Sérgio Sister, Rodrigo Naves, Cassio Michalany, Paulo Pasta, Carolina Soares, Jimena J. Garcia, Olgária C. F. Matos e Tiago Mesquita.

A minha família, principalmente a minha irmã, Ana Luísa, que com sua doçura e paciência infindáveis me ajuda muito mais do que possa imaginar. Às irmãs de coração Renata Paludetto e Sílvia S. Trawny e suas lindas famílias, sempre tão importantes em momentos cruciais. Ao Rodnei, pelo companheirismo.

Este trabalho é inteiramente dedicado ao João Paulo, meu pequeno com quem aprendo todo dia a ser uma pessoa melhor. 


\section{RESUMO}

A presente tese tem como objetivo analisar as relações entre linguagem moderna, tradição, caráter nacional e lirismo na obra do artista plástico Alberto da Veiga Guignard (1896-1962). Ela visa compreender como se constrói, a partir do aprofundamento de suas fontes e influências, o espaço singular de seus trabalhos. Este se caracteriza, sobretudo, por sua espacialidade ambígua, no limiar entre a profundidade ilusionista da arte tradicional e a planaridade da pintura moderna, constituindo-se como uma das características decisivas de sua produção.

Nossa abordagem não propõe um percurso cronológico, ao contrário, procura explicitar como, ao longo de sua carreira, diversos elementos estéticos são reiterados até atingirem um alto poder de síntese em paisagens realizadas do início dos anos 1950 até o final de sua vida. Em primeiro lugar, analisamos como se deu a recepção crítica inicial da obra de Guignard, ainda marcada por uma leitura de viés nacionalista, para destacar suas características decisivas, independentes de sua temática. Em seguida, retornamos a seu período de formação na Europa a fim de elucidar a relação com a produção artística da época. Examinamos também como sua poética dialoga com questões importantes do meio artístico brasileiro das décadas de 1930 e 1940 como, por exemplo, a revalorização da visualidade popular. A nosso ver, suas paisagens respondem de maneira dialética à dinâmica particular do modernismo no Brasil, estabelecendo-se como um momento privilegiado para sua compreensão.

Palavras-chave: Alberto da Veiga Guignard; arte moderna; tradição; cultura popular; espaço; paisagem; Modernismo brasileiro. 


\begin{abstract}
This thesis aims to analyze the relationship between modern language, artistic tradition, national character and lyricism in the work of the artist Alberto da Veiga Guignard (1896-1962). It seeks to understand how the singular space of his works is built from the deepening of its sources and influences. This is characterized mainly by its ambiguous spatiality, in-between the illusionistic depth of traditional art and the flatness of modern painting, becoming one of the defining aspects of Guignard’s production.

Our approach does not intend to be chronological. Rather, it seeks to explain how, throughout his career, many aesthetic elements are repeated until they reach a high level of synthesis in landscape paintings dated from early 1950s until the end of his life. Firstly, we investigate the early critical reception of Guignard's oeuvre, still marked by a strong nationalistic interpretation, in order to highlight its defining characteristics, despite of its subject. Thereafter we examine his training period in Europe aiming to clarify possible relationships between his work and the artistic production of that time. We also point out the poetic dialogues he establishes with relevant issues of the Brazilian artistic milieu of the 1930s and 1940s, especially the revaluation of popular imagery. From our point of view, his landscape painting respond in a dialectical way to the peculiar dynamics of Modernism in Brazil, establishing themselves as privileged moments for its understanding.
\end{abstract}

Keywords: Alberto da Veiga Guignard; modern art; artistic tradition; popular culture; space; landscape painting; Brazilian Modernism 


\section{SUMÁRIO}

$\begin{array}{ll}\text { INTRODUÇÃO } & 11\end{array}$

CAPÍTULO 1

AlBERTO DA VEIgA GUIGNARD: O LÍRICO NACIONALISTA

CAPÍTULO 2

A QUESTÃO DA MODERNIDADE E DA RUPTURA

$\begin{array}{ll}\text { CONSIDERAÇÕES FINAIS } & 101\end{array}$

$\begin{array}{ll}\text { ANEXOS } & 105\end{array}$

$\begin{array}{ll}\text { BIBLIOGRAFIA } & 118\end{array}$ 


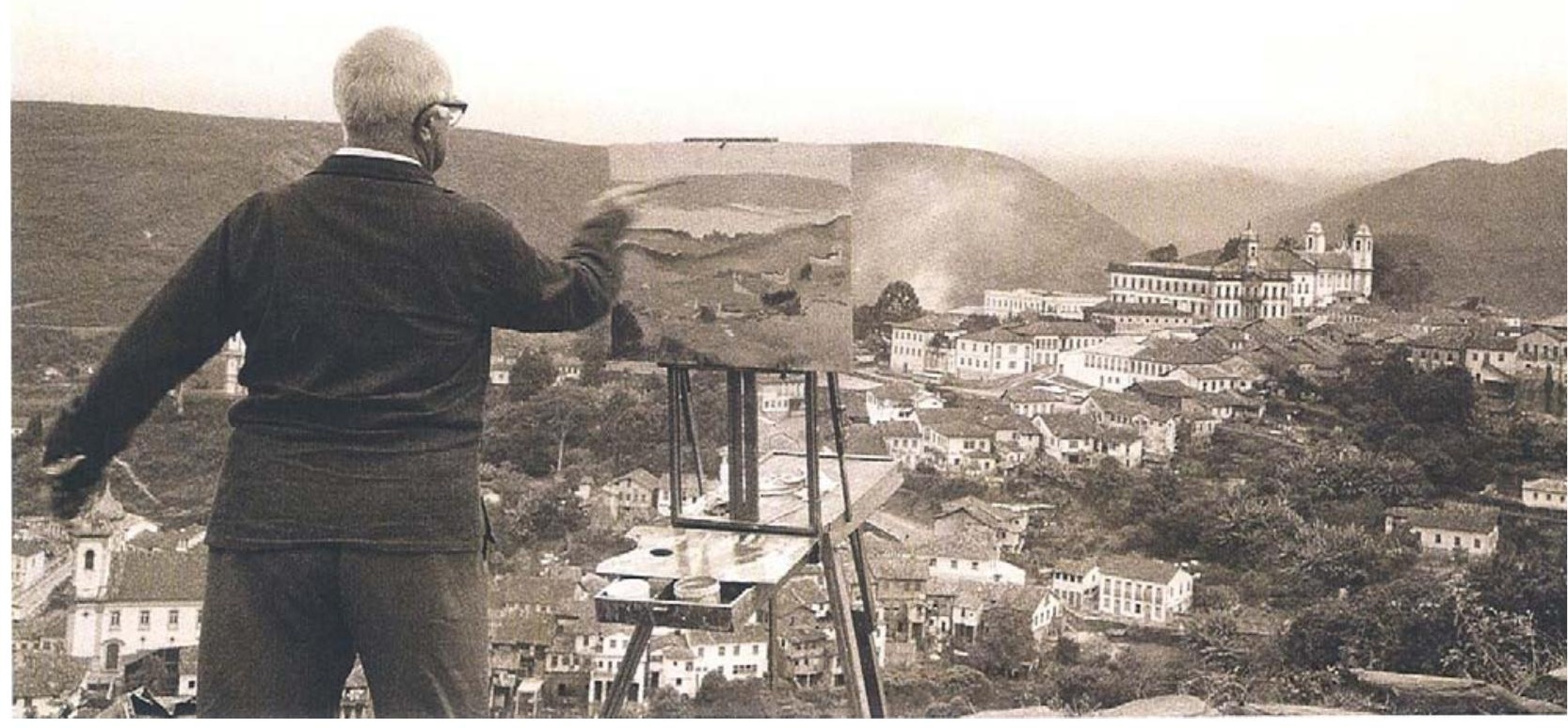




\section{INTRODUÇÃO}

Reconhecido como um dos mais importantes artistas modernos em atividade no Brasil na primeira metade do século 20, Alberto da Veiga Guignard (1896-1962) se destacou principalmente por suas paisagens montanhosas de tom lírico que aludem às noites de festa de São João, e que foram pintadas em sua maioria nos seus dez últimos anos de vida. Artista de formação européia, Guignard se fixa no Rio de Janeiro em 1929, quando as primeiras manifestações a favor da arte moderna já tinham ocorrido. No entanto, na capital federal da República o sistema acadêmico dominava o ensino e a circulação da arte, com os salões oficias. Sua obra se desenvolve de modo concomitante ao chamado período de institucionalização e "rotinização" das linguagens modernas que se daria nas duas décadas subseqüentes, momento em que se condensam as discussões em torno do nacionalismo, da identidade brasileira de nossa arte moderna e de seu papel social.

Entretanto, são muitas as ambigüidades e paradoxos que cercam a obra de Guignard. Em primeiro lugar, a aparência de simplicidade ingênua que sugerem muitos de seus trabalhos - e que é reiterada pela remissão a dados biográficos - mas que num segundo momento se revela como uma busca expressiva mediante elementos bastante característicos que explicitam seu diálogo com toda uma tradição artística para além da pura espontaneidade ou de uma visão simplesmente instintiva. 
No âmbito de sua personalidade, se por um lado é certo que o próprio artista age de maneira tal para que fosse visto como uma espécie de bom selvagem com alma de criança, é evidente que seu apreço pela vida boêmia, o descontrole do vício que às vezes o levava a trocar quadros por um copo de bebida e que com certeza minou sua saúde e sua capacidade de produzir (colocando-o no final da vida no centro de uma polêmica nacional), são constituintes do mesmo homem. Trata-se desse lado torturado (e socialmente “indesejável”) do comportamento do artista, como notou Rodrigo Naves ainda demora a vir à tona ${ }^{1}$, que curiosamente se revela mais explicitamente nos trabalhos expressionistas de temática religiosa, e que de certa forma irá marcar suas paisagens mais diluídas (e dilaceradas) realizadas nos últimos anos de vida.

No que diz respeito à periodização de sua produção, dificilmente conseguiríamos aplicar à trajetória de Guignard um modelo evolucionista, segundo uma divisão de “fases”, pelas quais seria possível rastrear influências pontuais a indicar uma sucessão paulatina ou um movimento unidirecional de superação. Ao contrário, ela é pontuada por altos e baixos, avanços e recuos, por vezes inexplicáveis e que desnorteiam o pesquisador.

Toma-se, por exemplo, duas pinturas produzidas no mesmo ano, 1959, Tarde de São João [fig. 1] e Ouro Preto [fig.2]. Elas são radicalmente distintas no tratamento que ele dá ao espaço e às figuras. A última assume um partido mais convencional, mesmo que à maneira pós-impressionista, onde a perspectiva e o traço servem basicamente para construir a arquitetura na paisagem. Estamos diante de um estilo naturalista modernizado, que nada tem de original.

\footnotetext{
${ }^{1}$ Cf. Rodrigo NAVES, “A maldade em Guignard”, in: Guignard: uma seleção da obra do
} artista, p. 11-14. 
Por sua vez, a pintura Tarde de São João pode ser considerada como uma das mais representativas do "estilo Guignard”. Trata-se de uma paisagem de dimensões medianas pintada a óleo sobre madeira (um dos suportes mais utilizados pelo artista), cuja construção espacial sugere uma mescla de intimismo e distância, em que não há expansão para além dos limites do quadro, apesar do artista utilizar sabiamente o formato do suporte.

Esta pintura se caracteriza por uma profundidade rasa, em que a aproximação ou a passagem entre os vários planos se dá pela sobreposição escalonada de massas coloridas transparentes em camadas horizontais distribuídas de maneira cadenciada sobre um fundo claro de luz amarela, cuja evidência contribui para unificação do plano geral da pintura e sua impressão de translucidez. Essa disposição é responsável pela suave vibração luminosa que domina o quadro.

A paleta do artista, que aqui surge completa em suas cores, é espalhada de maneira harmônica por toda superfície. Nota-se que elas se fazem simultaneamente presentes em níveis diversos do espaço (por exemplo, o lilás bem rente à base e no alto), reforçando a sensação de indefinição espacial com relação a uma ordem realista da paisagem, posto que tudo parece ao mesmo tempo chão, montanha e nuvem. No fim, o que parece ser uma perspectiva aérea e distanciada se funde à proximidade da perspectiva frontal.

Seu ritmo é marcado pela existência dessas figuras (balões, igrejas, grupos de pessoas, árvores, mastros etc) em escala diminuta. Elas insinuam uma leitura de baixo para cima, elevando-se de maneira cadenciada e sinuosa, num evidente movimento ascensional. Ao mesmo tempo em que organizam delicadamente esse mundo, no sentido de dar alguma realidade reconhecível à massa colorida, localizando assim o observador, a fragilidade do 
desenho as transformam em signos dúbios de materialidade etérea. A qualidade incandescente de alguns de seus tons, como o próprio amarelo, o roxo e o verde, além do branco, fazem delas pontos irradiadores de luz a pulsar (e pontuar) no espaço².

Diante desta Tarde de São João somos confrontados com aquela experiência ambígua entre proximidade e distância que singularizam muitos dos trabalhos de Guignard. Do ponto de vista espaço-temporal, a imagem se localiza em um lugar intermediário entre a memória e o esquecimento, o presente e o passado, a realidade e o sonho: uma experiência da qual nos lembramos, mas que parece indeterminada, pelo menos segundo uma noção histórico-cronológica. Ao que corresponde sua indefinição ontológica: a paisagem não é “abstrata” a ponto de transfigurar completamente o mundo real, mas tampouco se trata de uma representação realista de um local específico. Em sua qualidade sintética, sugere-se um estado limiar de evocação.

Entretanto, se voltarmos às paisagens realizadas na década de 1940, que se distinguem pela horizontalidade da composição, pela densidade da matéria pictórica e por um uso mais naturalista das cores (e que em geral trazem como assunto locais “identificáveis”, como o Jardim Botânico, a Serra do Mar ou o Parque Municipal de Belo Horizonte) também já se faz evidente a constituição dialética entre proximidade e distância, a combinação entre a percepção do dado real com uma espécie de segredo e encanto. Como notou o crítico de arte Mário Pedrosa, nestas telas podemos reconhecer o artista submetido inteiramente à natureza, contudo "os cinzas escuros aprofundam a densidade da matéria, e

${ }^{2}$ Essa qualidade incandescente ou cintilante de algumas cores de Guignard é bastante evidenciada na série Via Sacra pintada em 1960 ou nas Noites de São João também realizadas neste período, onde os fundos escuros, mais diluídos e monocromáticos (p.ex. Noite de São João, 1961 da Coleção Roberto Marinho), são pontuados por essas pequenas figuras de luz. 
abrem fendas, numa sugestão de espaço interior por onde circulam uma vida misteriosa e sombras circulares"3.

Logo, o que uma primeira análise do conjunto da obra revela, é que seria quase impossível identificar em seu interior períodos marcados de guinada radical. O estilo de Guignard sugere antes um movimento lento de constituição de uma poética própria que parece seguir um processo pendular de depuração e condensação, por meio do qual são constantemente reelaborados elementos espalhados ao longo do trabalho, muitos dos quais presentes desde o início de sua trajetória. É como se buscasse uma espécie de intimidade amorosa com aquilo que lhe inspira e interessa, seja a lembrança dos singelos balõezinhos a dançar nos céus coloridos das noites de São João, seja a pintura dos artistas renascentistas que tanto admirava como Leonardo da Vinci e Sandro Botticelli.

Neste sentido, pode-se dizer que seu fazer baseia-se na idéia de acúmulo de experiência, ou na noção de experiência como acúmulo, mediante a qual a observação do artista atinge uma conjunção de afinidades entre "a alma, o olho e a mão”, como tão bem definiu Paul Valéry a natureza da criação artística ${ }^{4}$. Em retrospecto, sua produção recoloca a noção de dilatação temporal que caracteriza tanto o trabalho manual quanto o ritmo das transformações no mundo natural, numa evidente contraposição ao tempo abreviado imposto pela modernidade.

\footnotetext{
${ }^{3}$ Mário PEDROSA, p. 204.
}

${ }^{4}$ Apud. Walter BENJAMIN, “O Narrador”, in: Obras escolhidas - I, p. 220, no qual ele retoma o pensamento de Valéry para explicitar a natureza temporal da narrativa e que me parece ideal para caracterizar a prática de Guignard: “A observação do artista pode atingir uma profundidade quase mística. Os objetos iluminados perdem os seus nomes: sombras e claridades formam sistemas e problemas particulares que não dependem de nenhuma ciência, que não aludem a nenhuma prática, mas que recebem toda a sua existência e todo o seu valor de certas afinidades singulares entre a alma, o olho e a mão de uma pessoa nascida para surpreender tais afinidades em si mesmo, e para as produzir". 
A primeira fase de recepção crítica do trabalho de Guignard é marcada pela oposição àquele que seria, durante o Estado Novo, eleito como o pintor oficial do Brasil: Candido Portinari. Com uma linguagem de viés clássico-realista com controladas deformações expressivas, Portinari transforma-se no modelo de artista moderno brasileiro, pelo menos para o grupo ligado ao Ministério de Gustavo Capanema. Assim, diante da imagem do brasileiro forte, trabalhador, ligado a terra, criada por Portinari, Guignard iria preferir retratar a "alma” do povo simples, os tipos populares que nunca estão trabalhando, as festas e a paisagem bucólica do interior do Brasil. Com ele nasceria, segundo o crítico Lourival Gomes Machado em seu ensaio Retrato da arte moderna do Brasil (1945), o “lirismo nacionalista” como um passo legítimo da segunda fase do modernismo brasileiro.

Vale notar que com essa contraposição, que acarreta evidentemente diferentes tendências artísticas, abarcam-se os dois lados da mesma “identidade nacional”. Na verdade, mais do que em oposição, esses dois pontos de vista sobre a arte brasileira são complementares naquele momento. Por um lado, Portinari expressa a identidade histórica e social, ao passo que Guignard sua dimensão subjetiva. E com esses dois pólos seria desenhado o "Brasil estético", como observou o crítico Ronaldo Brito 5 .

Essa poética subjetivista seria rapidamente identificada com uma bondade natural inspirada pela verdadeira "alma” do brasileiro simples, e que carregada de ingenuidade e inocência, funcionaria como uma reserva moral do país. Essa leitura se confundiria diversas vezes com os traços biográficos do próprio artista, sempre descrito por seus

\footnotetext{
${ }^{5}$ Cf. Ronaldo BRITO, “Só olhar”, in: Experiência crítica, p. 155.
} 
contemporâneos como um “anjo de bondade”, “um santo”, “uma criança adulta”, incapaz de qualquer ato de maldade ou mesquinhez. E assim se resolveria o lirismo de Guignard.

Apesar de ainda persistirem esses juízos em mostras e estudos recentes, é evidente que nos últimos anos, e sobretudo a partir da década de 1980, a crítica de arte brasileira tem procurado rever essa interpretação, ora problematizando-a, ora tentando compreender seu sentido no interior de um panorama mais complexo no qual a formação da modernidade no Brasil seria caracterizada por movimentos de avanço e recuo, quase sempre em descompasso com sua matriz européia (pelo menos até os anos 1950).

Com isso, passa-se a discutir a modernidade singular de Guignard $^{6}$ e sua resignificação histórica no âmbito da arte brasileira. Por um lado, alguns críticos apontaram como sua obra não poderia ser considerada moderna "no sentido rigoroso do termo”. É o caso, por exemplo, da leitura seminal de Ronaldo Brito no já citado ensaio “Só olhar”. Segundo ele, o artista usa a liberdade moderna "um pouco à antiga”, na medida em que algumas características formais de sua pintura reatam com uma tradição que o impressionismo deixara para trás como, por exemplo, a conotação atmosférica de suas cores e a impregnação afetiva do assunto no próprio processo pictórico. Por outro lado, acredita que dentro do panorama do modernismo brasileiro, seu colorismo aponta para uma emancipação da pintura do "peso das velaturas e vernizes acadêmicos”, pois em suas cores

${ }^{6}$ Salvo engano, o marco desta guinada receptiva foi o estudo realizado no Curso de Especialização em História da Arte no Brasil da PUC-RJ sob a coordenação de Carlos Zílio e que originou a mostra e o catálogo A modernidade em Guignard (1982). 
“tênues e alusivas” já podemos vislumbrar “uma preocupação consigo mesmas enquanto relações puras" que não responderiam mais a "finalidades externas aos quadros" 7 .

Já para Carlos Zílio ${ }^{8}$, a "brasilidade” da obra do artista nada teria a ver com o nacionalismo vigente, na medida em que tem origem a partir de um projeto poético que estabelece uma relação intensa com o modelo, e gera "uma apreensão aguda do homem e da paisagem brasileiros”. Sua trajetória seria permeada por uma série de tensões em seu processo de assimilação da modernidade, e que se manifestariam nas diversas soluções dadas, algumas mais ousadas, outras mais convencionais, ao "conflito entre o desenho e a cor”.

Segundo o crítico de arte Rodrigo Naves, uma parte das contradições dessa obra se materializaria de certa maneira naquilo que ela produziu de mais original: sua espacialidade. Longe de querer retornar à concepção tradicional do espaço pictórico, Guignard também parece passar ao largo do espaço gerado segundo a rearticulação de planos fragmentados que foi estabelecida pelo Cubismo, em que a continuidade entre figura e fundo se dá partir de uma trama de relações. No seu caso, a identidade do espaço seria expressa por um movimento que tende a enfraquecer ou dissolver os limites das coisas, criando "unidades sem mediações, continuidades que ocultam sua costura"9.

Para a crítica e historiadora Sônia Salzstein, a trajetória de Guignard será cunhada por “um misto de conservadorismo e renovação que marcam uma vida cultural precária, debatendo-se sob o fardo acadêmico e a letargia paroquial, mas afinal tentando consolidar

\footnotetext{
${ }^{7}$ Cf. Ronaldo BRITO, idem, p. 157-158.

${ }^{8}$ Carlos ZÍLIO, “Com a cabeça nas nuvens”, in: A Modernidade em Guignard, p. 18-21.

${ }^{9}$ Rodrigo NAVES, A forma difícil, p. 132-133.
} 
sua própria experiência moderna” ${ }^{10}$. Sua modernidade surgiria “a posteriori” a partir de exigências internas à própria obra e passaria ao largo de um aprendizado e adoção de uma linguagem ou repertório "que se enfeixava sob a rubrica 'moderno"”. Neste sentido, ela estabeleceria um importante "ponto de vista a distância”, no qual está em jogo a evidência da experiência da própria visão, em seus limites e abrangência. E com isso, “a especificidade não decorre, pois, de uma 'temática brasileira', mas da maneira original com que essa temática se infunde de potência constituinte na obra do artista”. ${ }^{11}$

Essas leituras marcariam o que seria uma "segunda recepção crítica” da obra de Guignard. De certa maneira, elas buscam enxergar, para além da questão nacionalista, a singularidade da modernidade que a caracterizaria, e que de resto não estaria apenas nesta produção, mas também em outros artistas do segundo modernismo brasileiro, particularmente naqueles que começam a produzir entre os anos 1930-40. Há o reconhecimento de uma dinâmica própria da arte brasileira que encontra suas razões em questões de formação social e política, ou ainda, em entraves do próprio meio artístico que apenas lentamente consegue se modernizar em termos de um sistema de arte que funcione para além da Academia e do mecenato oficial.

E se é certo que para cada um dos críticos supracitados os aspectos paradoxais da obra de Guignard terão um sentido específico, essas argumentações coincidem naquilo que apontam em seus trabalhos como a ausência de uma dimensão reflexiva mais forte, daquela autoconsciência crítica que caracterizaria a pintura moderna em seus lances mais radicais.

\footnotetext{
${ }^{10}$ Sônia SALZSTEIN, A questão moderna: impasses e perspectivas na arte brasileira, 1910 a 1950, p. 65.

${ }^{11}$ Sônia SALZSTEIN, “Um ponto de vista singular”, in: Guignard: uma seleção da obra do artista, p. 19.
} 
O que não significaria, contudo, menosprezar a experiência que lhe é própria, em sua flutuação num espaço que não é nem propriamente plano, nem ilusionista; ou ainda em sua relação ambivalente com a tradição.

De modo geral, tendemos a concordar com essas leituras que abrem a possibilidade de outra interpretação do trabalho de Guignard para além de seu pathos nacionalista. Pois de fato, uma primeira visada geral de sua produção revela um procedimento complexo de formalização que não se dá simplesmente por meio de embates ou rupturas. Seus trabalhos sugerem uma assimilação gradual da linguagem moderna, produzindo assim uma obra na qual parecem se mesclar duas temporalidades, dois espaços, um ainda ligado à tradição e o outro decididamente moderno. Ou, em outras palavras, uma modernidade que é construída por uma via de mão dupla, em que não se nega o passado, mas se procura atualizá-lo, no sentido mais potente da palavra.

Pois sempre me chamou a atenção o modo como Guignard parecia combinar em suas pinturas elementos díspares. E esses se manifestam, por fim, em diversos níveis: do ponto de vista formal, o tratamento diverso que dá entre a figura e o fundo em suas telas, fazendo conviver o linearismo delicado do desenho com a indefinição e volubilidade sugerida pela sobreposição de manchas de cores diluídas; a sugestão de infinito, mas sem recorrer à perspectiva tradicional; um movimento dúbio entre a verticalidade do espaço que sugere planaridade e exteriorização e uma tendência à introspecção; a tomada de um ponto de vista que remete à busca por uma totalidade inteligível e ao mesmo tempo sua negação na apresentação de um mundo desfocado, cuja falta de nitidez sugere a eminência de sua modificação, e que só poderia ser parcialmente reconstituído por meio de pequenos 
detalhes. Além disso, há o estranhamento entre uma técnica refinada que remete à tradição da pintura ocidental e sua aparente naïveté.

Esta tese busca compreender o amálgama singular que define a obra de Guignard. No primeiro capítulo, retoma-se a leitura crítica de época a fim de definir alguns traços formais que já indicariam a singularidade de sua linguagem para além de sua temática. Ao mesmo tempo, uma análise histórica mais cuidadosa nos mostra também o quanto sua obra possui em comum com a arte de seu tempo. Por isso, retomamos seu momento de formação na Europa também com a intenção de desfazer alguns mal-entendidos e de certo maneira indicar suas possíveis filiações artísticas. Trata-se de retomar os dados históricos mediante pesquisas que realizamos recentemente em Munique, na Alemanha. Os mais de vinte anos que Guignard permaneceu fora do Brasil ainda hoje são fonte de engano e mistificação. Acreditamos que na medida em que conseguirmos esclarecer, partindo também de alguns trabalhos realizados antes de 1929, o ambiente artístico no qual ele conviveu (e onde diversas tendências se cruzavam como o simbolismo, o pós-impressionismo, a abstração, o expressionismo e o movimento geral de "volta à ordem”), estaremos mais aptos a entender suas escolhas estéticas.

Por um lado, ao se fixar definitivamente no país em 1929, Guignard já tinha uma concepção particular de arte, mesmo que está não fosse teorizada. E é através dela que ele vai “descobrir” a nova realidade que se apresentava. O que não significa a ausência de diálogo com o ambiente artístico e as questões que estavam na ordem do dia, como a valorização da cultura popular. 
Por fim, poder-se-ia afirmar que a originalidade de seu trabalho reside, sobretudo, na configuração de sua espacialidade pictórica, que como vimos, em seus melhores momentos, consegue reunir elementos dessemelhantes em um todo orgânico, mas sem que esta harmonia não deixe de provocar estranhamento. Cabe ressaltar que apesar da qualidade excepcional de seus retratos, é neste gênero que ele parece realizar por completo sua noção própria de espacialidade moderna. E apesar de não haver propriamente uma “evolução” em seu trabalho, há uma lenta modificação que nos leva às suas paisagens fantásticas dos últimos dez anos de vida e que se destacam por expressarem um tom mais soturno. Como interpretar essa última produção não apenas dentro do contexto de sua obra, mas também tendo em vista as mudanças que a arte sofria desde meados do século passado? Podemos ver nisso um movimento de auto-reflexão sobre uma experiência-limite da representação?

Desta forma, não é nosso intuito seguir um percurso cronológico da obra do artista. Igualmente, pela própria dificuldade de acesso que o conjunto da produção de Guignard apresenta ainda hoje para o pesquisador interessado em estudá-la, seria impossível realizar um levantamento exaustivo de seus trabalhos dentro dos limites de uma pesquisa acadêmica. No entanto, acreditamos que com os recortes sugeridos para análise podemos abarcar suas principais características, esperando trazer à tona novos elementos para sua compreensão e da arte moderna brasileira em geral. 


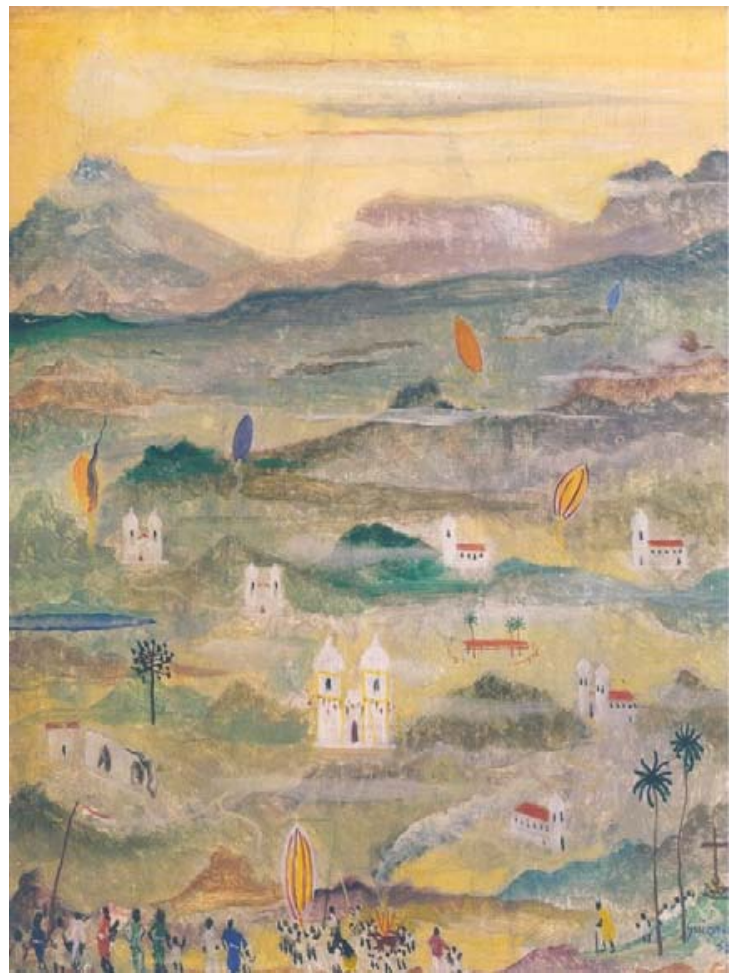

FIG.1 - TARDE DE SÃO JOÃO, 1959 (ÓLEO SOBRE MADEIRA, 38,5 X 39 CM).

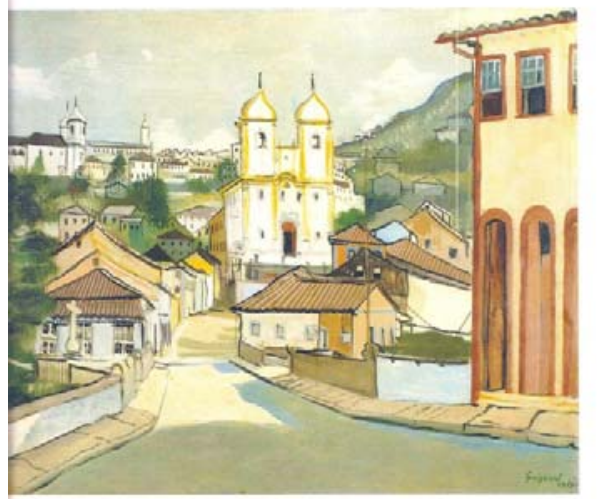

FIG.2 OURO PRETO, 1959 


\section{CAPÍTULO 1}

\section{AlBERTO DA Veiga GUIGNARD: O LÍRICO NACIONALISTA}

Uma das primeiras tentativas de compreensão do papel desempenhado pelo artista Alberto da Veiga Guignard no contexto da história da arte brasileira foi empreendida, salvo engano, pelo crítico de arte paraibano Ruben Navarra em 1943, no ensaio "Iniciação à Pintura Brasileira Contemporânea”, escrito originalmente para ser publicado como apresentação da mostra de pintura moderna brasileira na Royal Academy of Art em Londres, em benefício da RAF (Royal Air Force) em 1944. Neste texto Navarra disserta sobre as origens e o desenvolvimento da arte moderna no Brasil, num momento em que ela, na sua opinião, parecia finalmente ter se estabelecido no país ${ }^{12}$. Após comentar rapidamente o trabalho de Anita Malfatti, Tarsila do Amaral, Lasar Segall e Di Cavalcanti (os modernistas da primeira fase), dedica um parágrafo inteiro a Guignard, que transcrevemos a seguir:

${ }^{12}$ Segundo sua argumentação, “a existência incontestável de uma 'atmosfera brasileira’ em nossa pintura moderna - algo que nos fala da terra, do povo, da tradição humana, do cenário social, das luzes e cores dos trópicos - isto já nos dá direito a considerar a existência de uma 'pintura brasileira'”. (Ruben NAVARRA, in: Modernidade negociada: um recorte da arte brasileira nos anos 1940, p. 91). 
“Quando já tinham serenado as barricadas dos paulistas, Alberto da Veiga Guignard voltou da sua longa estadia na Europa, em cujas escolas de arte decorreu toda a sua juventude. Pois bem, Guignard que é dos pintores brasileiros o que recebeu mais longe formação européia, é justamente um dos representantes mais autênticos do espírito regional da pintura brasileira. Dono de uma técnica apuradíssima nos anos de estudo na Europa, ele é, todavia, a negação do espírito de virtuosismo. Há na sua pintura uma espécie de ingenuidade que não vem da deficiência de técnica, mas do sentimento com que contempla a paisagem nativa, sobretudo a das velhas cidades de fisionomia colonial. Ele nos transporta evidentemente ao âmago do Brasil, e sua pintura tem uma nota enormemente enternecedora e íntima, cujo segredo é perceptível a qualquer coração brasileiro. Esse grande lírico é o primeiro nome de importância que encontramos na fase que poderíamos chamar de ‘post-modernismo’, indicando um caminho já consolidado”.

O comentário de Navarra ecoa, e ao mesmo tempo circunscreve, algumas das chaves interpretativas que iriam marcar a recepção crítica da obra de Guignard até hoje. O autor, assim como a maior parte dos partidários do modernismo, acreditava, na década de 1940, que a batalha contra os acadêmicos finalmente havia sido ganha. Sendo assim, o momento se mostrava oportuno à reconstrução histórica e teórica da arte moderna brasileira $^{13}$. Já em 1942, em sua famosa conferência “O Movimento Modernista”, Mário de Andrade desempenharia papel pioneiro nessa tarefa ao estabelecer uma divisão entre a fase

${ }^{13}$ Contudo vale lembrar que foi exatamente em outubro de 1943 que a exposição do grupo de alunos de Guignard (batizado por Manuel Bandeira de "A Nova Flor do Abacate") no Diretório Acadêmico da ENBA foi atacada por alunos de tendência acadêmica. O episódio causou comoção no meio cultural e o grupo teve o apoio público de diversos intelectuais. Maria de Lourdes Pires da Rocha, que assinava uma coluna sobre artes plásticas com o pseudônimo de Raul de São Victor no jornal A Manhã, aproveita o episódio para defender a necessidade de criação de um museu de arte moderna, inclusive com a tarefa de se fazer uma seleção entre os modernistas (Cf. Raul de São VICTOR. "Um museu para a arte moderna”). 
na qual predominava um "espírito destruidor" no movimento e que teria tido seu marco inicial com a Semana de Arte Moderna de 1922 e sintomaticamente duraria até 1930; e finalmente desta data em diante, a fase “construidora”, na qual ocorreria a realização plena e aceitação pública das "três normas” impostas pelo modernismo ao meio cultural: “o direito permanente à pesquisa estética; a atualização da inteligência artística brasileira; e a estabilização de uma consciência criadora nacional”14.

Ao se referir textualmente a Mário de Andrade, o crítico paraibano partilha de sua análise, afirmando que “em 1922, a arte moderna, grito de uma nova geração que hoje está entre os 40 e os 50, foi espetacularmente 'reconhecida' pelo que de melhor representava então a juventude criadora nas letras e nas artes do Brasil. Hoje essa juventude amadureceu, praticamente não há a necessidade de empregar a palavra 'moderno' com o sentido de exceção e revolução que tinha naquele tempo. Hoje, as posições inverteram-se e é o homem acadêmico que parece uma criatura de exceção, exótica e estranha a seu tempo”15.

Do ponto de vista histórico, seria nessa fase de consolidação, também denominada "post-modernista”, que Guignard desempenharia um papel de destaque. Como os autores nos fazem entrever, esse não seria mais um momento marcado pelo espírito "festivo" e de ruptura dos primeiros modernistas, mas antes por uma atitude formativa de pesquisa e construção. Segundo os críticos, já havia se formado uma tradição moderna no país, a qual Guignard se insere um pouco tardiamente, ou seja, sem ter participado propriamente de suas origens ou definição. O que parece sugerir também a trajetória isolada (em relação a

${ }^{14}$ Ao que Mário acrescenta: "Nada disto representa exatamente uma inovação e de tudo encontramos exemplos na história artística do país. A novidade fundamental, imposta pelo movimento, foi a conjugação dessas três normas num todo orgânico da consciência coletiva". (Mário de ANDRADE, “O movimento modernista”, in: Mestres do modernismo, p. 244).

${ }^{15}$ NAVARRA, op.cit., p. 89. 
grupos ou artistas) que seguiria no Brasil, apesar de sua produção, neste momento, coadunar com as posições modernistas ${ }^{16}$.

Mas o que há de moderno em Guignard segundo essa interpretação? Por um lado, seu regionalismo. Segundo Navarra, a singularidade da arte moderna brasileira é dada fundamentalmente por seu caráter regional: “enquanto a pintura acadêmica brasileira é cem por cento européia, a nossa pintura moderna anti-acadêmica logo soube abrir os olhos para a contemplação amorosamente lírica do nosso mundo regional”. Logo, um dos pontos principais do programa do movimento moderno teria sido a redescoberta do Brasil nativo, “escondido por trás da cortina acadêmica do Brasil convencional e fictício”. Por outro, o que se destaca no caso de Guignard é que ele teria conseguido equilibrar seus profundos conhecimentos técnicos com uma ingenuidade de sentimento diante da paisagem e da realidade brasileiras (alcançando, enfim, aquele equilíbrio entre nacionalismo e internacionalismo tão almejado pelos modernistas da primeira geração).

Dentro deste quadro, seu regionalismo teria algo de sentimental, marcado pelo enternecimento e pelo intimismo, e falaria não à consciência crítica, mas ao coração. Como outros críticos da época, Navarra utiliza freqüentemente a expressão "pintor-poeta” para se

${ }^{16}$ Curioso notar que Guignard é um dos poucos artistas citados por Mário de Andrade em seu texto, que de resto assume um tom confessional, de alguém que foi um dos protagonistas do movimento modernista. A certa altura, comentando a conquista da liberdade (estética) e independência dos artistas na época, que por isso não poderiam imaginar o que teriam passado os modernistas da Semana, ele pergunta: "Quem se revolta mais, quem briga mais contra o politonalismo de um Lourenço Fernandes, contra a arquitetura do Ministério da Educação, contra os versos ‘incompreensíveis' de um Murilo Mendes, contra o personalismo de um Guignard?... Tudo isto são hoje manifestações normais, discutíveis sempre, mas que não causam o menor escândalo público” (p. 251). Tendo em vista a conclusão do texto de Mário, que é marcado o tempo todo pela questão da luta contra a ditadura, e que em um movimento de autocrítica afirma que os modernistas não teriam, apesar de tudo, contribuído para um melhoramento político-social do homem, exigindo que eles enfim aprendam a "marchar com as multidões", o adjetivo personalista parece ter também um tom reprovador... 
referir aos artistas modernos e particularmente a Guignard. Com isso, ele sinaliza outra discussão importante para a cultura artística da época: a diferença entre o artista e o artesão. Dizer que um pintor é um poeta significa afirmar, no seu caso, que ele não apenas domina o seu ofício em termos artesanais, mas como um poeta "muda a escala da experiência, transforma a ótica em poética”17, ou seja, vai além de uma visão puramente objetiva do mundo. Não deixa de ser intrigante, naquele momento, que no Brasil se valorizasse o componente lírico como atributo do verdadeiro artista plástico ${ }^{18}$.

Mário de Andrade, em 1937, já falava da particular “intimidade” que Guignard gozava com a natureza, como se ele pudesse sentir de maneira mais secreta e verdadeira tudo o que pintasse ou desenhasse. E por isso, nele nada perderia o lirismo ${ }^{19}$. Esse olhar lírico, que aqui já aparece associado a uma espécie de ingenuidade, vai ressoar na interpretação crítica da obra de Guignard ainda hoje.

Em 1945, o crítico de arte e historiador Lourival Gomes Machado irá cunhar, no livro Retrato da arte moderna do Brasil, a expressão "lirismo nacionalista” para definir a poética guignardiana em contraponto à estética nacionalista de Candido Portinari, que para

${ }^{17}$ Ruben NAVARRA, op. cit, p. 86.

${ }^{18}$ Carlos DRUMMOND de ANDRADE escreverá sobre Guignard logo após sua morte em 1962: "Chamei-o poeta, e se fez algum verso não deve ter sido significante. Nem foi precisamente porque pintasse assuntos poéticos. Mas porque a sensação que me dá em conjunto sua pintura é de uma organização poética de ritmos requintados e específicos da poesia. Nunca, para meu gosto, poesia e pintura se fundiram tanto na arte brasileira como nas telas de Guignard, em que a visão lírica do artista não é um elemento voluntário e adicional, mas a determinante da concepção. Pintura e desenho de Guignard produzem-nos a euforia do conhecimento poético das coisas, refiguradas; mais do que transfiguradas, pois não perderam a realidade mas revelaram seus traços íntimos, sua tessitura sensível, ao mesmo tempo que sugerem uma forma de poema legível através dos valores plásticos. Era a poesia que ele carregava em si e que o embalou a vida toda, fazendo-o viver ao mesmo tempo em dois mundos distintos” (apud. A Modernidade em Guignard, p. 116).

19 Depoimento de Mário de Andrade reproduzido no catálogo da mostra "Guignard" realizada em 1942 no Diretório Acadêmico da Escola Nacional de Belas-Artes, Rio de Janeiro (Arquivo Projeto Guignard, PUC, Rio). 
ele buscava exprimir o Brasil em termos de epopéia. A comparação entre os dois artistas ocorre porque para o crítico eles seriam os dois mestres-fundadores do que chamaria de "Escola do Rio”20, que nasce a partir da atuação de Portinari e Guignard como professores de pintura e desenho, respectivamente, na Universidade do Distrito Federal nos anos 1930. Machado acredita que Guignard tem uma visão do homem brasileiro como um ser de "bondade e candura”, o que o aproximaria ao romantismo, enquanto para Portinari o brasileiro é, em uma visão mais “condoreira”, um forte. Com isso, definem-se os dois pólos do nacionalismo nas artes plásticas ${ }^{21}$.

Segue então sua análise de Guignard:

“Alberto da Veiga Guignard cresceu praticamente na Europa. Trazia, ao voltar homem feito ao Brasil, uma bagagem de erudição que, com prodigioso equilíbrio, não permitiu que prejudicasse sua fase de adaptação. Procurou recuar para o campo da técnica a sabedoria adquirida lá fora e penetrou no mais íntimo do brasileirismo de assunto e de sentimento. Os seus grupos de tipos populares - a 'Família do fuzileiro

${ }^{20}$ Para Machado, a segunda fase do movimento modernista brasileiro (após 1930), caracterizada como um momento de expansão, pode ser organizada em termos de "escolas" com estilos bem definidos e diversos. Entretanto, em seu estudo, estas se resumiriam basicamente a duas: a do Rio (cidade à qual afluíam artistas de diversas regiões do país, principalmente do nordeste) e a de São Paulo. Cf. Lourival G. MACHADO, Retrato da arte moderna no Brasil, p. 63.

${ }^{21}$ A partir dos anos 1980, a crítica de arte brasileira iniciaria uma revisão desses pressupostos instituídos pelos críticos nacionalistas sobre a arte moderna brasileira. Neste sentido, parece-me fundamental, para o estudo de Guignard, o ensaio de Ronaldo Brito "Só olhar", publicado em 1983 como parte do projeto “A modernidade em Guignard” (PUC-Rio). Já no primeiro parágrafo de seu texto, ele retoma o argumento de Machado nos seguintes termos: "A expressão de nossa alma, esta parece ser a idéia vigente de Guignard. Aí estaria, portanto, um dos marcos do modernismo: assim como Portinari representa a identidade histórica e social brasileira, Guignard exprime a dimensão poética subjetiva. Entre esses dois pólos desenhamos ainda hoje o mapa da nossa geografia artística. Um mito objetivo, um mito subjetivo e está pronto o Brasil estético. Existem aí, misturadas, uma verdade e uma mentira”. (Ronaldo BRITO, A modernidade em Guignard, p. 11). 
naval', a 'Família numa praça' - dão-nos uma medida perfeita da pureza do povo e de seu mundo interior de crenças e valores refletidos nessas figuras que posam, como se fosse diante do fotógrafo ambulante, procurando mostrar o quanto valem. Mas pode-se dizer que isso foi apenas uma fase, porque a paisagem logo o atraiu e então são as igrejas, peroladas de lâmpadas de cor e coroadas de rojões e balões, que fazem um deslumbramento humilde que só a pureza é capaz de emprestar tamanho encanto. O seu lirismo nacionalista é passo legítimo da segunda fase do modernismo. E é isso, e é essa devoção a uma pintura de simplicidade franciscana e de alegria joanina que procura transmitir a seus alunos”22.

Para Machado, bem como para Navarra, a singularidade da pintura de Guignard residiria também na temática de sua obra (tipos populares; arquitetura colonial etc) e no "sentimento" com o qual contempla esses assuntos. O brasileirismo de assunto e sentimento, a visão do homem brasileiro como um ser bondoso e puro, seu encanto pela natureza, a pureza do povo, que ao mesmo tempo se confunde com a pureza do olhar do artista são as notas características do lirismo guignardiano e, diga-se de passagem, sua contribuição à arte brasileira moderna.

Ainda nesta década, outro crítico, Mário Pedrosa - que conhecera Guignard na casa de Ismael Nery no início dos anos 30, quando ele acabara de chegar da Europa e trazia consigo, segundo o crítico, “sobretudo uma técnica à cata de motivos” - afirmava em artigo de $1946^{23}$ que "era a poesia, enfim, o que ele (Guignard) encontrava ao saltar no Brasil”, prefácio.

${ }^{22}$ Lourival G. MACHADO, op. cit., p. 64-65. O ensaio foi escrito em 1945, como indica o ${ }^{23}$ Mário PEDROSA, op. cit., p. 203-205. 
em referência a aproximação do artista aos poetas, ao que acrescenta "e dela já vinha ele cheio ... desde que nasceu”.

Pedrosa também associa o artista à fantasia romântica e refere-se novamente à importância que o assunto adquire na produção de Guignard. Entretanto, este não é mais entendido no sentido de um brasileirismo, mas como um interesse mais universal pelo poético, o estranho, o subjetivo e o "super-real". Ele aponta que se primeiramente esse espírito é revelado nas obras fantasiosas e literárias da fase conhecida como "surrealista”, o artista, cansado da “inspiração puramente subjetiva”, vai procurar na natureza, no espetáculo exterior, no mundo das coisas simples, uma inspiração maior de uma vida misteriosa e assim “a poesia se transpõe para fora”.

Nesta mudança, Pedrosa já percebe uma tensão interessante na obra de Guignard entre as "idéias fantásticas e solicitações conceituais” (como um "demônio da anedota interior”) e a visão que se quer sujeita de modo passivo ao mundo exterior. O crítico de arte nota como em meio a paisagens do parque municipal de Belo Horizonte, aparece de relance, como uma alucinação que não chega a tomar forma, figura advinda de um mundo fantástico. Mas conclui que como “um anacoreta no deserto” ele não sucumbe à tentação do fantástico e do poético (aqui talvez como sinônimo de literário), mantendo-se devoto de seu “métier de colorista”.

Neste sentido, o artigo de Pedrosa sobressai por sua ênfase diversa sobre a pintura de Guignard, indicando que naquele momento já havia uma possível modificação de paradigmas no âmbito da própria crítica. Nele já aponta o significado que a paisagem, não apenas como a continuação de um gênero pictórico, mas como um problema moderno, ou 
seja, o problema da natureza e da posição do artista moderno em relação a ele, tem para a constituição da poética guignardiana. Por isso, sua análise formal - que a exceção de alguns artigos de Navarra ${ }^{24}$ e do crítico de arte argentino Jorge Romero Brest ${ }^{25}$, não era corrente na época - recai sobre as paisagens mineiras de Belo Horizonte, Ouro Preto, Sabará e Diamantina, pintadas em meados da década de 40.

${ }^{24}$ Por exemplo, Ruben Navarra escreve sobre as paisagens mineiras em artigo sobre o artista: "Os tons frios e graves, como os da própria luz mineira - cinzas, ocres, terras - que o mestre põe na sua paisagem são bem do maior pintor moderno que já botou os olhos no céu de Minas. É preciso ter vivido aquela atmosfera para perceber quanto o pintor lhe é fiel nas suas notas surdas e tão límpidas de cinza e sujo. Revejo o céu branco, o verde-cinza da pedra-sabão...Só a pintura deste céu é uma obra de mestre pelo espaço e pela matéria. Céu difícil. Nem uma nesga de azul. Os leves toques de verde e roxo na espessa massa dos cinzas produzem a gama que deixa longe a mera sensação de pitoresco.”, apud. Piedade GRINBERG, Ruben Navarra e a crítica de arte na década de 40 no Rio de Janeiro, p. 131.

${ }^{25}$ Jorge Romero BREST faz uma arguta análise formal da obra de Guignard no livro Pintura Brasileña Contemporânea (publicado por ocasião da mostra coletiva de artistas brasileiros organizada por Marques Rebelo em 1945 em Buenos Aires, La Plata e Montevidéu), revelando um grande entusiasmo por seu trabalho: "Devo confessar que um desenho de Guignard - Paquetá - é uma das obras que me impressionaram mais profundamente na mostra. Talvez seja apenas uma reação subjetiva, ainda que depois procurei racionalizá-la, mas certo é que o mundo simplíssimo que criou com linhas me fez sentir com absoluto imediatismo sua profunda mensagem expressiva. Ainda que dissimule uma estrutura racional e pareça primitivo e infantil, o desenho tem grande riqueza de imaginação expressiva; joga Guignard nele com traços de diferente intensidade, recorre a superfícies cheias, valoriza os brancos - sobretudo esse céu que ocupa a maior parte da folha renuncia quase por completo às sombras, e vai escrevendo com uma caligrafia singular, como se tivesse desejado registrar as menores emoções que as coisas produzem, uma frase terna, de esquisita doçura. Nos óleos se agrega a esse elemento emotivo da linha a força espontânea e brilhante da cor, contrastando com maior pujança que nas paisagens de Tarsila e com pastosidade que permite dar qualidade de objeto-volume às figuras, distribuídas segundo um sentido rítmico que é produto de uma maravilhosa alucinação ante as coisas. Mas a cor não se modela em seus quadros nem é expressão íntima de sua rica percepção visual: ainda nos óleos é o traço, trêmulo e aproximativo, o que guia, equilibrando a emoção circunstancial ante as coisas e o mais rigoroso sentido de construção arquitetônica” (Jorge R. BREST, op. cit., p. 21-22). Vale notar que o crítico argentino vê nesta dependência da linha um diferencial da pintura moderna brasileira. Identifica, a partir das obras expostas, uma escola primitivista, na qual insere Guignard e Tarsila do Amaral como parte dos pintores primitivistas não ingênuos, aqueles que "escondem atrás de uma aparência encantadora de um desenho ou de uma pintura primitiva ou infantil uma sabedoria de ofício e um sentido poético de adulto ultracivilizado (...) Não é mera coincidência que sejam os pintores brasileiros que denotam uma assimilação mais profunda dos princípios plásticos europeus de vanguarda ...” (Idem, p. 20). 
Nessas paisagens, que indicariam uma mudança, parece ver de maneira positiva uma possível superação por parte do artista do linearismo (“imaginação linear”). Em sua qualidade puramente pictórica, elas retomariam aquelas realizadas no Jardim Botânico do Rio de Janeiro no final dos anos 1930, se diferenciando pela ausência do traço fino e delineado dos retratos, Festas de São João e paisagens imaginárias.

Em sua interpretação, Pedrosa de certa forma descortina a relação densa e fundamental entre linha e cor presente na produção pictórica de Guignard. Em sua opinião, quando o desenho se faz necessário à composição da paisagem há uma perda de efeitos de irisação cromática e de dramaticidade comovente do conjunto. Pois o diferencial dessa obra residiria na capacidade de se submeter inteiramente “à percepção, à natureza e à paisagem"26.

É evidente que o crítico apresenta um outro olhar sobre a obra de Guignard, distante das preocupações nacionalistas dos outros críticos da época; por isso diante da sutileza com que analisa, dentro dos limites de um artigo de jornal, a construção colorista do artista, o parágrafo final não deixa de ser um pouco decepcionante:

"Poeta e simples criador, sem pretensão. Guignard não tem gosto nem pretensão aos grandes planos arquitetônicos. Com a sabedoria técnica e anônima dos artesãos ele pinta com a alegria das crianças nos brinquedos de roda. Que mais se pode querer?”

26 “Guignard não é um analista, nem um construtor que traça o esboço da paisagem e o leva para arrumação posterior. Ele submete-se inteiramente à percepção, à natureza, à paisagem”. (Mário PEDROSA, op. cit., p. 205). 
Por fim, em 1953, é inaugurada no Museu de Arte Moderna do Rio de Janeiro a primeira retrospectiva de Guignard com 92 trabalhos (o artista tinha 57 anos). A essa altura, ele já era reconhecido como um dos mais importantes artistas modernos brasileiros, apesar do caráter tardio da mostra. Vivendo em Belo Horizonte desde 1944, onde foi convidado pelo então prefeito Juscelino Kubitschek a lecionar um curso livre de desenho e pintura, ele se dedicava quase exclusivamente à paisagem e ao retrato.

O texto de apresentação da exposição foi redigido pela escritora e amiga do artista Lucia Machado de Almeida, e de certa forma não avançava muito nas interpretações realizadas até então. Na verdade, ele assume um tom bastante biográfico, para o qual a convivência íntima com Guignard, que passou diversas temporadas em sua casa, deve ter contribuído. Vale lembrar que daqui para frente, as leituras de cunho biográfico se tornariam cada vez mais recorrentes em relação à obra do artista.

Citando o poeta mineiro Alphonsus de Guimaraens Filho, Lucia Machado refere-se primeiramente a Guignard como o “íntimo do maravilhoso”, para em seguida afirmar que ele talvez fosse o mais intuitivo e puro dos artistas brasileiros, o único capaz de nos transportar às florestas mágicas de Grimm e Perrault e nos colocar em "estado de graça”. Elogia o seu desenho simples de traço fino que como nenhum outro capta "o espírito e a essência das coisas”. E a essa qualidade associa a pureza infantil do homem adulto: 
"Eterna criança grande, Guignard conservou a ingenuidade, o lirismo e a frescura da infância, como se a vida e o tempo por ele tivessem passado impunemente, deixando-o intacto",27.

Não é nossa intenção aqui realizar um levantamento exaustivo da crítica sobre Guignard. O que buscamos é compreender, em linhas gerais, os diversos elementos que estão em jogo e fornecem o enquadramento da primeira recepção crítica da obra nos anos 1940/50, momento em que esta parece alcançar um relativo reconhecimento público. A nosso ver, isto se mostrou necessário, de saída, dada a dificuldade que encontramos de ter um conhecimento direto de sua produção artística, de tão difícil acesso até hoje. Sobretudo no que diz respeito a essas duas décadas iniciais de seu trabalho no Brasil, que se encontra bastante dispersa em coleções públicas e particulares. Acompanhar o pensamento da crítica sobre o artista ajuda-nos a fixar uma imagem da obra.

Mas voltando a essas interpretações, é preciso ressaltar que se trata de maneira inevitável de uma visão parcial no sentido de que de 1953 até o ano de sua morte, em 1962, o artista ainda iria intensificar uma parcela significativa de sua produção - notadamente as paisagens diluídas e transparentes de Minas Gerais, também conhecidas como "paisagens imaginárias” (conjunto considerado pela crítica de arte mais recente como sua contribuição original à arte moderna brasileira).

\footnotetext{
${ }^{27}$ Cf. GUIGNARD, 1953, p. 3.
} 
Até aquele momento, pode-se afirmar que são principalmente as paisagens de temática mais pitoresca, nas quais predomina a delicadeza do traço fino e minucioso e o rico colorido que agradam a crítica. Toma-se como exemplo a tela Noite de São João (1942), comprada pelo Museum of Modern Art (Moma), na qual uma sensibilidade pura capta “a herança de nossas tradições regionais”, como afirmou uma vez Navarra. Ou ainda o pequeno conjunto de retratos de sabor primitivista como Família do fuzileiro naval (s.d.) [Fig. 3] e Os noivos (1937).

Por fim, há as paisagens do Jardim Botânico [Fig. 4] e de Itatiaia [Fig. 5], nas quais se percebe um sentido propriamente pictórico e uma tentativa de apreender as grandes ilusões do espaço. A produção gráfica de Guignard também já era bastante apreciada, e sua fama como professor que privilegiava o desenho como a base da criação artística bastante difundida. Na década de 1940, o Suplemento Autores e Livros do jornal A Manhã publica o “Álbum de Guignard” com desenhos inéditos das cidades mineiras e do Rio de Janeiro [Fig. 6 e Fig. 7]. 


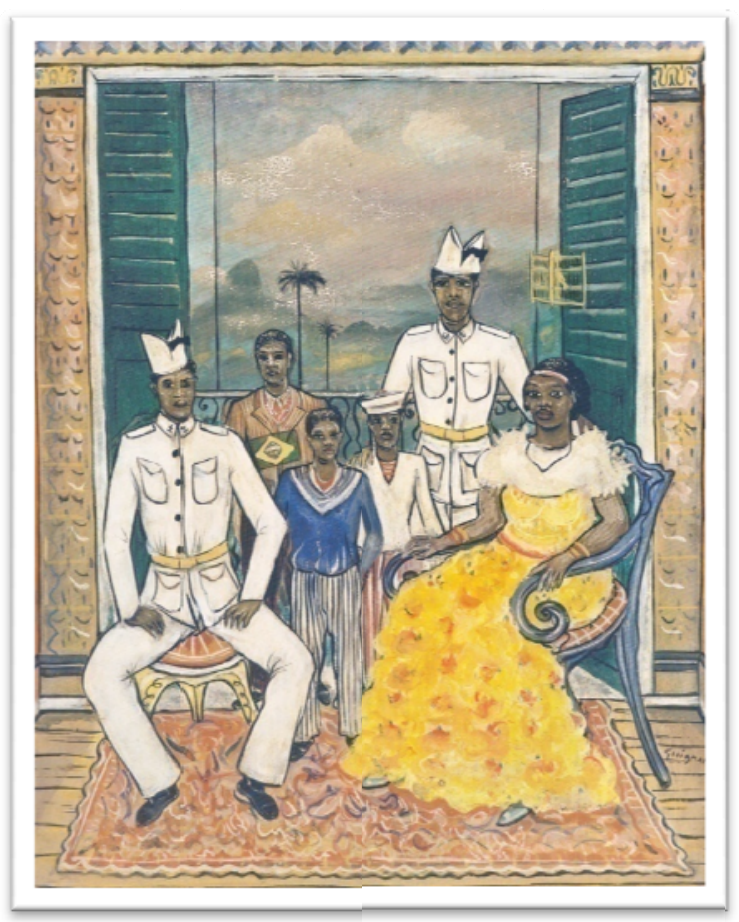

FIG.3 - FAMÍLIA DO FUZILEIRO NAVAL, S.D.

(ÓLEO SOBRE MADEIRA, 58 X 48 CM).

FIG.4 - JARDIM BOTÂNICO, C. 1937 (ÓLEO SOBRE MADEIRA, 76 X 76 CM).

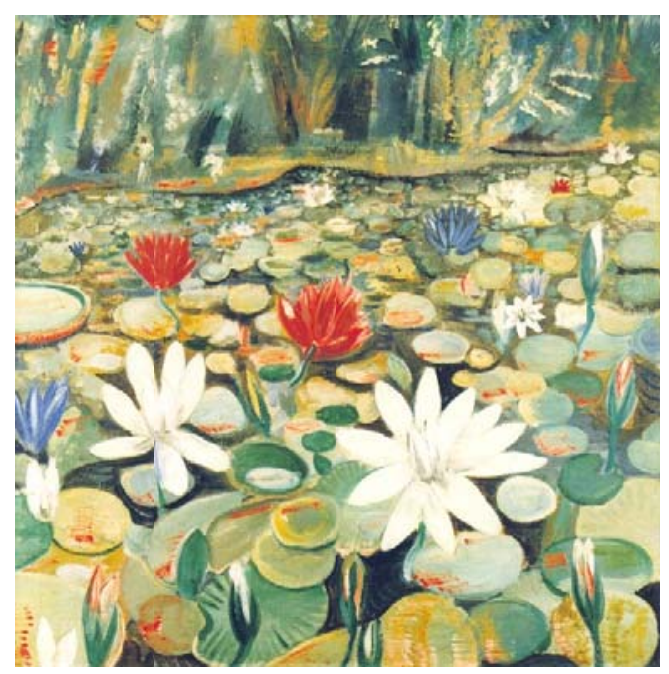




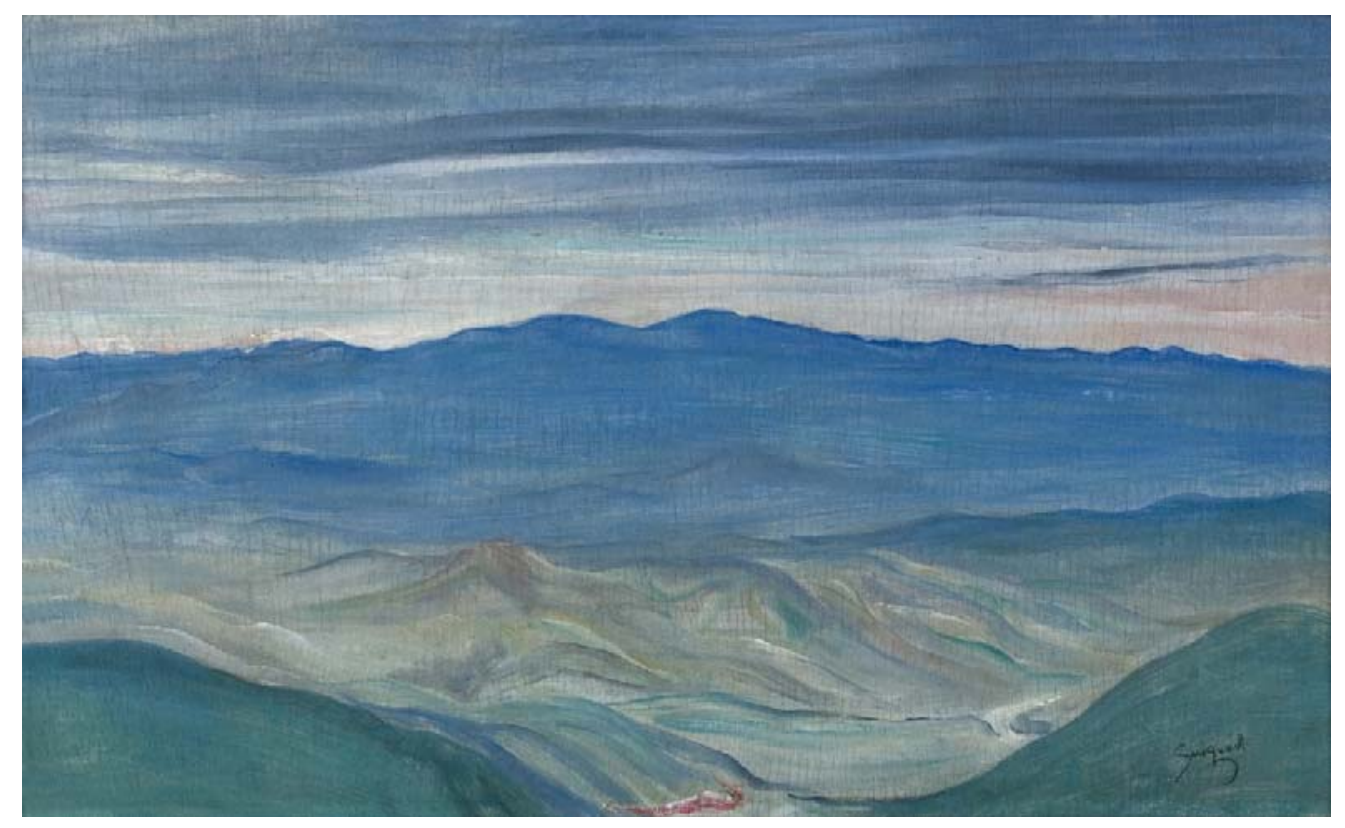

FIG. 5 - ITATIAIA, 1941 (ÓLEO SOBRE TELA, 32 X 50 CM)

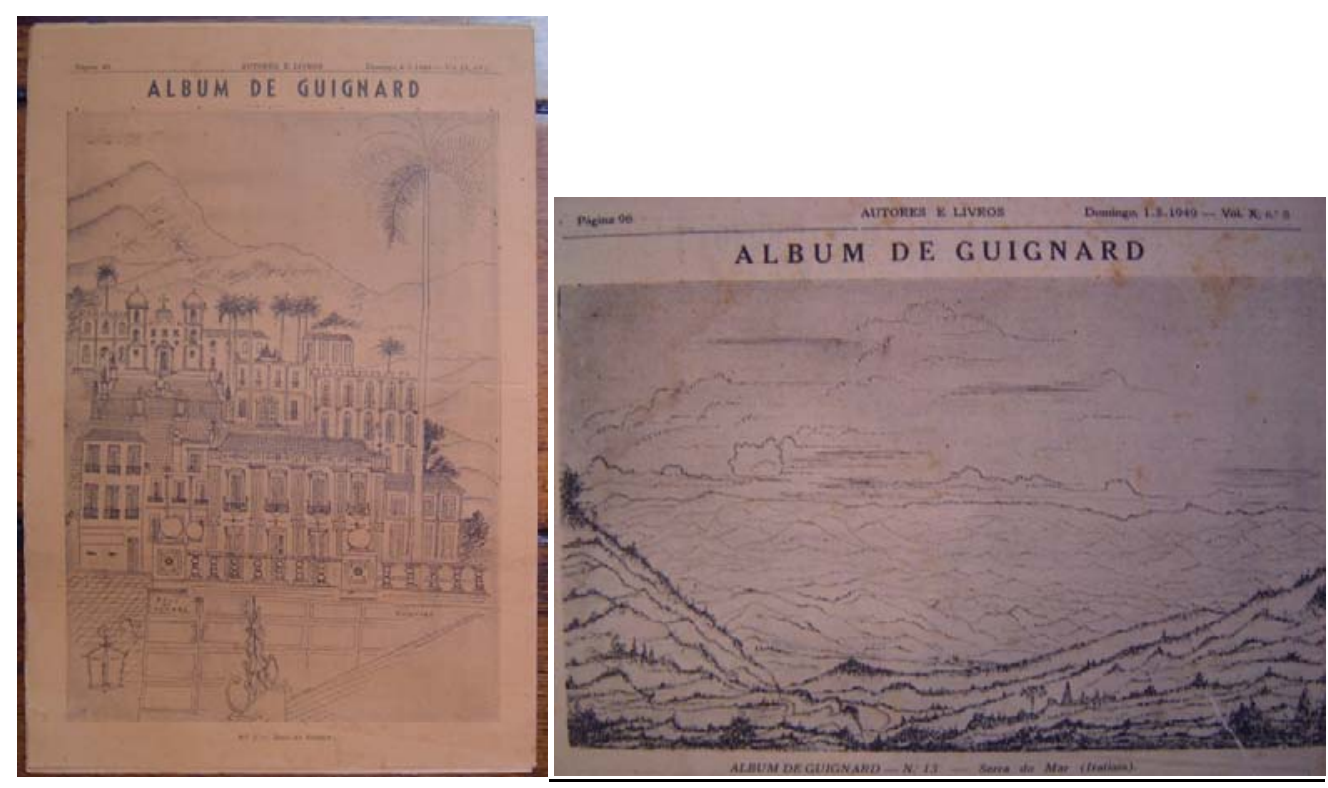

FIG. 6 - No 2 BECO DA SOMBRA, ÁLBUM DE GUIGNARD, 1948 FIG. 7 - No 13 - SERRA DO MAR (ITATIAIA), ÁLBUM DE GUIGNARD, 1949. 
Neste período inaugural de estabelecimento de uma história para a arte moderna brasileira, originalidade e autonomia em relação aos movimentos e modelos internacionais são duas características altamente valorizadas. E esses dois pontos parecem depender necessariamente do assunto, que permite tanto a superação dos modelos e técnicas “importados” quanto confere uma qualidade específica à arte brasileira ${ }^{28}$. Além de contribuir para redescoberta e fixação visual de uma identidade nacional autêntica, fiel à heterogeneidade de nossa formação cultural, que teria sido sufocada, segundo Mário de Andrade, pelo “francesismo colonizado e conservador” da intelectualidade do século 19.

Sabe-se que neste contexto, parte considerável do que depois seria institucionalizada como “a arte moderna brasileira” passa a assumir, a partir dos anos 1930, um direcionamento social mais engajado, preocupando-se em retratar a realidade social do país e retraindo-se em termos formais. Durante o “Estado Novo” do presidente Getúlio Vargas, momento em que a arte moderna parece alcançar uma maior dimensão pública, no campo das artes plásticas é o nacionalismo de cunho social de Portinari que encarna seu modelo aceitável, em uma forma clássico-realista com deformações expressivas e salientes dentro de um decoro que fixa o assunto nacional e do homem brasileiro na figura do trabalhador.

\footnotetext{
${ }^{28}$ Ruben Navarra expressa do seguinte modo essa posição: “A 'atmosfera brasileira’ está presente em nossos pintores, e isto é o primeiro passo, a primeira condição psicológica, para se chegar a uma arte nacional caracterizada e original. Sem dúvida não se trata de admitir que o 'assunto' seja bastante para definir uma arte como tal: o problema está no assunto, mas na maneira de tratá-lo também. De qualquer forma, o assunto, a temática é um valor de que não se pode prescindir (...) Considerando cada caso isoladamente, a 'qualidade' da pintura há de ser independente do seu assunto, mas olhando o conjunto do movimento artístico numa perspectiva histórica da cultura, é claro que não se pode falar de 'pintura brasileira' se essa pintura não tem raízes na terra (...)” (op. cit., p. 91).
} 
O que gostaríamos de enfatizar, mesmo sem nos estender sobre o assunto, é o fato do movimento modernista no Brasil, e sua posterior reconstrução histórica, parecer indissociável de uma orientação nacionalista. Num primeiro instante, o nacionalismo modernista assume a figura do primitivismo antropofágico de Oswald de Andrade em 1928. Para o escritor, não bastava a atualização do meio, era necessário “deglutir” o que vinha de fora e recriar a partir de uma experiência local. Já em 1920, Mário de Andrade via com desconfiança os elogios que Tarsila do Amaral fazia ao cubismo diretamente de Paris. Para ele, a arte moderna, tal como vinha sendo desenvolvida no centro, corria o risco de tornarse “excessivamente estetizante” e, em tom bem-humorado, convidava a amiga pintora a voltar para o Brasil, onde iria fundar um novo movimento, o “Matavirgismo”.

Naturalmente, há diversas versões de Nacionalismo. Entre a posição desses primeiros modernistas, que buscavam fundar o "homem novo” a partir da rejeição dos valores clássicos da tradição européia e da revalorização da arte “primitiva” brasileira de raízes africanas e indígenas (e que o crítico de arte Mário Pedrosa chamou, de modo simpático, de “nacionalismo ingênuo primitivo", "primordial, irredutível e antierudito”29) e as formas superficiais e estreitas de Nacionalismo patriótico que vão responder a desejos conservadores e reacionários, sobretudo a partir de meados dos anos 1930, há uma série de gradações.

Em suma, para o bem ou para o mal, a questão do nacional parece ter dominado a discussão teórica sobre o modernismo brasileiro na primeira metade do século 20. E isso se reflete nas primeiras interpretações críticas e históricas da produção de Guignard. No seu

\footnotetext{
${ }^{29}$ Mário PEDROSA, op. cit., pp.144-145.
} 
caso, o nacionalismo se manifestaria no apego sentimental e identificação a elementos mais prosaicos e singelos da vida brasileira, em contraposição ao heroísmo de um Portinari, por exemplo. O intelectual e amigo do artista, Rodrigo Melo Franco de Andrade, afirmava em 1967, que o que "impressionava Guignard não eram as ocorrências econômicas, sociais e políticas em desenvolvimento no país, fenômenos, para ele como que inexistentes. O que contemplava e aprendia eram os aspectos empolgantes ou comovedores da terra em que tinha nascido, os traços expressivos de sua população, o pitoresco das cidades grandes e pequenas, as peculiaridades da vegetação e dos acidentes naturais, o colorido das flores”30. Por isso, seu papel dentro do projeto da arte moderna brasileira teria sido o de valorização de uma tradição mais autêntica relacionada, sobretudo, a nosso lado rural, interiorano, em contato direto com a natureza, e longe dos centros urbanos.

Contudo, sabemos que Guignard não era um artista de extração popular. Ao contrário, por sua origem e educação talvez encarnasse a expressão mais genuína do brasileiro culto de formação européia. Além disso, estava longe da sensibilidade “proletária” e do autodidatismo do grupo de artistas paulistas na mesma época, e que era apontado como a mais nova tendência da arte dos anos 1940 por Mário de Andrade. Por isso, a maneira que parte da crítica encontrou de fundamentar seu lirismo nacionalista foi atrelando-o à sua suposta personalidade pura, ingênua, comparável à inocência das crianças. Pois apenas assim ele poderia se despojar de sua técnica refinada e culta para

\footnotetext{
${ }^{30}$ Rodrigo Mello de Franco ANDRADE, Guignard, p. 10.
} 
encantar-se com a "alma popular” do Brasil. Era como se fosse visto como um naïf sem sê$10^{31}$

O que prevalece então na primeira recepção crítica da obra é a figura de Guignard como o pintor-poeta inspirado, para o qual arte e vida se misturam tão profundamente, que no fim o homem parece viver a margem do mundo real. Desta forma, o que se enfatiza é seu aspecto temático e a capacidade que o artista tem de se inspirar pela paisagem natural e humana do país, revelando sua "alma”, que naturalmente, por ser a alma do povo simples e espelho do próprio artista, é repleta de pureza e bondade.

Seguindo essa leitura, como notou o crítico de arte Ronaldo Brito, se fixa o conteúdo da obra (seus assuntos) para privilegiar “uma leitura literária e sublimante que esconde o processo de formalização de Guignard sob os clichês naturalistas de alegre, ingênuo etc”. E essa abordagem, com exceções como vimos, coloca de lado as questões de linguagem. Mais: suas dificuldades técnicas seriam facilmente superadas por essa total empatia do sujeito pelo mundo dos fenômenos, quer dizer, o sujeito lírico seria capaz de transpor toda e qualquer dificuldade formal mediante um permanente "estado de graça”. O que resultaria em uma obra cujo caráter expressivo seria marcado pela pura espontaneidade.

É provável que Guignard se sentisse pressionado por demandas “sociais” quando volta ao Brasil em 1929. Alguns dos poucos desenhos que conseguimos localizar feitos

${ }^{31}$ Guignard participa da representação brasileira da XXVI Bienal de Veneza em 1952 com as telas "Festa em Família” (s.d), “Paisagem no Parque” (1947) e “Antes da última corrida” (1951), as duas primeiras pertencentes hoje ao acervo do MAC-USP. A seleção, como aponta texto de Sergio Milliet, procurava "respeitar as diversas tendências da atual pintura brasileira", entre elas, "a pintura ingênua". Por isso, participaram também artistas como Antônio José da Silva e Heitor dos Prazeres. Pela seleção de obras, é provável que Guignard fosse compreendido como artista ligado a essa tendência. (XXVI Biennale di Venezia, p. 190). 
neste ano têm como motivo os morros cariocas ${ }^{32}$. O próprio Guignard declara que ao chegar teria sofrido dois choques: o primeiro com o ambiente artístico acanhado e o segundo, mais profundo, com a própria natureza do país, suas cores e paisagem.

Mas hoje analisando a produção em seu conjunto, a ingenuidade da obra de Guignard parece "ingênua demais para ser exata"33. Se por um lado a associação do que seria essa cultura "arcaica” ou "popular” a noções como inocência, felicidade, simplicidade, entre outras, traz conotações ideológicas explícitas; por outro, é possível perceber em suas obras uma certa unidade dada pela reiteração de determinados elementos e esquemas compositivos que indicam a permanência de alguns problemas plásticos e a busca do artista em lidar com eles, para além de um mero interesse temático.

Se compararmos, por exemplo, uma de suas primeiras telas realizadas no Brasil, o Retrato de Felicitas Barreto (1931) [Fig.8], exposta pela primeira vez no "Salão de 1931" ou "Salão Revolucionário" com o título Paletó de Veludo, a uma das pinturas-símbolo de seu “lirismo nacionalista”, a já citada paisagem Noite de São João (1942) [Fig.9], percebese, a despeito da diferença de assunto, semelhanças em suas soluções compositivas.

${ }^{32}$ Segundo a pesquisadora Lélia Coelho FROTA, alguns desses trabalhos foram expostos na Mostra de Arte Social organizada por Aníbal Machado, Álvaro Moreyra e Santa Rosa em 1935. Em observação sobre os desenhos, Machado comenta com um leve tom de censura, depois de mencionar as qualidades de sua fatura e execução, que "assim dotado, é preciso que ele compreenda que, através de sua arte, muita coisa há que exprimir além dos retratos e das flores estupendas que tem pintado" (FROTA, p. 36-37). Comentário que de certa maneira revela o tom geral do meio artístico na época.

${ }^{33}$ Ronaldo BRITO, op. cit., p. 12. 


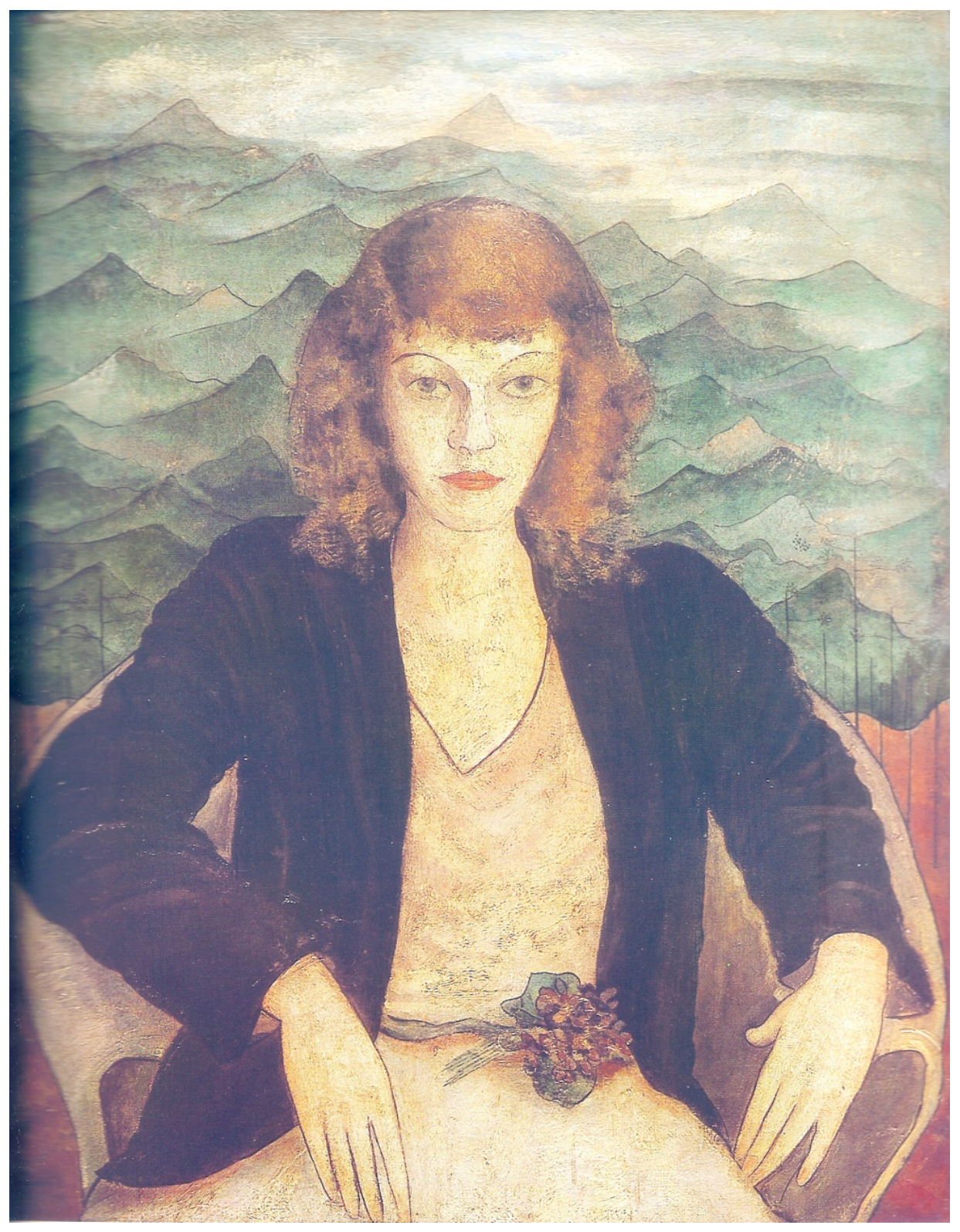

FIG.8 - RETRATO DE FELICITAS BARRETO, 1931 (ÓLEO SOBRE TELA, 89 X 70 CM). 
No caso do retrato, a figura é representada sentada em uma poltrona (o que é raro no caso de Guignard) em primeiro plano com cerca de 2/3 de seu corpo ocupando o espaço da tela. Ao fundo, vê-se em um espaço aberto que ocupa exatamente a metade superior da pintura, uma paisagem montanhosa na qual céu e terra se confundem em uma tonalidade azul-esverdeada. Vista ao longe, a paisagem impõe uma perspectiva aérea que contrasta com a frontalidade estática da figura.

Tanto essa posição frontal quanto o movimento ascensional sugerido pelas montanhas - que são tratadas como ondas ou como sobreposições de manchas horizontais denotam um tipo de construção espacial presente em muitos dos trabalhos do artista, mediante o qual já se entrevê sua maneira singular e recorrente de produzir tensão entre a superfície pictórica e a profundidade de sua representação. Pois há, em seus melhores trabalhos, uma espacialidade ambígua, na qual a projeção em direção a um fundo infinito é tensionada pela correspondente verticalização do espaço que tende a projetar a imagem para superfície do quadro.

Por outro lado, essa espécie de "descontinuidade" entre figura e fundo revela a adoção de um duplo ponto de vista: tem-se simultaneamente a sensação de proximidade e distância. Essa dissonância está na origem de um certo estranhamento, sugerindo quase um procedimento de colagem, como se o artista tivesse se apropriado de uma imagem já existente sobre a qual justapõe um determinado motivo ${ }^{34}$. E na verdade, muitos dos céus coloridos e transparentes de Guignard irão servir de pano de fundo para os mais diversos

${ }^{34}$ Ruben Navarra, por exemplo, via essa descontinuidade como algo negativo nos retratos de Guignard: “Com isso é que venho embirrando há algum tempo. É uma coisa assim entre o céu e montanha de formas confusas e tons decorativos, formando um pano de fundo que não chega a fazer unidade plástica ou espiritual com o retrato. Fica a figura solta sobrando no fundo" (apud. Piedade GRINBERG, op. cit., p. 130). 
assuntos, como vasos de flores, cenas oníricas, cidades coloniais etc; até o momento em que eles se autonomizam e se constituem como o assunto mesmo do quadro.

Outra característica que chama a atenção neste retrato de Felicitas Barreto é a consciência aguda da linha que emana da composição, dotando as formas do quadro de uma qualidade sintética que revela toda a expressividade do estilo linear de Guignard. A presença delicada do desenho dá ao conjunto uma sensação geral de leveza, como se a corporeidade dos objetos tivesse a densidade de uma folha de papel.

Sem se prender a uma descrição minuciosa, ele exalta algumas particularidades significativas: as mãos delicadas de dedos finos e compridos; as curvas da poltrona; o decote discreto do vestido; a flor que serve como cinto; as linhas delicadas que unem sobrancelhas, olhos e nariz; o contorno quase imperceptível do rosto e da boca; as poucas árvores retas e estáticas; os contornos descontínuos das montanhas. Em sua união, esses traços atingem uma harmonia delicada entre um suave ritmo ascendente e descendente, um equilíbrio entre movimentos horizontais, verticais e as curvas da poltrona que acompanham a posição dos braços e das mãos. Há uma serenidade concentrada - tão bem representada pela expressão da face da modelo, ao mesmo tempo séria e doce - que parece reverberar pela superfície do quadro.

A estabilidade não se constitui em rigidez. Tudo aqui parece sugerir dinamismo suave, quase invisível. As montanhas que se fundem às nuvens em tonalidades azulesbranquiçadas, parecem sujeitas a ações simultâneas de aparecimento e de desaparecimento, na medida em que são delineadas de forma descontínua. A sensação é de 
que estamos diante de um momento de passagem, provavelmente o entardecer, em que a aparência do mundo visível está em vias de se modificar.

A respeito do tema representado, podemos apontar a ambigüidade implícita nessa figura loira de olhos esverdeados, andrógina, que também parece viver um momento de transformação. Sua face ainda pouco feminina de adolescente é investida de pureza, espelhada pela falta de adereços a destacar seu corpo de mulher. O leve vestido rosa, que sugere transparência, está de maneira decorosa coberto pelo casaco de veludo marrom. Sem jóias, colares, chapéu ou pulseiras, a flor lilás, símbolo de pureza, atada por uma fita verde à cintura, ganha um significado especial. Com certeza, essa menina pertence à elite brasileira da época, e por isso pode-se muito bem imaginar que ela está prestes a encenar o papel principal em um baile de debutantes, que é também um ritual de passagem. A boca vermelha e o olhar decidido que nos encara sem timidez revelam, entretanto, uma força e uma sensualidade em vias de desabrochar.

Com relação ao colorido, tons quentes como o marrom escuro da roupa, o avermelhado no que parece ser uma parede ao fundo, o tom loiro dos cabelos, o rosa encarnado da pele, do vestido e da poltrona, se harmonizam com os verdes e azuis mais frios que dominam o fundo do quadro, e que se fazem presentes em menores quantidades nas vestes e nos olhos da figura. Apesar da rugosidade da superfície pictórica, tem-se uma impressão geral de transparência que se dá pela luminosidade etérea a banhar o quadro e que está concentrada na imagem quase incorpórea dessa figura de mulher.

É provável que o artista tenha realizado essa pintura por encomenda, pois como sabemos, Guignard desde os primeiros anos de sua carreira artística no Brasil, pinta retratos 
muitas vezes como forma de retribuição por hospedagem e alimentação. Ao optar em trabalhar um tema solene de maneira tão delicada e pouco realista, ele já dá mostras da potência de uma visão lírica apoiada sobre bases formais muito claras. Pois naturalmente nada aqui se dá por acaso. Na concisão de seu estilo linear, a delicadeza e seriedade da menina lembram uma virgem incorpórea da pintura renascentista. O cenário das montanhas ao fundo simbolizam o desconhecido e o mistério da natureza, e por associação, da natureza feminina, e são também muito comuns na retratística da Renascença. As cores, trabalhadas sem alarde ou contrastes fortes, compõem uma harmonia tonal que evoca ao mesmo tempo serenidade e uma certa melancolia.

Há diversas semelhanças entre este retrato e o importante quadro "Noite de São João” e que é conhecido como um dos mais significativos exemplares do lirismo nacionalista de Guignard. Vale dizer que, salvo engano, a primeira pintura de Guignard que retrata uma noite de São João data de 1939 e possui o título (atribuído) "Paisagem Imaginante”. De certa forma, essa troca de títulos (são paisagens reais ou imaginárias?) já indica o viés pouco realista com o qual o artista iria tratar seus quadros ditos “nacionalistas”. 


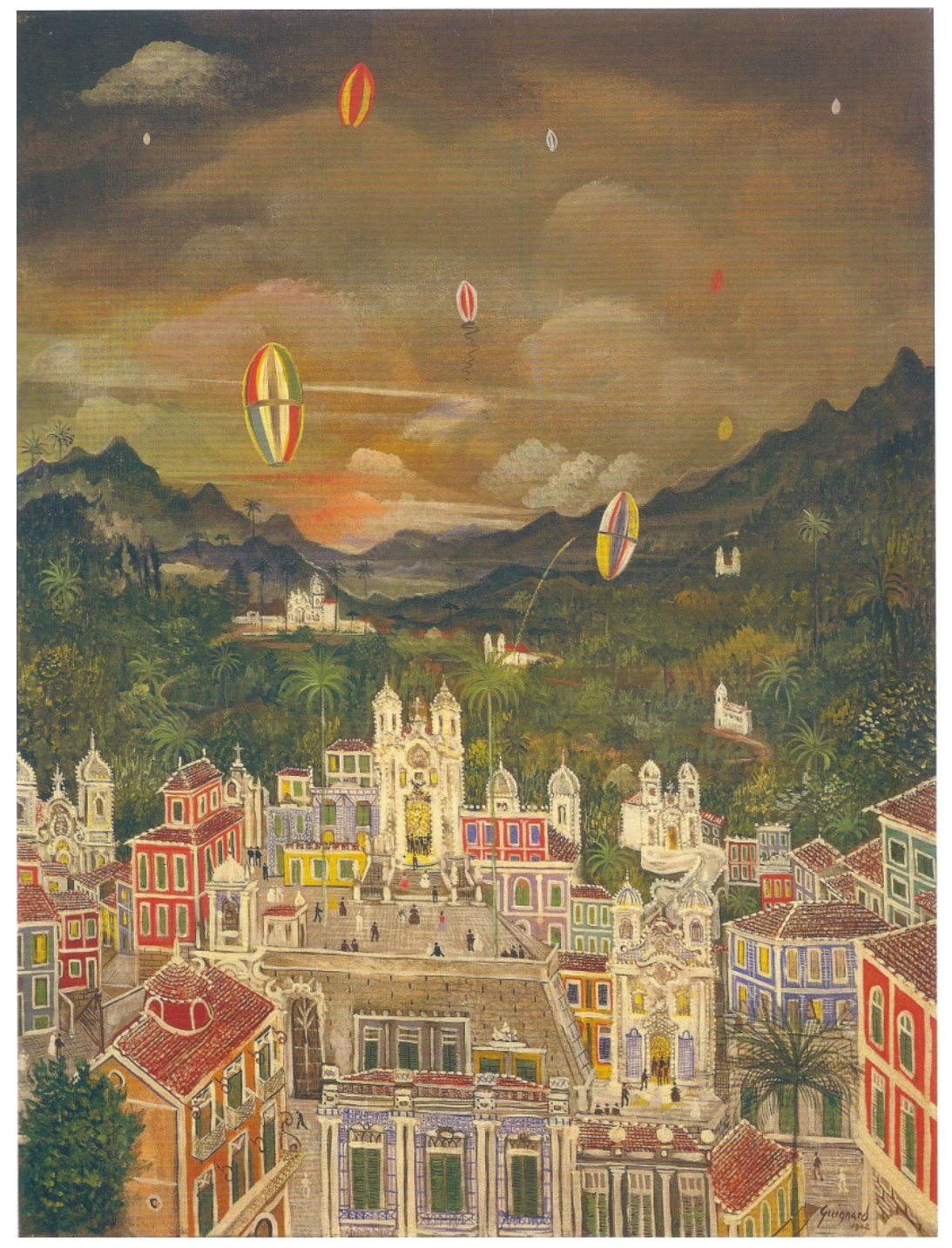

FIG.9 - NOITE DE SÃO JOÃO, 1942 (ÓLEO SOBRE MADEIRA, 80 X 60 CM). 


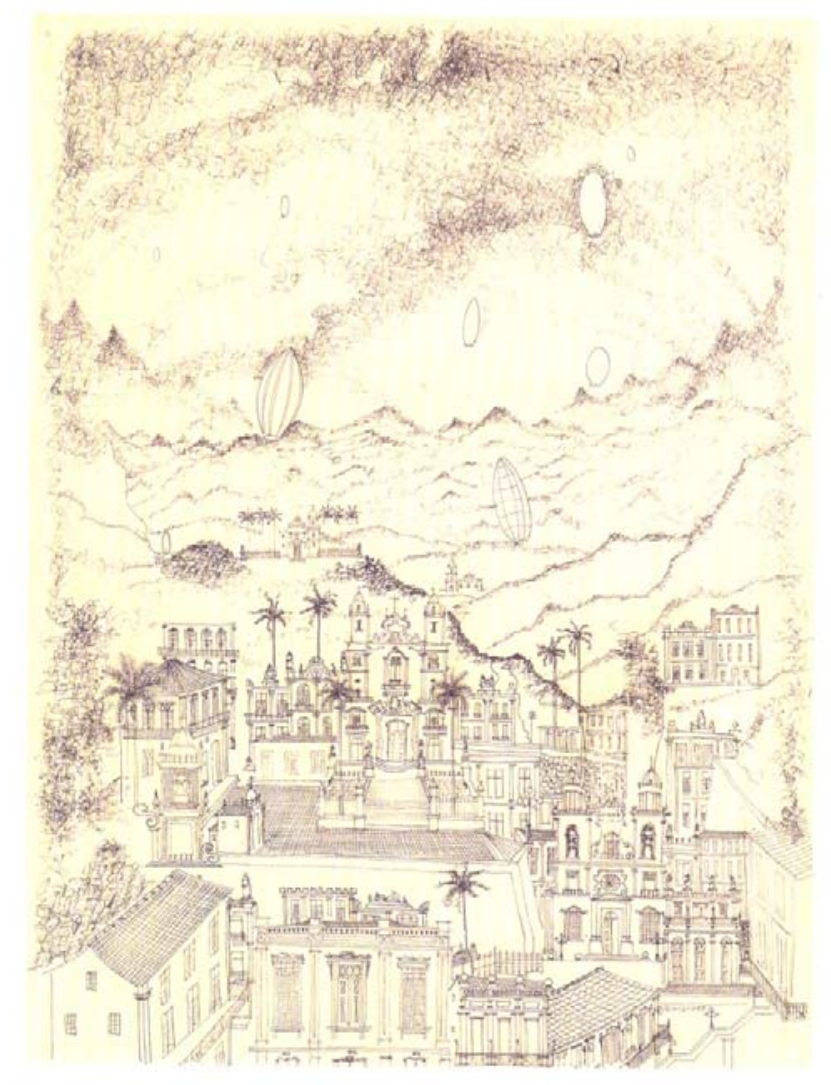

FIG. 10 - NOITE DE SÃO JOÃO, 1942 (CANETA SOBRE PAPEL, 36 X 27 CM).

No caso da pintura de 1942, vemos ao fundo a mesma intenção de apresentar um espaço amplo mediante uma paisagem montanhosa e nuvens que ocupam um pouco mais da metade do quadro. O cenário brumoso e quase monocromático do retrato ganha novas cores, ainda mais diversificadas na cidade colonial em primeiro plano ${ }^{35}$, que no fim acaba ocupando o mesmo lugar centralizado da figura feminina na tela anterior. Aliás, diga-se de passagem, é significativo que o artista irá adotar para realização de muitas de suas

${ }^{35}$ Segundo estudo de Cláudio Valério Teixeira (“Como Balões de São João - técnicas e processos na pintura de Alberto da Veiga Guignard”, in: Alberto da Veiga Guignard - 1896-1962, pp. 44-51) basicamente são onze os pigmentos encontrados em suas pinturas: branco de chumbo, ocre claro, lilás ou um tipo de violeta, terra de Siena, azul cobalto, azul cerúleo, vermelhão francês, amarelo de cádmio, verde émeraud, preto (talvez negro de marfim) e carmim. 
paisagens o suporte retangular em posição vertical ereta, seja em tela, em madeira ou papel, e que é tradicionalmente comum à pintura de retratos, mas menos usual na pintura de paisagem. A isso voltaremos posteriormente.

Nota-se que mesmo na pintura o desenho determina a construção em primeiro plano. A delicadeza e a minúcia com que o traço fino reconstrói a arquitetura dessa cidade imaginária dão a sensação de se tratar de um cenário de papel, de materialidade frágil e quase sem volume. O que se confirma pela maneira como ele ordenar os elementos desta arquitetura (edifícios, muros, igrejas, praças, escadas, átrios) como peças encaixadas sem que seja possível vislumbrar a real organização deste espaço do ponto de vista de sua tridimensionalidade. A linha, em várias cores, ganha uma função decorativa particular. A sensação é de que Guignard teria, depois de terminada a pintura, se dedicado a "enfeitar” a superfície, desenhando com um pincel muito fino cada detalhe arquitetônico, as pessoas e os balões coloridos no céu ${ }^{36}$. A luz surge pulverizada em diversos pontinhos e tracinhos brancos, o que dá a sensação de uma tênue vibração luminosa. Há assim uma presença do desenho que certamente tem um papel descritivo, mas que também possui a capacidade de se afirmar como puro elemento plástico-decorativo.

${ }^{36}$ Há depoimentos de seus alunos, como por exemplo Iberê Camargo, Maria Helena Andrés e Alcides da Rocha Miranda, que indicam que Guignard primeiro pintava o fundo com um pincel redondo e depois desenhava por cima com um pincel bem fino, "pincel de filete", sobretudo nas paisagens. O que é confirmado pelas palavras do ex-aluno e pintor Mário Silésio: "Ele não gostava que se desenhasse nas telas antes de pintar - o desenho não era usado como esboço, nem pelos alunos nem por ele. Dizia sempre que o céu vinha primeiro, porque fica mais no fundo. Mas ele pintava o céu e sujava a tela até embaixo porque o branco da tela o irritava. Depois do céu vinha a montanha, de várias cores (...) descia com aquela tinta até embaixo. Dizia que isto enriquecia a matéria do quadro depois de terminado. (...) Depois colocava as casas, as pontes, as árvores, o que estava em primeiro plano.” (apud. A Modernidade em Guignard, 145). 
Pois não estamos diante de uma descrição topográfica. Como podemos constatar pelo desenho considerado o estudo para esse quadro, Guignard cria uma paisagem que responde a uma organização própria (seguindo novamente a direção do espaço determinada pela folha de papel), e que exatamente por seu caráter minucioso nos leva a crer que se trata de uma visão onírica [Fig. 8], no sentido de que não parece corresponder a uma imagem de uma cidade real ${ }^{37}$ e apesar da construção montanhosa ao fundo remeter diretamente a seus desenhos de vistas de Itatiaia [Fig. 5]. Nenhuma cidade real contém tantos elementos decorativos entrelaçados. A delicadeza e fineza da linha e sua trama nos lembra um rendilhado artesanal.

Neste quadro o fundo é definitivamente trabalhado em termos de manchas de cor, o que cria um contraste curioso entre os planos. De certa forma, parece que a arquitetura não se integra totalmente à paisagem e vice-e-versa. Guignard sugere a profundidade pela eliminação paulatina do grafismo, que parece desmanchar lentamente com a passagem do primeiro para o segundo plano, representado pela vegetação que se inicia logo atrás da igreja central, e que é arrematado pelo céu de horizonte largo trabalhado com pincel redondo em vários tons de cinza com notas coloridas, criando um volume levemente modulado.

Mas a verticalidade do espaço acaba projetando novamente o que está atrás para frente, bem como as palmeiras e balões que pontuam aqui e ali o céu e as montanhas. De

${ }^{37}$ Tanto a pintura quanto o desenho pertencem desde 1942 à coleção do Museu de Arte Moderna de Nova York (MoMa) e ambos foram catalogados com o título Ouro Preto: Noite de São João. Contudo, quando a tela foi apresentada pela primeira vez no $48^{\circ}$ Salão Nacional de Belas Artes no mesmo ano trazia o nome mais genérico de Festa de São João. Nesta edição do Salão, o artista recebe a medalha de ouro pela Divisão Moderna com a paisagem Serra do Mar - Itatiaia. Fazem parte da comissão de seleção Aníbal Machado, Candido Portinari e Oscar Niemeyer. 
certa forma, essa solução impede por um lado que a cidade iluminada seja envolta pela densidade úmida deste céu de entardecer, evitando assim seu possível caráter ameaçador; por outro, na medida em que esse desenho minucioso não se afirma de maneira totalmente unitária pela superfície da tela, evita o excesso que facilmente redundaria em uma visão demasiadamente pitoresca ou anedótica.

No que diz respeito ao assunto tratado, é claro que não podemos ignorar sua implicação nacional. Ninguém pintou tantas vezes como Guignard essas festas juninas que são, como sabemos, festas católicas populares de grande importância cultural no Nordeste e no chamado Brasil caipira, e que acabaram se tornado uma "marca” do artista. E no caso analisado, está ainda associada à imagem de uma cidade colonial. Uma vez Guignard justificou a escolha deste “tema” como algo relacionado a sua memória afetiva: seu pai, que morrera quando este ainda era criança, o acordava para ver os festejos juninos que coincidiam com a data de seu aniversário. Mas não se pode negar, para além das justificativas de cunho biográfico - que com certeza o artista ajudava a propagar - as implicações ideológicas dessa escolha, posto que estão de acordo com a valorização da cultura popular como cultura nacional empreendida pelos primeiros modernistas e que de certa maneira foi institucionalizada durante o governo de Getúlio Vargas (1930-1945).

O que gostaríamos de ressaltar, todavia, é que para além de um simples interesse temático, essas paisagens comportam uma pesquisa do espaço, da relação entre cor e desenho, figura e fundo, que como vimos se manifesta em outras telas do mesmo período, e que no fim irá se tornar a contribuição mais original de Guignard para a arte brasileira. O que pode ser visto como um patriotismo de base simples e ingênua nessas telas não 
significa que sua linguagem seja fruto da mais pura espontaneidade, de um olhar que simplesmente se desfaz de suas referências para "sentir" de modo mais direto a "alma" deste Brasil.

Há aqui, ao contrário, um exercício evidente de construção que não pode ser ignorado. Como apontado anteriormente, algumas características fundamentais de seus trabalhos, por exemplo, o grafismo delicado e fluido que marca o ritmo da composição; a transparência no uso das cores, trabalhadas de maneira modulada em camadas e não pela justaposição de campos de cor pura; uma luz que se apresenta como matéria diáfana; os horizontes definidos de maneira tênue e que sugerem um ponto de fusão entre a terra e o céu, a matéria e o ar; a conjunção entre proximidade e distância que sugere um olhar contemplativo sobre as coisas; a verticalidade espacial, todos estes são elementos que dão a seus trabalhos uma fatura e aparência bastante singulares e por isso são determinantes para caracterização de seu lirismo, atravessando momentos distintos da obra, não necessariamente relacionados a uma temática nacional.

Se há mesmo dois pólos na pintura de Guignard, a saber, por um lado a atração pela visão fantasiosa e subjetiva, de origem romântico-simbolista que tende a dominar suas obras mais literárias, e por outro, uma posição de observação contemplativa do mundo exterior, do homem e da natureza, como afirmava Mário Pedrosa, esses são impulsos de intensidade variável no decorrer do tempo, que se mesclam e equilibram, até configurarem uma forma na qual se expressa uma experiência lírica a partir de um movimento pendular a 
uma só vez para dentro e para fora - numa atitude de "evasão do e para o mundo"38, que para além do pitoresco regional, procura fundir seus traços localistas à universalidade da arte.

${ }^{38}$ Emprestamos esta formulação extremamente feliz ao crítico literário Davi ARRIGUCCI Jr. que com ela assinala o movimento do eu lírico na poesia de Manuel Bandeira. Ele permitiria "uma resoluta objetivação da experiência mais funda na forma do poema, desentranhando ao mesmo tempo da alma e da circunstância, fundindo memória e momento ...” (p. 22). As afinidades poéticas entre os dois artistas, o poeta e o pintor, já foram apontadas por alguns críticos. Cf. o capítulo “Alumbramento: Guignard e Bandeira” de José Augusto RIBEIRO (Guignard e o ambiente artístico no Brasil nas décadas de 1930 e 1940, p. 37). 


\section{CAPÍtUlo 2}

\section{A QUESTÃO DA MODERNIDADE E DA RUPTURA}

Apesar da declaração de que teria sofrido um duplo choque quando aportou no Rio de Janeiro em 1929, com o meio artístico e com a paisagem, e ao qual voltaremos mais adiante, é certo que desde o início a obra de Guignard não parecia inspirada pelo gesto de ruptura ou tabula rasa que constituiu boa parte do ímpeto das vanguardas históricas do início do século 20. A mescla de linguagens figurativas modernas que pode ser apontada em suas pinturas e sua fidelidade à divisão pós-renascentista da pintura de gênero o aproxima da produção dos artistas que vivem e produzem no âmbito da "Escola de Paris”39 após a Primeira Guerra Mundial. Contudo, Guignard segue um percurso singular, no qual

${ }^{39}$ Sigo aqui a definição que G. C. ARGAN faz dessa escola: “o de um grande bazar, onde são admitidas e misturam-se todas as correntes e tendências, sob a única condição de serem 'modernas'. O fato historicamente mais significativo é que, nesse contexto, a tradição do Impressionismo deixa de ser uma tradição francesa, e a do Expressionismo uma tradição alemã” ( $A$ Arte Moderna, p. 341). "O mercado artístico parisiense foi o maior responsável da assim chamada Escola de Paris, termo com que se indicou a confluência em Paris, na primeira metade do século, de artistas originários de todos os países do mundo e dispostos a suportar anos de miséria na esperança, na maioria dos casos frustrada, de uma 'consagração' ou de um 'lançamento' por algum grande marchand" ("A arte do século XX", in A Arte Moderna na Europa de Hogarth a Picasso, p. 444). Os três "guias" artísticos desta "escola" foram Picasso, Matisse e Braque, na época também os pilares do mercado internacional. A total liberdade artística e o tema comum do ideal romântico "da arte como poesia e da poesia como vida" marcariam a produção desses artistas aspirantes, que tentavam combinar o vocabulário moderno "universal” com as tradições de seus países de origem, colocando-as na circulação da sociedade cosmopolita. Entre seus integrantes, por exemplo, encontra-se o russo Marc Chagall, o italiano Amedeo Modigliani, o romeno Constantin Brancusi, os brasileiros Vicente do Rego Monteiro e Cícero Dias, entre outros. 
se dá ao mesmo tempo uma aproximação e um afastamento do vocabulário moderno, em que seu olhar não vê apenas na França o único centro irradiador da modernidade, mas passa igualmente pelas tradições dos países do Norte e da Itália, antes de aportar no Brasil.

Há no seu caso uma assimilação seletiva tanto da arte dos “antigos mestres” como da arte moderna, como revelam seus trabalhos e é explicitado por raros depoimentos sobre suas preferências e concepção artísticas não por acaso proferidos durante os anos 1940. Em matéria e entrevista publicadas em 1944 no Suplemento Literário do jornal “A Manhã”, encontramos suas opiniões sobre diversos assuntos: a arte acadêmica, a importância do desenho como exercício de observação para criação em artes plásticas, sobre seus alunos e seu método pedagógico, sobre a importância da organização, no Brasil, de um museu dedicado à arte moderna etc. Mas o que chama mais atenção são as considerações que faz sobre pintura. Em um momento histórico no qual, segundo o próprio entrevistador, dentro deste campo “os gostos se contradizem”, Guignard afirma:

“A verdadeira pintura moderna? Não é mais do que, em nossa época, seguir os passos da penetração artística de um Leonardo da Vinci, de um Holbein, de um Goya, e tantos outros. Giotto, e logo depois Paolo Uccello, e na mesma época Piero della Francesca, tão expressivos na sua fase ao mesmo tempo simples e monumental - todos esses eram no seu tempo considerados 'modernistas'.Um sincero modernista de 1944 jamais terá a ousadia de produzir monstruosidades, à guisa de arte, ou será um falso modernista.”

Mais adiante, continua:

Já estamos longe de nos impressionar com as excentricidades do cubismo e de todos os 'ismos', porque já passaram, morreram e estão enterrados. A pintura surrealista (uma das invenções mais novas) que se deve ao espanhol Salvador Dali, não é mais nada do que um esforço de reintegração no caminho da pintura clássica - a pintura 
de um Antonio Pallaiolo ou no quadro de Sandro Botticelli O Nascimento de Venus, ou ainda em muitas obras de Pieter Brueghel e outros surrealistas de 1500...” [grifos nossos] $]^{40}$

Se por um lado, a declaração não deixa de ter um tom provocativo (tendo em vista provavelmente essa dinâmica cultural muito particular dos países periféricos sempre prontos a aderir ao último ismo vindo de ultramar), por outro não deixa de ser sincera na medida em que manifesta uma opinião verdadeira, e que apresenta reflexos na dinâmica constitutiva de seus trabalhos. Ou seja, no seu caso, não se trata de mera retórica. Quatro anos depois dessa matéria, no conhecido “Questionário Krebbs”, ele retomará sua posição ao responder à pergunta sobre qual corrente ou escola segue, com a seguinte formulação: “Arte moderna mais (sic) com base clássica" 41

De certa maneira, poder-se-ia dizer que esses depoimentos e entrevistas, no momento em que são proferidos, explicitam a vontade do artista para que sua própria obra fosse interpretada para além de seu caráter ingênuo ou pitoresco, o que é bastante significativo $^{42}$. Porém, o que se deduz destas afirmações é também o apreço de Guignard pelas questões técnicas. No momento em que começam a se estabelecer marcos e valores para história da arte moderna brasileira - e não é por acaso pelo artigo de jornal subentendese uma divisão entre verdadeiros e falsos modernistas - há uma reprovação diante da banalização da idéia de modernidade pela mão de pintores que confundiam o desprezo pelo

\footnotetext{
${ }^{40}$ Apud. Raul de SÃO VICTOR, “A pintura moderna no Brasil”, A Manhã, 01/10/1944; matéria parcialmente reproduzida in: Carlos ZÍLIO (org.), A modernidade em Guignard, p. 34.

${ }^{41}$ Trata-se de resposta à pergunta n'33 "Em arte segue alguma corrente ou escola? Qual?”. O manuscrito original com as respostas do artista encontra-se no arquivo do Museu Casa Guignard em Ouro Preto. A entrevista foi reproduzida na íntegra in: Lélia Coelho FROTA, Guignard, arte, vida, pp. 299-301.

${ }^{42} \mathrm{E}$ que de resto nos distanciam um pouco daquela imagem de Guignard com um homem totalmente ingênuo, infantil e desligado do mundo, dada a lucidez de suas declarações sobre arte.
} 
aprendizado técnico e pelo desenho a uma atitude antiacadêmica. Diga-se de passagem, é conhecida a importância que Guignard como professor ${ }^{43}$ atribuía ao estudo dos "clássicos” ou "antigos", como ele dizia, principalmente dos artistas renascentistas, aconselhando seus alunos a visitarem museus e pesquisarem reproduções em livros de arte, mesmo que, como afirma em depoimento um de seus colegas de “Grupo Guignard”, o arquiteto Alcides da Rocha Miranda, tal método não se constituísse em “eruditismo”»44.

Por outro lado, é certo que em sua aparência e fatura, seus trabalhos reafirmam uma noção de continuidade com a tradição. Por exemplo, não saberíamos quantificar dentro do conjunto da obra o número exato de quadros nos quais ele utiliza como suporte a madeira no lugar da tela, mas a impressão é que esses representam a maioria. A madeira, como suporte para pintura, remonta ao antigo Egito, e foi amplamente utilizada para quadros de pequenas dimensões durante toda a Idade Média e o Renascimento, sendo sua solidez e expansão limitada apropriadas a pouca elasticidade da pintura a têmpera. Ao que parece,

${ }^{43}$ Em seu programa de curso para o Instituto de Belas Artes da Prefeitura de Belo Horizonte, escrito em 1944, ele anotaria dentre suas diretrizes pedagógicas: “A matéria principal do curso será o desenho, base fundamental das artes plásticas”. E em suas anotações ao programa segue: "Mostrar o que é bom ou mau gosto, o que é belo e o que é feio. Demonstrar como os antigos pintavam. Enfim, facilitar ao aluno uma maior facilidade de observar, ver e sentir". Também em carta escrita ao jovem pintor Mário Maués, datada de 1952, ele afirmará: "Dizem por aí que muitos artistas modernos não sabem desenhar. É um grande engano, eles na sua maioria o sabem muitíssimo bem, como Picasso, Raoul Dufy, Van Gogh e até dois superrealistas, Max Ernst e Salvador Dalí. Também Leonardo da Vinci e o maior de todos Botticelli. Muitos artistas foram gênios natos, outros grandes talentos e alguns apenas talentos querendo aprender. Minha profissão como artista requereu muito exercício, muita boa vontade e principalmente uma grande tenacidade. Sem isso nada se faz", aconselhando-o por fim "a visitar a miúdo boas exposições de arte, estudar mais amiúdo originais ou boas reproduções dos antigos" (ambos os textos de época citados foram transcritos nos anexos do livro de Lélia Coelho FROTA, op. cit., pp. 299-302).

${ }^{44}$ Segundo depoimento de Alcides da Rocha Miranda "ele aconselhava aos alunos que fossem à Biblioteca Nacional para verem as impressões de gravuras e desenhos. Íamos, mas nas aulas não fazia exercícios nem comentava sobre isso. Guignard era contrário ao eruditismo. Só lhe interessava a empatia. Ele gostava do movimento moderno porque era contra o academicismo, não que ele gostasse especialmente de pintura dita moderna”. (in: A modernidade em Guignard, PUCRio, p.123). 
como suporte ela foi bem pouco utilizada pelos artistas modernos, sobretudo no século 20 . Entretanto, em um de seus manuscritos com “receitas" de procedimentos e técnicas artísticas elaborados para suas aulas, Guignard mostra um grande domínio na preparação deste suporte, indicando-o como uma escolha natural a seus alunos ${ }^{45}$.

Outro dado interessante é que Guignard praticava e indicava a técnica conhecida como "pintura mista ou resinosa", procedimento que é caracterizado pela adição de vernizes ou resinas à tinta a óleo. Segundo seu inventor, o pintor e conservador alemão Max Doerner, que era professor na Real Academia de Artes de Munique e publicou o estudo “Os materiais do artista” em 1921, essa mistura seria a chave do segredo dos velhos mestres e de seus efeitos de translucidez e luminosidade. Sua teoria, que posteriormente se provou equivocada, e seu correspondente manual de pintura se tornaram muito populares na época e foram amplamente utilizados, sendo provável que Guignard os conhecesse desde seus tempos de estudante.

Ao trazermos à tona tanto as opiniões do artista como dados de natureza técnica não queremos reduzir a questão da relação entre modernidade e tradição em Guignard a dados simplesmente “concretos”. No entanto, como tais escolhas dizem respeito a efeitos visuais, essas informações nos ajudam a entender a gênese compositiva de seus trabalhos. Sabe-se, por exemplo, que a luminosidade e efeito de transparência de suas telas dão-se pela sobreposição de camadas "magras" de tinta a óleo sobre uma base clara ou branca geralmente polida, que muitas vezes, principalmente naqueles de fatura mais diluída, tornase parte constituinte da imagem representada. E é dessa sobreposição de cores que ele retira

${ }^{45}$ Conferir reprodução do documento e análise de Cláudio Valério Teixeira no ensaio “Como balões de São João: técnicas e processos na pintura de Alberto da Veiga Guignard”, op.cit., p. 44-51. 
sua vibração cromática tonal, e não a partir de um equilíbrio de dissonâncias de cor pura como a maior parte dos pintores modernos pós-impressionistas.

Mas obviamente não há nessa visão qualquer defesa de manutenção de uma atitude acadêmica a prescrever a cópia de um modelo clássico ideal. Há aqui a utilização, feitas as contas, de um expediente que também é moderno. De resto, é preciso notar que também a compreensão da arte moderna como um processo de assimilação com autonomia da tradição (em suas manifestações ocidentais ou não-ocidentais, clássicas ou anticlássicas), a fim de dar forma a uma nova experiência do mundo, revela um comportamento que caracteriza, como veremos, boa parte dos movimentos artísticos que surgem na Europa nas décadas de 1910-20, período de formação de Guignard.

\section{A FORMAÇÃO EUROPÉIA DE GUIGNARD}

Guignard se muda com a família (mãe, irmã e padastro) para a Europa em 1907, com 11 anos. Volta definitivamente para o Rio de Janeiro já homem feito e como artista em 1929. Esse longo período, que com certeza teve papel fundamental em sua formação é, contudo, um dos mais nebulosos de sua biografia. Segundo seus depoimentos, o tempo em que freqüentou aulas na Real Academia de Artes de Munique, e posteriormente morou em Florença e Paris, foi somente de estudos e não revela um comprometimento mais engajado 
com nenhuma corrente artística contemporânea. Além disso, o artista não é muito exato com as informações sobre seu passado.

Como entender o peso que ele poderia ter no desenvolvimento ulterior de sua carreira no Brasil? Teria Guignard sido um artista acadêmico que somente descobre tardiamente a arte moderna? O próprio Guignard sugere que uma orientação real em direção à arte moderna só teria se efetivado mesmo no Brasil, conforme afirma em carta enviada ao artista argentino Emilio Pettoruti ${ }^{46}$.

Dar uma resposta definitiva a essas questões dependeria, em última instância, de podermos avaliar um corpo representativo de trabalhos realizados durante sua estadia européia que assinalasse uma fase em sua produção, o que no momento se mostra quase impossível, pois essas obras continuam, em sua grande maioria, perdidas ${ }^{47}$. Mas com algumas informações que conseguimos recolher, algumas considerações poderiam ser feitas em relação ao meio artístico no qual ele se forma e às primeiras orientações estéticas de Guignard que com certeza se fazem observar em suas obras futuras.

Em primeiro lugar, do pouco material conservado e que foi realizado antes de 1929, sobretudo obras em papel, percebe-se que o artista não chega a constituir de fato uma

${ }^{46}$ Guignard conhecera o artista argentino em 1921 ainda em Munique e desde então se tornaram grandes amigos. Em carta escrita em francês, datada de dezembro de 1930, ele afirma: "O ano de 1931 será para mim uma nova Via de realização em pintura, eu quero a força me tornar um modernista, oras! Para isso eu possuo um grande dom de profunda sensibilidade o qual quero aproveitar para realizar definitivamente. Pense como isso é engraçado:

1915 eu aprendi a desenhar em Munique.

1925 eu aprendi a pintura em Florença

e 1930 eu realizei um começo modernista no Rio mesmo.

Como eu estudei bastante na Europa, eu quero realizar agora meus Pensamentos aqui no Brasil mesmo.

${ }^{47}$ Em julho de 1944, a Academia de Arte de Munique foi destruída por um ataque aéreo e seu arquivo, que continha material de seus ex-alunos, aniquilado. Mas é possível supor, por listas de obras manuscritas que encontramos nos arquivos do artista, que muita coisa foi perdida. 
produção acadêmica, apesar de freqüentar as aulas na Academia. Na verdade, Guignard, como é comum entre os artistas modernos, não se forma na Real Academia de Artes de Munique. Segundo o livro de registros, ele teria se matriculado na classe de desenho de Hermann Groeber em 15 de maio de 1916 já com 20 anos de idade ${ }^{48}$. E segundo atestado posterior, teria freqüentado essas aulas nos semestres de inverno e verão de 1916 e 1917, também com o artista Adolf Hengeler. Após a guerra, em 1920, voltaria à cidade e a escola, provavelmente freqüentando a turma de Groeber até 1921.

As aulas de desenho dentro da estrutura acadêmica constituíam-se como estágios preparatórios e probatórios para as classes de composição, nas quais só tomavam parte os alunos mais dotados e depois de alguns anos de treinamento. Em 1911 a academia ganhara uma nova constituição, tornando-se formalmente uma Hochschule (escola superior). Para receber um diploma da Academia era preciso freqüentar as Naturklassen que tinham como tarefa, através do trabalho a partir de modelos vivos, de comunicar aos alunos uma compreensão básica da forma e ao mesmo tempo instruí-los mediante exercício prático na técnica do desenho, da pintura, do modelado ou da arte gráfica. Só então os alunos mais avançados poderiam ser admitidos nas aulas de composição (Komponierklassen), para treinar segundo orientação de professores em projetos e realizações de obras de caráter pessoal. $^{49}$

48 Número da matrícula: 05524. IN: http://matrikel.adbk.de/05ordner/mb_18841920/jahr_1916/

${ }^{49}$ Idade mínima para entrar na Academia era de 14 anos e o curso regular tinha duração de seis anos. 
Não se sabe se por questões históricas, pessoais ou mesmo insatisfação com o ensino, mas o fato é que Guignard não seguira regularmente o curso na academia ${ }^{50}$. É preciso lembrar que entre 1914 e 1918 provavelmente a própria instituição não tenha funcionado de forma regular ${ }^{51}$. Certo também é que durante esse período a arte mais avançada passava longe de suas salas. Se por um lado, a época de ouro da pintura de história, que daria fama internacional à instituição bávara na segunda metade do século 19 sob o comando do pintor Karl von Piloty $(1874-1886)^{52}$ tinha ficado para trás com a

${ }^{50}$ Ao contrário do que afirma Lélia Coelho FROTA, de que Guignard tinha tido sete anos de aprendizado na Academia (p.18).

51 Em sua “Chronik der Akademie der Bildenden Künste München 1770-2008” os professores Walter Grasskamp e Birgit Jooss revelam que durante a guerra alguns espaços da instituição foram apreendidos para funcionamento de repartições militares.

${ }^{52}$ A Academia Real de Artes de Munique foi uma das principais instituições de ensino artístico da Europa no século XIX, pólo de atração para artistas estrangeiros, e teve papel preponderante na construção da imagem de Munique como Kunststadt. Criada propriamente como instituição em 1808, sua origem remonta ao ano de 1766, com a fundação da primeira escola privada de desenho da cidade pelos artistas Christian Wink, Roman Anton Boos e Franz Xaver Feichtmayr, e que passaria a ser subvencionada pelo regente Max III. Joseph em 1770. A escola, que também visava à formação prática, tinha o ensino dividido em duas etapas: o estudo de desenho a partir de modelo vivo e de cópias de gesso de esculturas antigas. Em 1788 ocorre a primeira exposição de 31 alunos da escola na Hofgartengalerie, na qual são mostradas cópias dos mestres antigos. Em 1806, o diretor da Academia de Düsseldorf, Johann Peter Von Langer elabora um plano para a "Academia de Munique" e assume sua direção. Seu projeto pedagógico é considerado extenso, clássico e ideal: uma primeira classe elementar era seguida do aprendizado de desenho através da observação da natureza e de gessos; uma terceira etapa ensinaria a teoria e por fim, no quarto estágio o aluno estaria apto a reunir todos esses ensinamentos para a criação de obras de arte autorais. Apesar da pintura ser visada como o cerne da formação, havia também a previsão de contratação de professores de escultura, gravura e arquitetura, inclusive para as cadeiras de pintura de paisagem e animais.

Em 1807, o filósofo romântico Friedrich von Schelling é nomeado secretário-geral da Academia após fazer um discurso "Sobre a relação entre as artes plásticas e a natureza" no dia onomástico do Rei Max I. Joseph, e cujo conteúdo teria inspirado a primeira constituição extensa e detalhada da "Königliche Akademie der Bildenden Künste München", publicada em 13 de maio de 1808. Por ela são instituídas, juntamente com o departamento de pintura, as seções de escultura, gravura e arquitetura. Ao longo das próximas décadas, para o bem e para o mal, a Real Academia de Belas Artes de Munique permanecerá um estabelecimento palaciano.

Em 1825, o pintor Peter von Cornelius é nomeado seu diretor, dando início a uma era de dogmatismo. Ele defendia uma arte monumental de efeito moral que representasse grandes ideais. Do grupo dos Nazarenos, sob sua direção foram nomeados os seguintes artistas como professores: Julius Schnorr Von Carolsfeld, Heinrich Maria Von Hess, Franz Overbeck, Philipp Veit e Ludwig Schorn para cadeira de história da arte. A exemplo de outras cidades como Düsseldorf e Frankfurt, 
modernização de seus quadros de ensino mediante a nomeação, sob a direção de Ludwig von Löfftz (1891-1899) ${ }^{53}$, de diversos artistas membros da Secessão para professores da

ocupavam agora posições-chave na academia antigos críticos à instituição da tendência Deutschrömer. Como defensor da pintura de história, Cornelius se posiciona contra a independência dos outros gêneros pictóricos, e por isso abole a partir de 1826 o curso de pintura de paisagem. Enquanto a Academia se transforma em um baluarte da pintura monumental de história e da pintura religiosa, a Kunstverein (1823) é fundada como seu pólo oposto, tornando-se um fórum para os assim chamados "Fächler" (ou seja, os pintores de retrato, paisagem, natureza-morta e gênero), que correspondiam ao gosto da burguesia em ascensão. Neste sentido, ela servia a um mercado aberto que se tornou interessante tanto para os diplomados quanto para os professores da escola.

A orientação explícita em direção à arte histórica, cujo instante religioso e nacional é valorizado como o fundo ideal da missão contemporânea da produção artística, continua a ser determinante ainda naquele que seria o mais longo período de um diretor na história da academia de Munique: Wilhelm Von Kaulbach (1849-1874). Apesar de ter assumido seu cargo com promessas de renovação do programa de ensino e mais tolerância, conservou-se a crença no ideal e na norma, na encenação de grandes valores e acontecimentos em nome da educação do povo, assim como nos tempos de Cornelius. É neste período que surge fora de seus muros a discussão sobre a relação entre as artes livres e as artes aplicadas, impulsionada pelo avanço da indústria e pelo sucesso das últimas nas grandes exposições universais. Neste contexto, a sociedade pede reformas no ensino acadêmico, prontamente rechaçadas pela direção.

Sob Kaulbach, o pintor Karl von Piloty é nomeado professor de pintura (1856), e logo sua escola se torna um modelo. Com seu moderno colorismo à francesa, sua capacidade de alcançar efeitos teatrais e seu "materialismo de veludo", ele introduziu um vigor novo e fresco na Academia, o que certamente contribui para que fosse indicado seu diretor em 1874. É também por causa da fama de Piloty, aliada à decadência da concorrente Academia de Arte de Düsseldorf, que se inicia a época de ouro de Munique como lugar de excelência na formação de pintura de história, atraindo estudantes tanto de outros países da Europa quanto da América, o que tornou a cidade bávara a metrópole artística da Europa Central.

É também ainda sob o comando de Kaulbach que se intensificam as exposições de arte, que precisam deixar de ser apenas mostras de prestação de contas dos professores e alunos à sociedade. Na posse de um pavilhão próprio para exposições construído na Konigsplatz, é inaugura por ocasião do jubileu da academia a "Primeira Exposição Geral de Arte Alemã", organizada em conjunto com a Allgemeine deutsche Künstlergenossenschaft (Cooperativa geral de artistas alemães) em 1858, na qual fica patente a querela artística então em voga entre realismo $\mathrm{X}$ idealismo. A segunda exposição internacional, organizada em 1869 pela Kunstlergenossenschaft, conta com a participação de Corot e da Escola de Barbizon, de Milliet e Meissonier, e de sete pinturas de Gustave Courbet. É considerada "a primeira grande exposição internacional em solo alemão". (Cf. Ekkehard MAI. "Problemgeschichte der Münchner Kunstakademie bis in die zwanziger Jahre”, in: Tradition und Widerspruch, pp. 103-143).

53 Segundo Grasskamp/Jooss a Academia vive uma segunda "época de ouro" durante o governo do Príncipe Regente Luitpold (conhecida como Prinzregentenzeit) entre 1886 e 1912. Com estudantes como Joseph Albers, Giorgio de Chirico, Paul Klee, Wassily Kandinsky, Alfred Kubin, Franz Marc, Christian Schad, Max Slevogt, entre outros, ela torna-se um ímã para a geração que deveria fornecer estímulos decisivos para arte moderna (op. cit., p. 541). Contudo, como nota Ekkehard Mai, a partir da década de 1890 Munique irá perdendo gradualmente seu título de Kunststadt para Berlim com o estabelecimento de importantes galeristas no norte da Alemanha e a 
instituição ${ }^{54}$; por outro, como lembra Grasskamp/Joss por volta de 1907, com as nomeações de Hugo Von Habermann, Adolf Von Hildebrand e Angelo Jank são contempladas as posições da Jugendstil, de um moderno Neoclassicismo e de um moderado Impressionismo Tardio e “com isso são também marcadas as fronteiras artísticas que, nas próximas décadas, a Academia não iria ultrapassar”55. Pode-se dizer que os dois professores de nosso artista, Adolf Hengeler e Hermann Groeber, também não transporiam as fronteiras mencionadas acima. Examinando a produção de ambos, vemos sinalizados os limites dentro dos quais ocorrera, na passagem do século, a renovação da Academia Real de Artes de Munique.

Adolf Hengeler (1863-1927) era desenhista satírico e caricaturista que apenas tardiamente se dedicara à pintura ${ }^{56}$. Aluno da instituição bávara na segunda metade do século 19, torna-se conhecido, sobretudo, por sua contribuição ao semanário ilustrado Fliegende Blätter. Segundo crônica artística da época, começa a pintar por volta de 1900 de forma autodidata ${ }^{57}$, influenciado pela técnica de Lenbach e o colorido de Arnold Böcklin e Karl Spitzweg. Suas pinturas revelam uma influência do Romantismo tardio e do estilo Biedermeier cuja filiação será encontrada, além dos artistas citados, em Moritz Von Schwind, Ludwig Richter e no simbolismo de Franz von Stuck.

concentração dos secessionistas nesta cidade a partir de 1898, inclusive com dissidentes da Secessão de Munique, como Lovis Corinth (Cf. “Akademie, Sezession und Avantgarde - München um 1900”, in: Tradition und Widerspruch, p. 172).

${ }^{54}$ Por exemplo, Franz von Stuck (1863-1928), pintor simbolista e membro da Secessão, é nomeado professor da Academia em 1895. No início do século 20, suas aulas serão freqüentadas por P. Klee, W. Kandinsky e J. Albers.

${ }_{55}$ GRASSKAMP; JOOSS, op. cit., p. 542.

${ }^{56}$ As imagens das obras de Adolf Hengeler e Hermann Groeber encontram-se no "Anexo”.

${ }^{57}$ Cf. Richard BRAUNGART, "Adolf Hengeler - zum 50. Geburtstag des Künstlers” e F.v. OSTINI, “Adolf Hengeler”. 
Figuras mitológicas, cenas religiosas ou de contos de fadas germânicos, casais apaixonados cercados por putti e flores em meio a paisagens idealizadas, poetas e pintores observando a natureza e cercados por anjinhos, jovens em vestidos "cujas cores brilham como jóias”, criaturas atemporais em coloridos trajes imaginários, são alguns dos temas que povoam a produção pictórica de Hengeler. Como observa a crítica "nos seus quadros não há realismo exatamente como a Realidade, como a visão normal vê, antes ele compõe uma natureza da maneira como essa é sentida por sua Fantasia, de modo que ela tenha tanto da realidade quanto do caráter ou da essência de Hengeler. E nesta natureza há felicidade e beleza ..."58.

Ao que tudo indica, como pintor se tornou rapidamente tão popular quanto como desenhista e em 1912 é nomeado professor de técnica de pintura (Maltechnik) da Academia. É provável que dele Guignard tenha recebido algumas noções práticas de técnicas de pintura, além das aulas de desenho. No entanto, mediante análise das reproduções de desenhos e pinturas de Hengeler, talvez seja lícito afirmar que sua originalidade e talento estavam realmente ligados a sua produção gráfica de viés satírico e como ilustrador da cultura de sua época. A fantasia e simbolismo de suas pinturas, marcadas por um desenho bastante convencional, possuem um tom edulcorado e algo artificial (que certamente encontravam respaldo no gosto de parcela do público de então). Com elas, Hengeler participa das exposições anuais da Secessão de Munique.

Hermann Groeber (1865-1935) também freqüentou a Academia de Munique na segunda metade do século 19, tornando-se seu professor, primeiro como orientador do

\footnotetext{
${ }^{58}$ BRAUNGART, idem, p. 247.
} 
curso noturno de modelo vivo em 1907, e depois professor honorário de desenho em 1913. As classes de Groeber tinham fama entre os estudantes, pois além de ser conhecido por incentivar a criatividade dos alunos, ele promovia tal convivência de irmandade entre eles (com festas, organização de Carnavais, jantares etc), que acabava gerando o sentimento de pertencerem a uma verdadeira comunidade artística. Um registro dessa relação afetiva com o mestre é a pintura Die Malschüler, 1911, pela qual recebe a medalha de ouro na exposição anual do Glaspalast.

A partir de 1894, Groeber participa de quase todas as exposições anuais organizadas pela Secessão de Munique. Como diversos jovens artistas da Academia, ele contribui no início do século 20 com desenhos e ilustrações para as duas principais revistas ilustradas da época, Simplicissimus e Jugend ${ }^{59}$. Para a crítica da época, Groeber supera o tom escuro da pintura tonal da Escola de Munique para se tornar um pintor da luz. Por seus temas e maneira de pintar é associado ao pintor realista Wilhelm Leibl. Ele se destaca principalmente como retratista e pintor da vida cotidiana do homem do campo bávaro. Em suas paisagens realizadas ao ar livre, percebe-se também influência de um naturalismo com acentos impressionistas, ou seja, uma figuração de cunho realista modernizada pela adoção de uma técnica luminosa que no final do Dezenove se tornara, por toda Europa, índice do “estilo moderno”.

${ }^{59}$ Simplicissimus foi um semanário satírico fundado em 1896 pelo pintor e escritor Albert Langen. Até 1914 apresentou-se como uma revista burguesa democrática sem um programa político orientado e ficou conhecida pela alta qualidade de suas ilustrações e contribuições literárias. No caso de Jugend, fundada no mesmo ano por Georg Hirth e cujo subtítulo era "Revista semanal ilustrada sobre Arte e Vida Cotidiana”, seu estilo deu origem ao termo Jugendstil. A revista cobria moda, vida cotidiana, arte, sociedade e cultura em geral e tinha a intenção de ser "crítica e moderna”. Ambas as revistas serviram como órgãos de renovação das artes gráficas e veículos de promoção da Arte Nova. 
Parece pouco provável que Guignard, para além da instrução prática, tenha sofrido alguma influência mais profunda das obras de seus professores, pelo menos de maneira direta. Entretanto, essas produções revelam não apenas o ambiente no qual ele iniciara seus estudos, mas também um tipo de arte que era bastante popular e aceita pelo gosto médio e pelo meio acadêmico como sendo “moderna”. No caso de Hengeler, uma visão adocicada simbolista-romântica de inspiração pangermânica e de Groeber um estilo pleinairista de temas rurais, de preferência bávaros, que de certa forma denunciam uma modernidade já aclimatada.

Ambos podem ser vistos como membros tardios da Secessão de Munique (1892) ${ }^{60}$. Como observou Maria Makela ${ }^{61}$, duas grandes correntes artísticas caracterizariam a primeira década dos salões deste movimento: nas primeiras exposições predomina o naturalismo lírico em representações de cenas da vida cotidiana, freqüentemente de camponeses e do mundo rural, como na produção de Max Liebermann ou Fritz von Uhde; e na segunda metade de 1890 sobressai a estética de evocação simbolista nas figuras, por exemplo, do melancólico Leopold Von Kalckreuth e nas imagens sinistras e eróticas do já

${ }^{60}$ A Secessão de Munique foi fundada em 1892 por uma minoria de artistas dissidentes da Kunstlergenossenschaft com o objetivo de organizar exposições alternativas às mostras oficiais que ocorriam no Glaspalast. Eles defendiam "a verdadeira arte de todas as tendências” e unicamente a qualidade artística dos trabalhos como critério de seleção para suas exposições, além de manterem o princípio de internacionalidade, trazendo para suas mostras o que havia de mais "moderno" em termos de arte de toda a Europa; eram a favor da igualdade entre belas-artes e artes aplicadas, transformando-se em defensores da Jugendstil em Munique (por exemplo, Richard Riemerschmid foi um secessionista antes de se tornar um dos nomes mais importantes do design e da arquitetura Jugendstil). Em meados de 1890, a arte secessionista começou a ganhar contornos mais claros em suas divergências com relação à arte acadêmica: "liberdade na forma e na cor, impressões frescas, gestos naturais, a natureza em si mesma e não segundo composições estabelecidas, desenvolvimento do talento sem o espartilho da história e do modelo, caracterizariam a pintura secessionista”. (Cf. Ekkehard MAI, “Akademie, Sezession und Avantgarde - München um 1900”, p. 162.).

${ }^{61}$ Maria MAKELA, The founding and early years of the Munich Secession, pp. 159-160. 
citado Franz von Stuck. Um importante subgrupo revelaria a "quintessência” da estética secessionista: o "simbolismo naturalista" em paisagens ou cenas da vida cotidiana, investidas de conteúdos psicológicos ou emocionais.

De maneira geral, os movimentos secessionistas, como observou G. C. Argan, são caracterizados por um "modernismo moderado" que determinou, paralelamente ao Impressionismo francês, uma cultura figurativa européia na passagem entre os séculos 19 e $20^{62}$. Além disso, Makela nota que desde o seu início o agrupamento de Munique é especialmente marcado por um espírito mais conservador. Do ponto de vista técnico, por exemplo, os artistas alemães mesmo pintando ao ar livre ou alla prima ainda estão preocupados com o desenho e o modelado, e ao invés de expressarem a luz natural pela justaposição de manchas de cor, sua luminosidade "impressionista” é alcançada com a tradicional adição de branco em seus pigmentos. Mas o mais significativo são as diferenças temáticas, pois os naturalistas germânicos estão focados quase sempre em temas rurais e os simbolistas evitam manifestações de angústia, preferindo evocar sentimentos menos poderosos por meio de um lirismo inspirado pela natureza e por temas ligados à Arcádia e a Mitologia $^{63}$. Depois de 1900, os salões secessionistas vão cada vez mais perdendo seu vigor

${ }^{62}$ G. C. ARGAN, Arte moderna, p. 212.

${ }^{63}$ A autora mostra que também com relação à representação da arte estrangeira em seus salões, a Secessão apresenta um perfil mais contido, não se interessando em expor, até pelo menos 1900, os impressionistas e pós-impressionistas mais radicais, além de ignorar o simbolismo tortuoso de Ensor e Munch, dando preferência a artistas como Arnold Böcklin ou o naturalismo lírico da Escola de Hague. Por isso, já em 1894 artistas como Lovis Corinth, Max Slevogt e Wilhelm Truebner rompem com a Secessão e fundam a Freie Vereinigung. Mas Makela ressalta que a preferência destes secessionistas pela evocação lírica, em oposição à expressão direta e poderosa, e seu apreço por temas rurais no lugar de cenas da vida moderna urbana, não é apenas uma recusa provinciana, mas parte de uma tradição que alcança seu resultado mais brilhante no lirismo otimista da Der blaue Reiter. (Cf. MAKELA, op. cit., pp. 162-166). 
e apenas diferem em termos numéricos do salão oficial organizado no Glaspalast pela Münchner Künstlergenossenschaft ${ }^{64}$.

Sendo assim, como outras instituições acadêmicas oficiais espalhadas pela Europa, também a Academia de Artes de Munique passa por um processo de "renovação" ou “liberalização” pressionada certamente pela perda de hegemonia em seu papel social de reguladora das normas artísticas e de cultivadora do gosto, introduzindo em seu ensino alguns “avanços” identificados a um “estilo moderno”, e com isso ampliando os limites de seu padrão estético. Porém, essa “abertura” não representa propriamente uma reforma, na medida em que mantém certas premissas, sobretudo aquelas relacionadas à qualidade técnica e artesanal do ensino artístico e à superioridade da tradição da arte culta, ou "belasartes”.

Evidentemente, não é apenas na Academia que Guignard educa seu olhar e encontra referências artísticas. Mesmo que após 1919, com a repressão violenta à breve Räterepublik e o período politicamente conturbado do pós-guerra na Alemanha, marque o início de uma época culturalmente conservadora em Munique, é muito provável que ele trave contato, ainda que superficialmente, com as novas vertentes artísticas.

Nas primeiras duas décadas do século 20, a promoção da “nova arte” deve-se essencialmente a atuação de duas galerias em Munique: a partir de 1909 a Moderne Galerie de H. Thannhauser, e de 1912 a Neue Kunst Galerie de Hans Goltz. Ambas foram

${ }^{64}$ A partir de 1917, as exposições da Secessão não são mais internacionais e se dedicam basicamente a mostrar os trabalhos da geração de seus fundadores e nomes ligados a eles. Paul Klee que havia exposto pela primeira vez suas gravuras na mostra de 1906 como aluno de Franz Von Stuck, escreve em seu diário em 1912: "Ah, a Sezession! Por mais que se prove que estão ultrapassados, eles não vão acreditar” (Diários, p. 301). Em 1913 ele participa, juntamente com A. Jawlensky, A. Kanoldt e outros da fundação da Münchner Neue Sezession. 
indispensáveis para o desenvolvimento e promoção de importantes movimentos de vanguarda na Alemanha e de seus artistas, como o grupo Der blaue Reiter, como foram responsáveis por organizar importantes mostras de artistas estrangeiros, apresentando ao público alemão a arte de vanguarda internacional que se produzia naquele momento. Por exemplo, em 1913, a Moderne Galerie, cuja exposição de abertura havia mostrado artistas impressionistas e pós-impressionistas, organizou a primeira retrospectiva de Picasso em solo alemão e introduziu ao público da cidade os futuristas italianos.

No caso da galeria de Hans Goltz, além das exposições conjuntas de artistas fauves e expressionistas, da última exposição do grupo "O Cavalheiro Azul” (da qual participam, além de seus fundadores, nomes como Derain, Hans Arp, Picasso, Braque, Delaunay, Wlaminck e Larionov), promove importantes mostras como a retrospectiva de Paul Klee (1920), individual de George Grosz (1920), de Kurt Schwittres (1921), retrospectiva de Alfred Kubin (1921), Otto Dix (1922), “A nova arte gráfica da Bauhaus” (1923), uma retrospectiva Lovis Corinth (1924), individual de Carl Mense (1925), El Lissitzky (1926) entre outras, na qual são contempladas as mais diversas tendências contemporâneas. Também é pelas mãos de Goltz, através de sua livraria, que penetra na Alemanha as idéias da revista "Valori Plastici” (1918-1921) ${ }^{65}$. Em suas páginas, futuros representantes da “Nova Objetividade” alemã entram em contato com a "Pintura Metafísica” pelas reproduções de obras e ensaios de Carrà, De Chirico, De Pisis, Morandi, Savinio entre outros, num encontro que será determinante para o retorno à imagem realista de artistas que

${ }^{65}$ Cf. Schmied, Wieland. "L'histoire d'une influence: Pittura metafisica et Nouvelle objectivité”, In: Jean CLAIR (org.). Les Réalismes 1919-1939, p. 20. 1981; p. 20. 
em meados dos anos 1920 irão se opor ao pathos expressionista, à desconstrução cubista, à abstração e à antiestética dadaísta ${ }^{66}$.

Da mesma maneira, é na visitação às coleções públicas que Guignard entra em contato com os antigos mestres que naquele momento estavam sendo revalorizados pela nova geração de artistas na Alemanha, como Altdorfer, Grünewald, Holbein e Dürer. Como vimos por suas entrevistas posteriores, não raro ele coloca no mesmo patamar artistas tão distintos como Giotto, Botticelli, Da Vinci, Tintoretto, Pieter Brueghel, Rembrandt, Velazquez, Goya, Ticiano, Gainsborough, Hodler, Rousseau, Van Gogh, Matisse, Dufy entre outros, numa seleção que parece sugerir uma espécie de simultaneidade entre eles, provavelmente da mesma forma que o artista entra em contato com produções tão diversas.

Não encontramos nenhum registro (anotações, estudos, releituras) das séances de Guignard na Alte Pinakothek de Munique. Contudo, uma parcela dos artistas citados como referência por ele está muito bem representada neste museu que desde o século 19 é um dos mais importantes da Europa ${ }^{67}$. É possível identificar a experiência que ele teve desses artistas, em sinais que persistem posteriormente em sua própria obra, como por exemplo, da pintura de paisagem flamenga, da qual a Pinacoteca possui uma enorme coleção.

Trata-se de pequenas paisagens montanhosas de Jan Brueghel ou de Joos de Momper, que foram fundamentais para constituição e popularização desse gênero a partir do século 17, e que têm sua origem no trabalho de Pieter Brueghel, o Velho [figs. 11 - 16].

\footnotetext{
${ }^{66}$ Sem esquecer que vários artistas da Neue Sachlichkeit são egressos desses movimentos, como Otto Dix, Max Beckmann, Georg Grosz e Christian Schad.

${ }^{67}$ Em resposta ao questionário Krebbs, Guignard cita algumas coleções públicas nas quais teria estudado: o Louvre, em Paris; a Pinacoteca, de Munique; a Kunsthalle de Hamburgo; Albertina Museum, de Viena; a Galeria Uffizi e o Palácio Pitti, em Florença (resposta 15).
} 
Essas pinturas se destacam pela fatura lisa, pelo contraste entre as figuras muito próximas em primeiro plano, desenhadas com um pincel bem fino e às vezes também na forma de notação $^{68}$, e a vista distante ao fundo, intensificando a percepção de profundidade espacial. E também pelo recurso a certo "encobrimento" das figuras representadas ao longe como forma de reforçar essa mesma profundidade. Seus horizontes altos são dominados por paisagens montanhosas que caracterizam a Überschaulandschaft (Paisagem panorâmica) e pela perspectiva empírica e muitas vezes aérea cuja ilusão de profundidade é construída a partir da utilização do "esquema clássico de três cores” e suas tonalidades intermediárias (tons castanhos para o primeiro plano, verde para o plano intermediário e azul para o fundo). Em comparação com a "paisagem de horizontes planos”, popularizada pela pintura holandesa na segunda metade do século 17, essas pequenas telas parecem ser tocadas por um certo mistério e drama que posteriormente irão reaparecer nas cadeias de montanhas da paisagem romântica e sua correspondente concepção de sublime. E de certa maneira, nas populares paisagens dos Alpes cultivadas por muitos artistas da Secessão, inclusive Hengeler, tornando-se quase um gênero pictórico à parte.

${ }^{68}$ Como lembra ARGAN, "Brueghel é o primeiro pintor que desenha com o pincel, como fariam mais tarde Rembrandt, Franz Hals e Vermeer”, Clássico anticlássico, p. 467. 


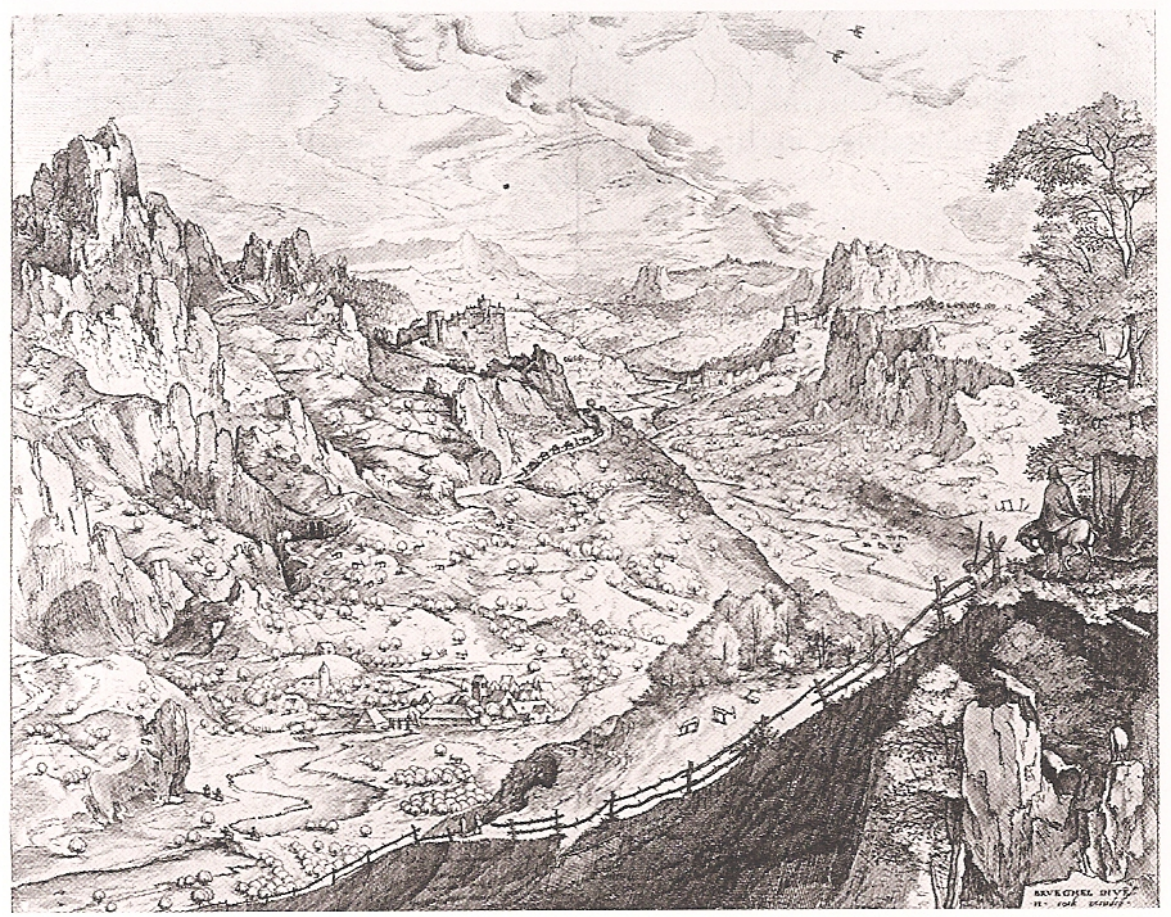

FIG. 11 - P. BRUEGHEL, GROSSE ALPENLANDSCHAFT, S. D

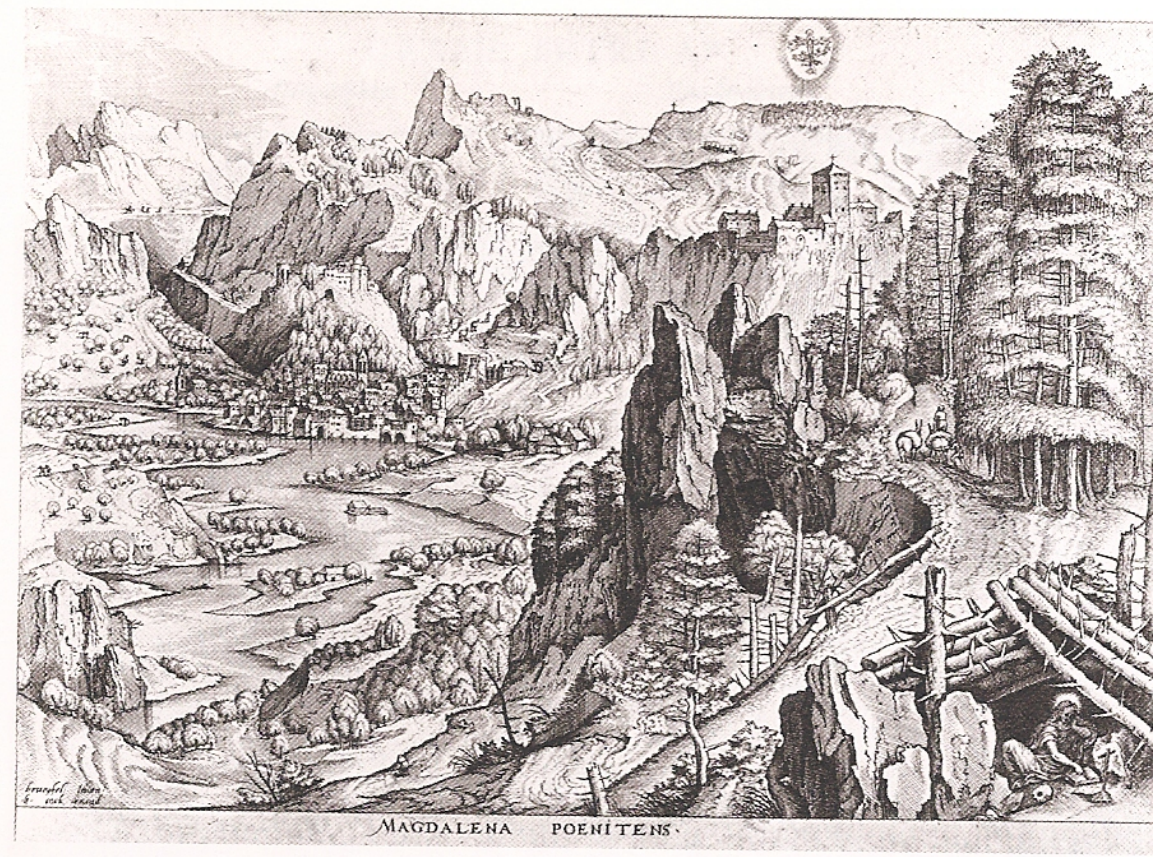

FIG. 12 - P. BRUEGHEL, MAGDALENA POENITENS, S.D 


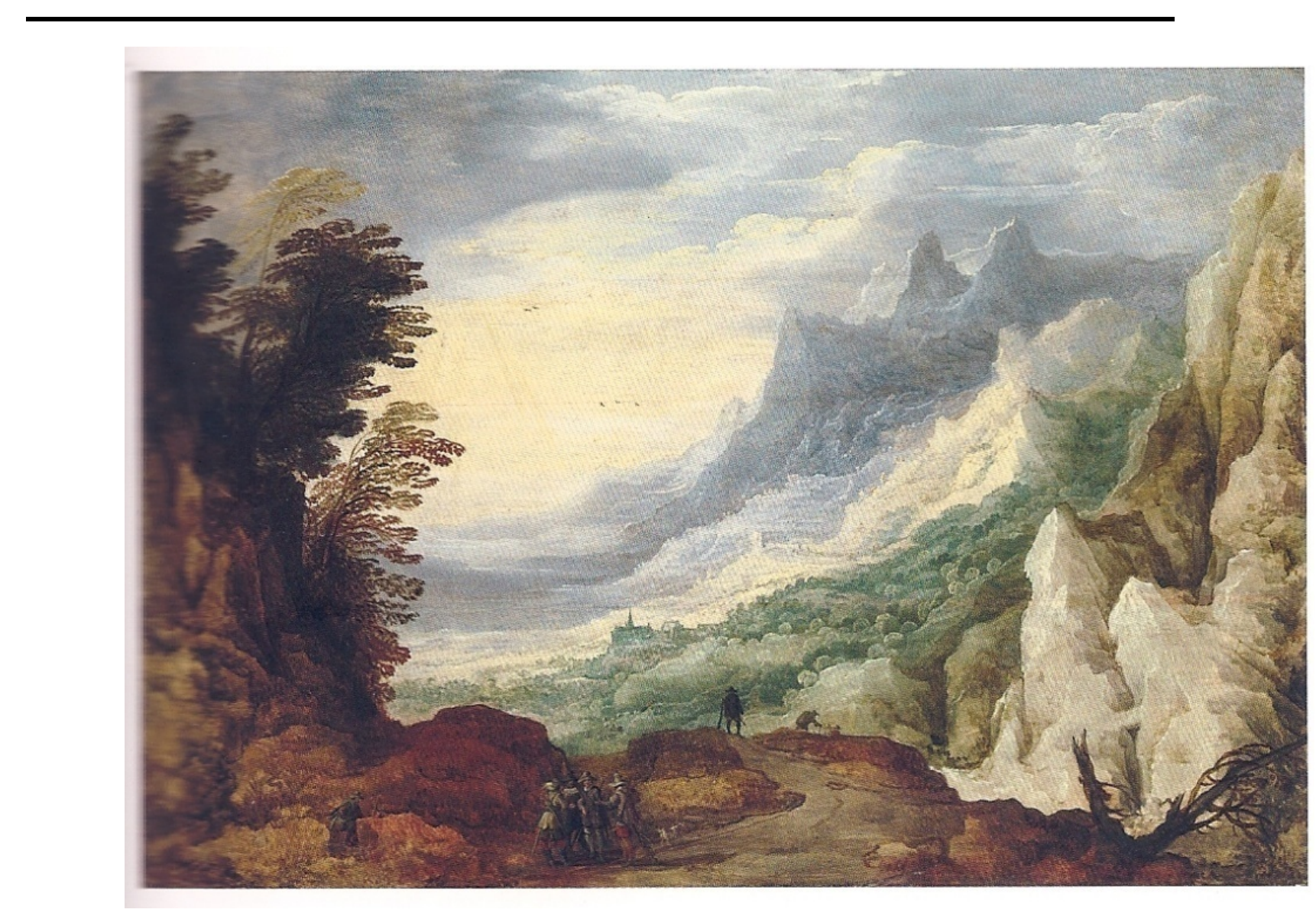

FIG. 13- JOOS DE MOMPER, FELSLANDSCHAFT MIT BLICK AUF EINE KIRCHE IM TAL, C.1620/30 


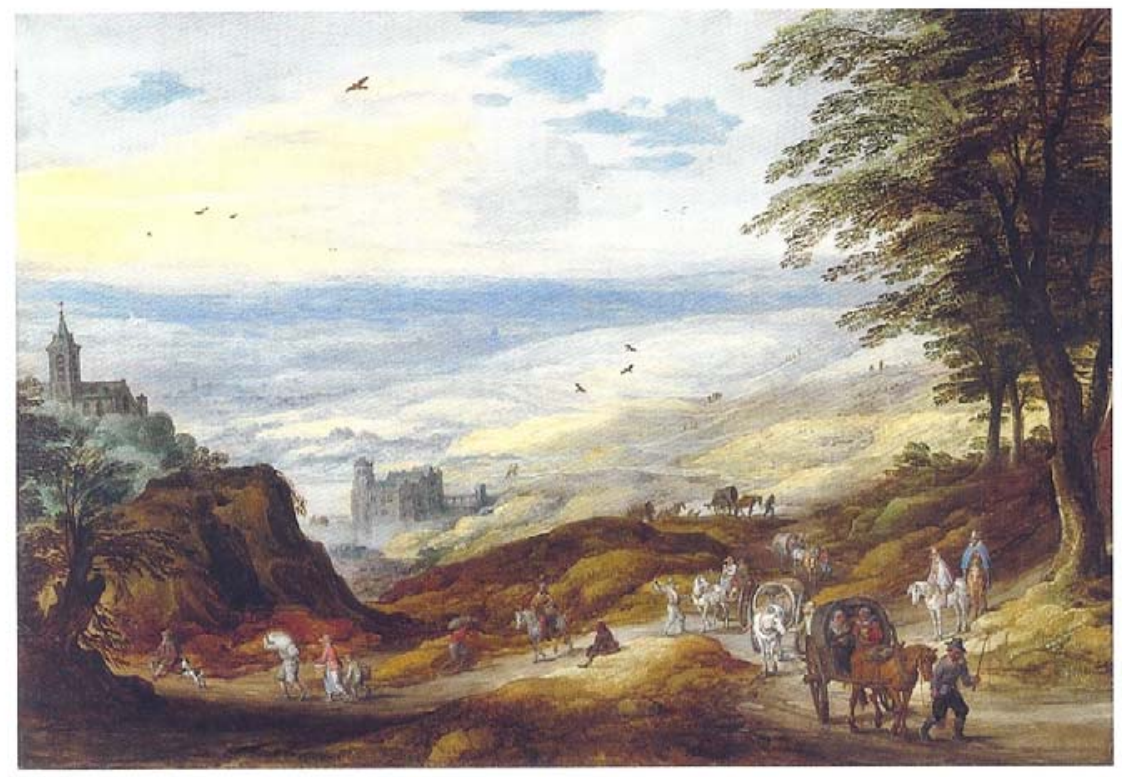

FIG. 14 - JOOS DE MOMPER E JAN BRUEGHEL, LANDSCHAFT MIT FERNSICHT, C. 1610/15

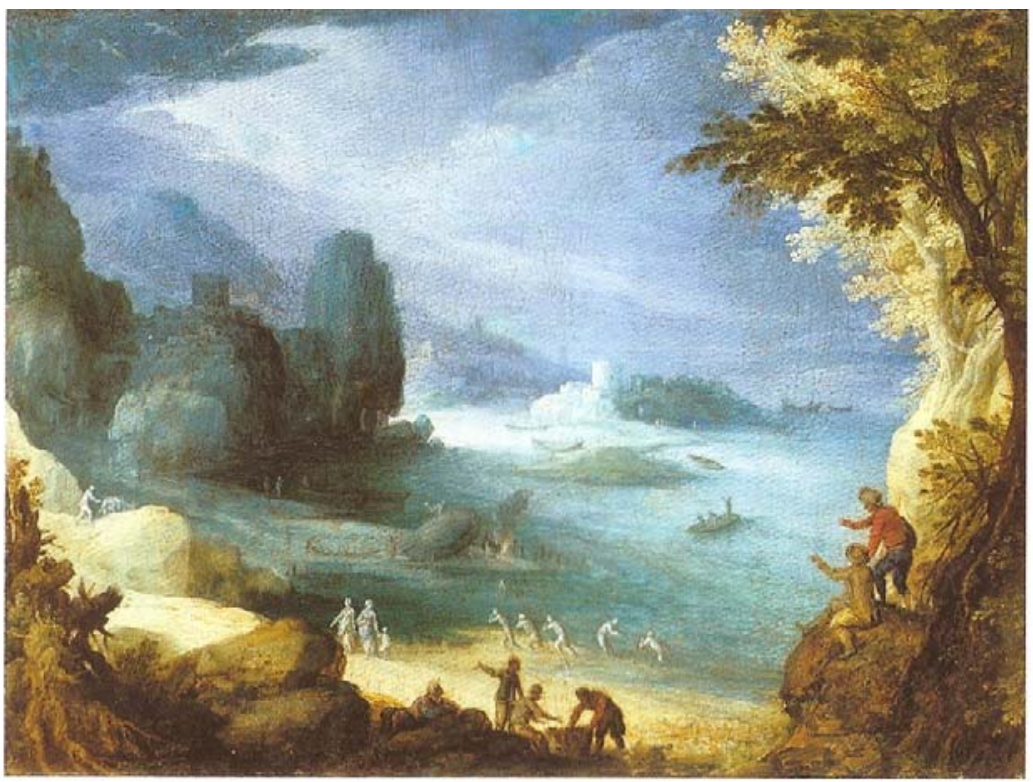

FIG. 15 - PAUL BRIL, LANDSCHAFT MIT AUSBLICK AUF EINE MEERESBUCHT, C. 1595 


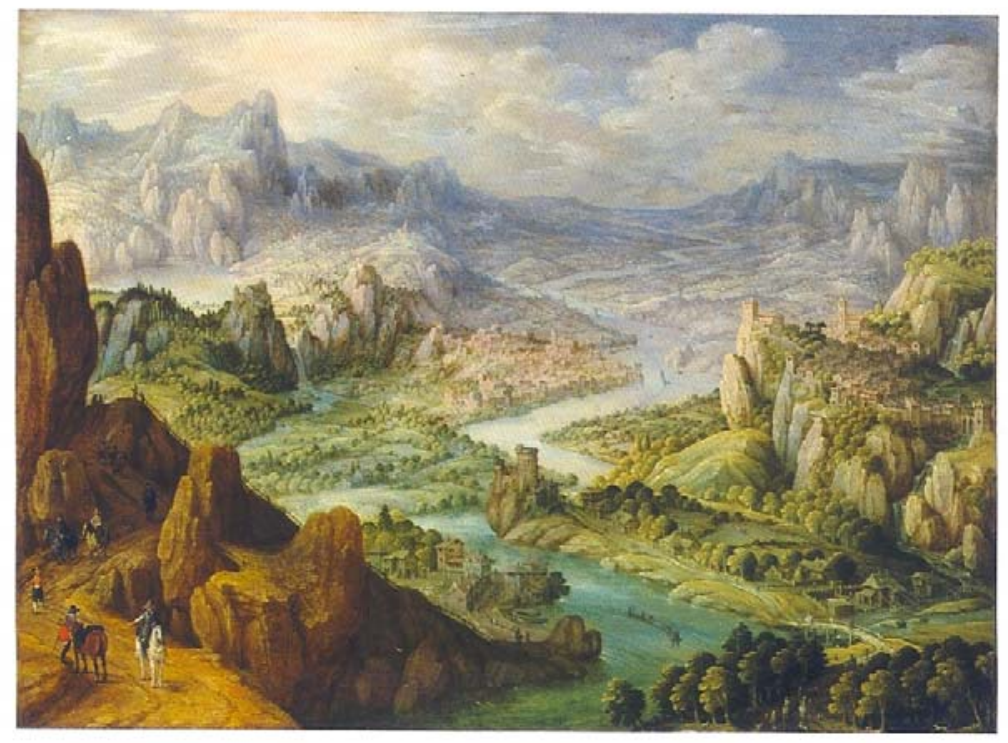

FIG. 16 - TOBIAS VERHAECHT, FELSLANDSCHAFT, 1612

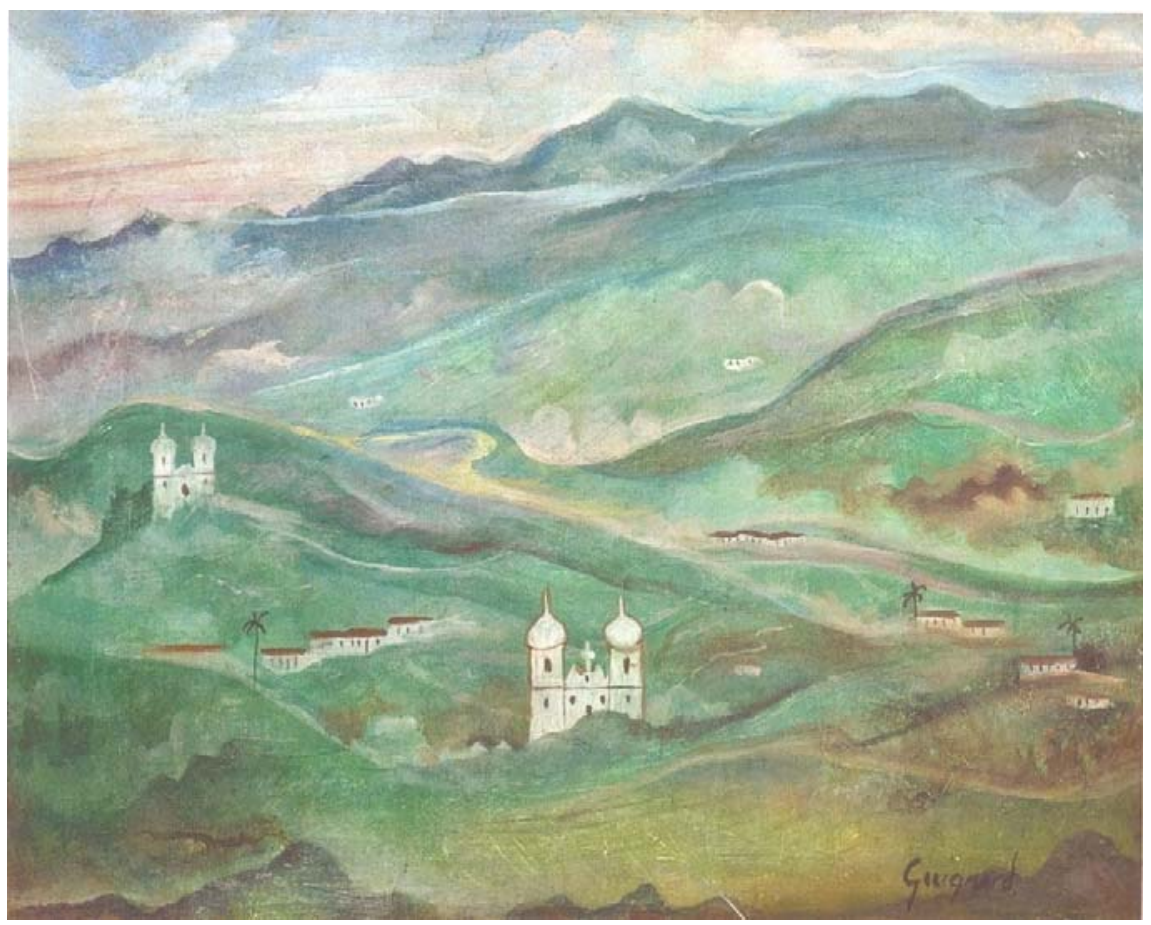

FIG. 17 - PAISAGEM DE MINAS, 1940 (ÓLEO SOBRE TELA, 32 X 40 CM) 
Não apenas os fundos montanhosos verde-azulados de alguns retratos pintados por Guignard parecem conter obliquamente reminiscências dessas pinturas, como o já citado retrato de Felicitas Barreto [fig. 8], mas também suas primeiras paisagens "imaginantes" e suas vistas de Itatiaia e Minas da década de 1940 em diante [fig. 17]. Voltaremos a essas relações mais tarde. Por ora, notamos que a maneira "miniaturizada” como Guignard trabalha muitos dos seus elementos em primeiro plano, sejam arquitetônicos ou humanos, contrapostos às paisagens montanhosas de limites indefinidos ao fundo, parecem querer alcançar a mesma sensação de intimismo e proximidade provocada pelos artistas flamengos, como se a experiência do inapreensível de repente se tornasse concreta e por isso, compreensível. Por isso, é provável que Guignard não tivesse se dedicado com tanto interesse às paisagens montanhosas que encontrou no Brasil, se não conhecesse toda essa tradição ${ }^{69}$.

Ao mesmo tempo, ainda em Munique ele teve a oportunidade de entrar em contato com uma importante coleção de arte européia dos séculos 18 e 19 na Neue Pinakothek, apesar de não se referir tão pontualmente a este museu. Sob a direção de Hugo Von Tschudi a partir de 1909, este museu adquire pinturas, esculturas e desenhos de expoentes do chamado "Moderno clássico" (klassische Moderne), que a definem como um dos

${ }^{69}$ Em seu texto notável sobre a origem da pintura de paisagem intitulado "A teoria renascentista da arte e a ascensão da paisagem”, E. H. GOMBRICH mostra como no caso da apreciação da paisagem como um gênero autônomo houve um importante movimento que foi da teoria à prática e desta à idéia de belo natural. Sendo que "para o pintor, por sua vez, nada pode tornar-se um motivo, exceto aquilo que ele pode assimilar ao vocabulário que já domina” e assim, "se Pieter Brueghel de fato achava inspiradores os picos dos Alpes, era porque a tradição da arte desses mestres provera-os com um símbolo visual propício à representação de rochas íngremes, permitindo-lhes apreciar essas formas na natureza”, in Norma e forma, p. 154. 
principais acervos públicos de arte moderna naquele momento ${ }^{70}$. É por isso que ao lado de artistas como Goya, Caspar David Friedrich, Gainsborough, Turner, Constable, Lovis Corinth, Odilon Redon, entre outros, Guignard tenha tido um primeiro contato com a pintura impressionista e pós-impressionista francesa ainda durante seus primeiros anos de estudo na Academia mediante essa importante coleção pública.

A comparação entre dois auto-retratos do artista confirma sua aproximação à expressividade moderna ainda nos anos 20. O primeiro, um desenho de 1919 [fig. 18], nos confronta com o Guignard-aluno da academia. Ainda que executado de forma primorosa, chamando a atenção pela acuidade da observação e pela expressividade da linha, este autoretrato em carvão conserva-se dentro dos padrões do naturalismo acadêmico. O traço forte tem a capacidade de realçar características marcantes da cabeça do artista, além dos olhos, como os cabelos, as sobrancelhas arqueadas, as orelhas, o queixo e o lábio leporino, dotando a figura como um todo de um caráter pujante. Seu volume é alcançado mediante o jogo habitual de luz e sombra.

O segundo trabalho, a aquarela ${ }^{71}$ Sem título, de 1924 [fig. 19], que hoje é reconhecida como sendo também um auto-retrato, indica sua familiaridade com certo estilo expressionista tardio (ou "realismo expressionista", como era caracterizado esse tipo de trabalho na época). Sem realmente se aprofundar em deformações ou em contrastes de cores fortes e saturadas, seu traço caligráfico, sua sobreposição de tons sombrios (que de

${ }^{70}$ Entre eles citam-se obras de Manet, Monet, Renoir, Van Gogh (Vista de Arles, 1889 e Girassóis, 1888), Cézanne (Natureza-morta com cômoda, 1883/87), Matisse (Natureza-morta com Gerânios, 1910) e Gauguin (Camponesas bretãs, 1886 e Paisagem de Martinica, 1887).

${ }^{71} \mathrm{O}$ trabalho, que pertence à coleção de Ângela Gutierrez (BH-MG) foi identificado apenas como aquarela. Contudo acreditamos que outros materiais foram utilizados pelo artista pelos traços que se deixam entrever por baixo, como grafite e lápis de cor. 
certa forma servem para tornar baço o desenho que se apresenta embaixo) e a transparência pictórica característica ao meio, remete a um clima de decadência e mal-estar fin-de-siècle que o aproxima em seu caráter fantasmagórico e evocativo ao realismo simbólico de James Ensor e Edvard Munch, por exemplo, ou ao subjetivismo dramático de Van Gogh ${ }^{72}$. Vestido como um dândi (talvez fantasiado), sua individualidade melancólica, e um tanto perturbada, é expressa pelo embaçamento do desenho e a dissolução dos limites da figura. Sendo que aqui o contraste entre tons claros e escuros reforça a impressão geral de melancolia. Do mesmo ano é a aquarela Sem título [fig. 20], na qual também o desenho a lápis é sobreposto pela transparência da aquarela com a função de dissolver seus limites, dando à figura o aspecto vivaz do inacabado.

${ }^{72}$ Notamos, entretanto, que Guignard não pode ser considerado "expressionista” no sentido estrito do termo (tomando-se como referência o Expressionismo alemão). E apesar de admirar por toda vida Van Gogh, suas telas mais expressionistas trazem uma temática religiosa que o aproxima antes dos trabalhos tardios de Lovis Corinth, que como outros pintores sob o impacto do fim da Primeira Guerra Mundial, volta-se para representação de temas cristãos em um estilo expressionista matizado, mas nem por isso menos interessante (cf. por exemplo a tela O Cristo vermelho, 1922). 


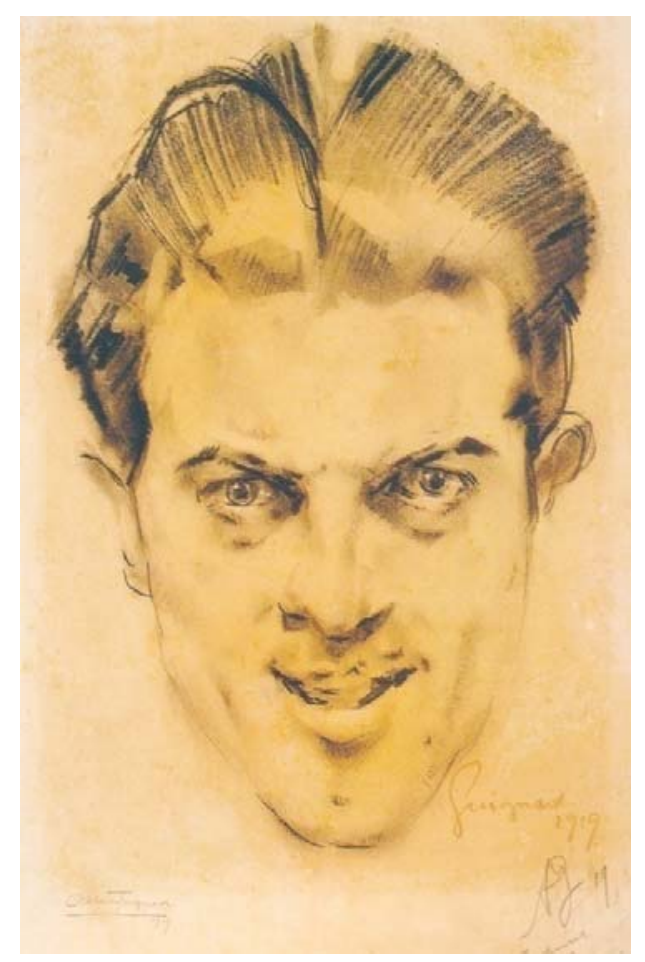

FIG. 18 - AUTO-RETRATO, 1919

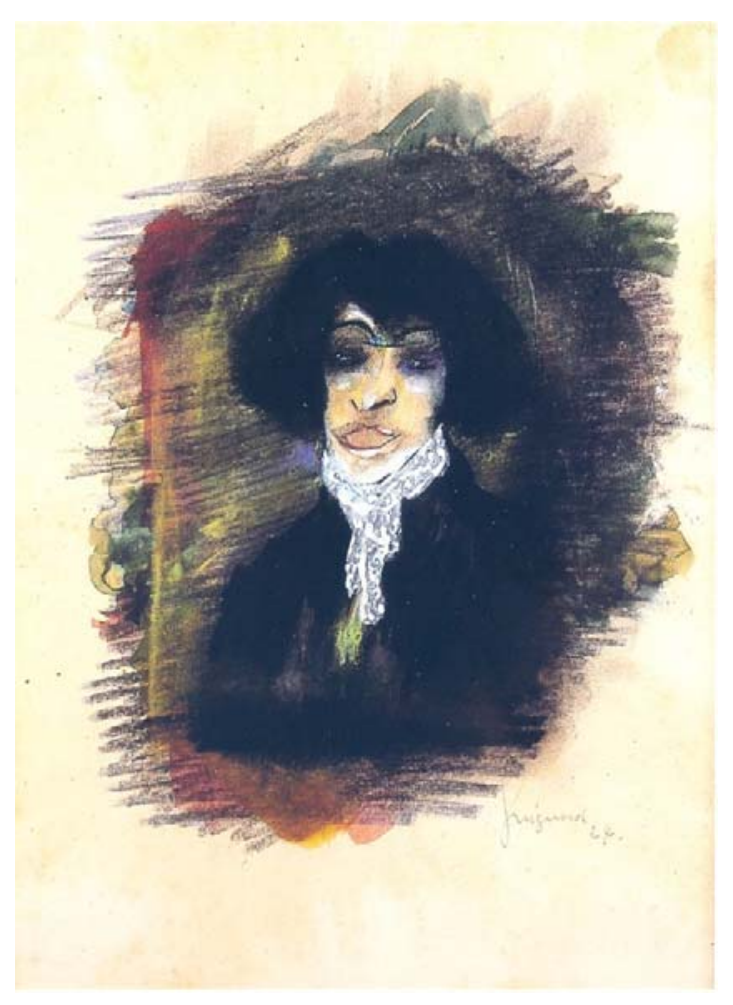

FIG. 19 - SEM TÍTULO, 1924 


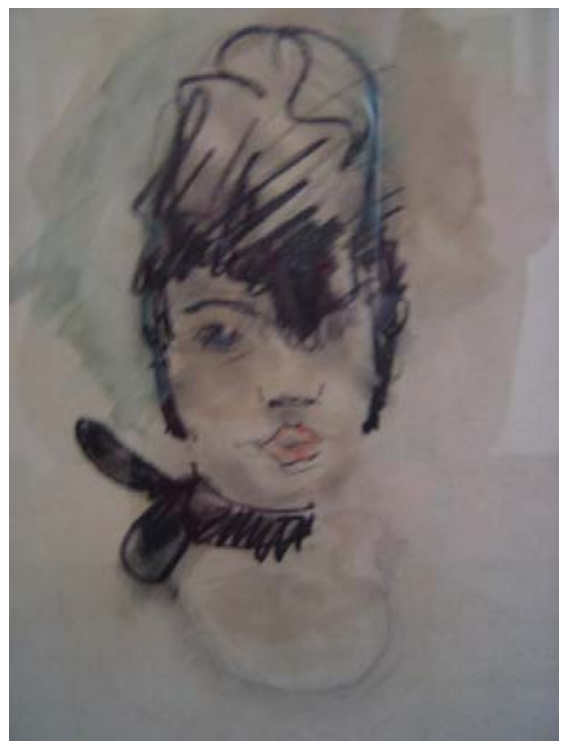

FIG. 20 - SEM TÍTULO, 1924

Guignard começa a expor na década de 1920, o que pode então ser considerado o início de sua carreira profissional. Sua primeira participação se dá no salão anual do Glaspalast em Munique, em 1923, com dois desenhos. Na seqüência ele vem para o Brasil e expõe no XXXI Salão Nacional de Belas Artes, no Rio de Janeiro, no qual recebe menção honrosa de segundo grau. Segundo o catálogo, participa já como ex-aluno da Academia de Belas Artes de Munique, apresentando um Auto-retrato em pastel, talvez o mesmo analisado acima, além de cinco desenhos. Neste momento tenta se estabelecer como professor no Brasil, mas acaba voltando para Europa, fixando-se em Florença no final de 1924.

No ambiente cultural altamente ambíguo e complexo da nascente República de Weimar (1919-1930), em que à volta à figuração responde tanto a tendências políticas de 
esquerda quanto de direita, e que ao mesmo tempo testemunha o nascimento de uma das mais importantes experiências estéticas do século com a criação da Bauhaus (1919), é significativo que Guignard, ele também, se volte para a Itália e a tradição renascentista, referindo-se a esse período "pós-acadêmico” de sua formação como sua fase de libertação.

\section{VOLTA À FIGURAÇÃO E A TRADIÇÃO.}

Se por um lado, Guignard sofre alguma influência do simbolismo de acento lírico, que era uma corrente modernista importante na Alemanha da passagem do século, como revelam suas telas do início dos anos 30, como Santa Cecília (a santa padroeira da música) ou Glória do artista, por outro, ele está a par das novas correntes artísticas do pós-guerra que foram marcadas por um ímpeto geral de volta à figuração ${ }^{73}$. Esses movimentos, que se deram de modo simultâneo em diversos países e que ficaram conhecidos sob o lema generalizante “rappel à l'ordre”, são vistos hoje por alguns críticos e historiadores como

${ }^{73}$ Guignard participa em 1928 da XVI Esposizione Internazionale d'Arte della Città di Venezia como jovem artista que teve seu trabalho Retrato do Barão von Schilgen (obra perdida) escolhido por um júri formado por Felice Casorati, Napoleone Martinuzzi, Mario Sironi, Ardengo Soffici e Antonio Maraini. Dentro os expositores, encontram-se artistas ligados a essa tendência como Medardo Rosso, Carlo Carrà, Pio Semeghini, Marino Marini, Giorgio Morandi, Alberto Magnelli, Fillipo de Pisis, Mario Tozzi etc. Há ainda mostras especiais sobre a Escola de Paris (organizada por René Paresce) e o Futurismo Italiano. No pavilhão francês ocorre uma retrospectiva de Paul Gauguin e mostras individuais de Henri Matisse e Antoine Bourdelle; no alemão, mostras individuais de Lovis Corinth, Franz Marc e Emil Nolde, além de sala geral de pintura com Beckmann, Otto Dix, Kirchner, August Macke, Karl Schmidt-Rottluff, Georg Schrimpf, Max Pechstein e Paul Klee; da Holanda vem Mondrian, presente com Composição, 1914 e Composição, 1921. 
um capítulo de reação antimodernista no interior da própria modernidade ${ }^{74}$. Concorde-se ou não com esta opinião, o fato é que essa "volta” corresponde a um posicionamento legítimo diante de um momento de crise no interior da história da própria pintura moderna, pois para esses artistas não era viável admitir que após a experiência limite do espaço cubista só haveria como via a seguir a abstração ou a arte não figurativa, o construtivismo ou a atitude drástica de desconstrução dadaísta.

Entretanto, por mais que este movimento geral possa ser identificado por uma busca comum de retorno a uma figuração de origem clássica, ele adquire feições particulares em cada um dos países no qual ocorre. Por exemplo, se no caso da França trata-se de uma volta ao purismo racionalista da tradição francesa, a fim de afastar o barbarismo da influência germânica, no caso dos italianos busca-se o reencontro com a tradição renascentista italiana e a afirmação de sua superioridade e papel fundador na história da arte. Já na Alemanha, se os estudos clássicos e a viagem à Itália estão novamente na ordem do dia entre os artistas da Neue Sachlichkeit, também se defende a retomada da precisão e objetividade dos velhos mestres alemães paralelamente à tradição da pintura romântica, no lugar do Neoclassicismo francês.

É por isso que em relação à arte dos anos 1920 é preciso falar em Realismos, na medida em que os retornos às inumeráveis tradições nacionais respondem a objetivos

${ }^{74}$ Como Yve-Alain Bois que vê neste retorno apenas um "conservadorismo cínico" diante da institucionalização da arte de vanguarda pelo mercado que tem como marco o ano de 1915. Eu cito: "Na verdade, essa posição cínica foi assumida por aquilo que é conhecido como retorno à ordem, que começou em 1915 com Retrato de Max Jacob, de Picasso, mas que se tornou um fenômeno maciço na década de 1920 com a Pittura Metafísica, na Itália e a Neue Sachlichkeit, na Alemanha ("Pintura: a tarefa do luto", in: A Pintura como modelo, p. 286). Ou o capítulo sobre Picasso em 1919 e o legado do Cubismo em Art since 1900: modernism, antimodernism, postmodernism (volume 1 - 1900-1944), p. 160-165. 
diversos $^{75}$. Neste sentido, em meados desta década o debate não se dava em torno do "a favor ou contra" a volta à imagem realista e à tradição, mas sim sobre o que é o realismo e qual tradição ou momento dela valorizar. E por isso, são admitidas nesta tendência artistas tão diversos quanto Amedeo Modigliani, Balthus, Picasso, André Derain, Max Beckmann, Christian Schad, Mario Tozzi, Carlo Carrà, entre outros.

Há então múltiplos usos do termo “clássico” que irão gerar uma noção "flutuante” de classicismo moderno ${ }^{76}$. Visualmente há tanto um renascimento literal de temas, tipos e formas antigas, o que produz por vezes um classicismo retórico de tipo arcaico dentro da tradição figurativa do século 19, quanto o apelo ao "elemento clássico” da arte ocidental que seria definido, por um artista como Giorgio de Chirico, pelo “demônio da linha, quer dizer, essa finesse e pureza da sensação linear que consegue captar os signos misteriosos e profundos nos mínimos aspectos da natureza"77.

Assim mesmo que pela noção de “clássico” Guignard não esteja se referindo a algo muito específico, ao dar seu depoimento no final dos anos 1940, contudo podemos supor que sua permanente referência aos artistas “antigos” também participe desse movimento de

${ }^{75}$ Ou como bem notou Christian DEROUET, "cada um fazia, da herança dos velhos mestres, mel à sua maneira" ("Les Réalismes en France: rupture ou rature”, in: Les Réalismes 19191939, p. 200. Aliás, sobre este assunto, é essencial a consulta a este catálogo organizado por Jean Clair com textos de diversos autores sobre os "diferentes" retornos em países ou mesmo continentes distintos.

${ }^{76}$ Cf. Pia VIVARELLI, “Classicisme et arts plastiques en Italie entre les deux guerres”, in Les Réalismes, p. 61.

${ }^{77}$ Idem, p. 60. Como observam Charles Harrison e Paul Wood em Art in Theory 19002000: an anthology of changing ideas, p. 14, "a reavaliação crítica da tradição européia foi em geral um aspecto importante das primeiras vanguardas do século 20 (...). Assim, por exemplo, a compreensão de‘classicismo'foi divorciada por Maurice Denis e Roger Fry de sua associação tradicional a um cânon literário ou assuntos mitológicos e reinterpretada em apoio aos compromissos evidentes da arte moderna: por um lado, significa a concentração do sentimento original em forma visual, por outro, sugere que a busca por tal concentração tem sido uma preocupação persistente da tradição ocidental”. 
época, o que de certa forma explicaria sua estadia em Florença. Neste discurso o clássico estaria relacionado, como observou José Augusto Ribeiro, a “uma dimensão permanente da arte”, a algo intemporal. $^{78}$

De par com isso, talvez a fala de Guignard ecoe algo que os artistas de sua geração viram em Cézanne, aquele cuja produção também foi decisiva para esse movimento de “volta à ordem”: a tentativa de fazer coexistir o impulso romântico e o equilíbrio clássico, ou seja, ainda o problema do subjetivo e do objetivo. Como apontou Argan, sua “classicidade pura” reside no fato de que "não há uma ruptura entre a realidade interna e externa: a consciência está no mundo e o mundo na consciência”. ${ }^{79}$

Como já foi feito, é licito apontar na produção de Guignard dos anos 20-30 afinidades pontuais a artistas dessa tendência. No caso da arte contemporânea alemã, com aspectos do "Realismo mágico", como se sabe, uma das vertentes da Neue Sachlichkeit que teria se desenvolvido particularmente em Munique com uma produção de acentos românticos - em parte influenciada pela Pintura Metafísica e pelas tendências surrealistas de Alexander Kanoldt, Carlo Mense e Georg Schrimpf.

Em diálogo constante com a fotografia, sabe-se que o retrato foi um dos gêneros mais importantes para os artistas da Nova Objetividade. Em pinturas como Retrato de

${ }^{78}$ Ribeiro, José Augusto. Guignard e o ambiente artístico no Brasil nas décadas de 1930 e 1940. Dissertação de mestrado, São Paulo, ECA-USP, 2009. P. 24.

${ }^{79}$ Assim "o pintor, portanto, representa não a realidade como ela é, nem como a vemos sob o variado impulso dos sentimentos, mas a realidade na consciência ou o equilíbrio absoluto, finalmente alcançado, entre a totalidade do mundo e a totalidade do eu, entre a infinita variedade das aparências e a unidade formal do espaço-consciência” (Arte moderna, p. 113). Lembramos que para o crítico e historiador italiano, a cultura artística européia da primeira metade do século 20 "gravitará em torno dos dois termos opostos do dilema e de sua relação dialética cada vez mais tensa: Cézanne ou Van Gogh, clássico ou romântico, Impressionismo e Expressionismo”. 
mulher, 1922 de Schrimpf nota-se o mesmo espírito de objetividade e distanciamento que caracterizaria, por exemplo, os retratos fotográficos de August Sander. Trata-se de São quadros marcados pelo estatismo frontal da figura, pelo enquadramento paralelo à base, o colorido "retido" e transparente, a fatura lisa, sem traços do pintor e sem emoção aparente. Muitas vezes a profundidade sugere uma flutuação de perspectiva e um espaço/tempo nãodeterminado que em contraposição à proximidade da figura originaria, a despeito da objetividade da representação, uma sensação de estranhamento. E neste sentido, muitos desses retratos parecem se inspirar nas modernas técnicas de fotomontagem. Assim o tratamento realista das figuras e do espaço é investido de uma atmosfera fantástica de tons melancólicos, em que o motivo ganha aspectos estranhos e misteriosos ${ }^{80}$.

Guignard, cuja produção de retratos foi bastante numerosa (como atesta imagem de sua primeira individual no Brasil, organizada pela Pró-Arte em 1931 em que são expostos basicamente retratos), em algumas de suas composições parece atraído pela atmosfera fantástica gerada pela contraposição entre o estatismo frontal das figuras e a imagem que lhe serve de fundo. Entretanto é preciso notar que raramente ele adota a volumetria da forma, o detalhismo realista e a racionalidade espacial da perspectiva geométrica, como a maioria dos artistas, não apenas alemães, que propõe a volta às regras de composição da arte clássica neste momento. E neste sentido, se a tela Auto-retrato, 1931 (Col. MAC-USP) sugere também uma influência dos retratos de Giorgio de Chirico dos anos 20, ao mesmo tempo está longe da organização geométrica espacial e da figuração realista-metafísica do

${ }^{80}$ Segundo Franz Roh, o Realismo da "Nova Objetividade" estaria a meio caminho dos pólos da Abstração e da Einfühlung tal como definidos por Wilhelm Worringer: “o realismo mágico pode ser definido como a interpenetração das duas possibilidades (...) uma tensão delicada, mas constante, entre o abandono ao mundo existente e uma vontade evidente de construir a ele se pondo". (Les Réalismes, p. 147). 
artista italiano, pois já neste quadro observamos sua preferência pelos fundos em verdeacizentado cuja profundidade obedece a efeitos de transparência a partir da sobreposição de uma palheta em tons rebaixados, o linearismo a retirar parte do volume dos corpos e o decorativo do pulôver que remete a qualidades puramente pictóricas da composição.

Por isso é que, se parte do interesse de Guignard pela tradição da pintura ocidental pode ser compreendido dentro desse contexto mais geral da arte do pós-guerra, há algo aqui que já se busca como uma solução pessoal, como parte de sua poética. Num primeiro momento, o que Guignard parece querer aprender dos antigos mestres, para além do próprio aprendizado do métier da pintura, é uma expressão sintética da linha que irá caracterizar seus trabalhos, principalmente nos anos 20 e 30, e que seria paradoxalmente uma maneira de se opor ao ensino do desenho acadêmico. Esse "sentimento da linha" mostra-se na obra de Guignard basicamente de dois modos: ora é a linha fluida e espessa, por vezes ligeiramente desenhada com cor e que em seu inacabamento sugere um ritmo vibrante; ora se apresenta como um fino traço preto, como contorno fechado, quase como um sulco na superfície, indicando tanto contornos precisos quanto uma divisão planar do espaço e seus elementos decorativos. De ambas os modos, essa linha revela uma vontade de expressar os elementos do mundo visível em formas sintéticas e segundo uma noção rítmica do espaço que afastam a arte de uma concepção puramente naturalista.

Como observou o historiador Roberto Longhi ${ }^{81}$, a corrente linear assume maior força na pintura italiana entre final do Trezentos e o Quatrocentos, atingindo seu apogeu na obra de Sandro Botticelli (1444/5-1510). Da linha gótica-floral de Duccio (1260-1339), de

\footnotetext{
${ }^{81}$ Roberto LONGHI, Breve mas verídica história da pintura italiana.
} 
origem grega, passando pelo floralismo de Simone Martini (1285-1344), pela vitalidade expressiva da linha funcional de Andrea Del Castagno (1421 ca. -1457) e Antonio Pallaiolo (1420-98), e chegando ao ritmo total de movimento de Botticelli, o que se observa, segundo o autor "é um modo de visão pelo qual o artista figurativo exprime toda a realidade visual sob a forma de linhas e contornos”. Ainda segundo ele, esses artistas, ao buscarem eliminar do complexo das aparências tudo aquilo que não se pode exprimir por intermédio de linhas, encontram-se o mais longe possível de qualquer realismo.

Guignard também parece ter sido sensível a esse "sentimento linear" que caracterizaria a arte dos artistas ditos “primitivos"82 e que, como notou Lionello Venturi em seu estudo fundamental sobre o tema intitulado $O$ gosto dos primitivos, não por acaso escrito em 1926, é uma das chaves para compreensão da arte moderna. Os antigos primitivos italianos, cuja revalorização no século 19 e 20 encontra sua origem no pensamento do crítico inglês romântico John Ruskin - o qual via no êxtase a condição da arte e a essência do processo artístico na "adesão mística” à natureza - teriam na inspiração o ponto de partida para criação artística, no lugar da imitação preconizada pelo gosto clássico. Neste sentido, suas obras apresentam “de maneira direta, com linhas, formas e cores, e não pela mediação da natureza, todos os sentimentos humanos e revelando-os diretamente, os exalta, os faz intensos, universais, eternos”33. É com essa liberdade de

${ }^{82} \mathrm{O}$ que segundo os historiadores compreende os artistas italianos que viveram entre o século o final do 13 até o final do 15, entre Cimabue e Botticelli

${ }^{83}$ Lionello VENTURI, El gusto de los primitivos, . p. 189. 
evocação, na qual os símbolos plásticos ao sintetizarem mais revelam do que representam, que os artistas modernos teriam se identificado ao redescobrir os artistas primitivos ${ }^{84}$.

É evidente que Guignard não chega à linha rítmico-decorativa de Botticelli, por exemplo, sem ter visto, mesmo que parcialmente, toda uma "tradição moderna” que vinha desde o simbolismo, passando pela Jugendstil, até Gauguin, Van Gogh e Matisse, para a qual o desenho da linha na superfície, associada a certas estilizações e distorções e a ausência de perspectiva aparecem como índice de um primitivismo decorativo, tomado aqui em seu mais alto sentido ${ }^{85}$. E lembramos que para esses artistas essa "expressão primitiva” poderia ser buscada nas fontes as mais diversas: na arte italiana do Quatrocentos, na gravura japonesa de um Hokusai, na arte popular da Bretanha, na arte do Islã, no Taiti e assim por diante. Guignard, que como sabemos no futuro terá sua obra associada às simplificações de uma pintura popular, com certeza era consciente deste movimento e de sua correspondente associação entre linguagem "primitiva” e “moderna”.

Mas voltando a permanência de Guignard em Florença como um momento importante para a compreensão da constituição de seu gosto artístico, é notável que ele se dirija a Botticelli. Pois para além da importância que a linha decorativa enquanto andamento rítmico e musical tem para o estilo do mestre italiano, parece que ele foi

${ }^{84} \mathrm{E}$ aqui cabe observar que para Venturi os verdadeiros primitivos modernos seriam os impressionistas, Manet, Cézanne e os pintores macchiaoli como Fattori, e não, por exemplo, os artistas Pré-Rafaelistas ou os italianos ligados à volta à ordem, exatamente porque revelam uma “alma primitiva” sem ter propriamente assimilado a arte primitiva (idem, p. 209).

${ }^{85}$ Como observa Gill PERRY em "O primitivismo e o 'moderno'” (in Primitivismo, cubismo, abstração: começo do século XX), há no final do século 19 "um importante conjunto de associações entre os conceitos de primitivo, de simbolista e de decorativo". Por exemplo, para o crítico simbolista George Albert Aurier "a pintura decorativa em sentido próprio, como os egípcios e, muito provavelmente os gregos e os primitivos a entendiam, não é outra coisa senão a manifestação de uma arte ao mesmo tempo subjetiva, sintética, simbólica e ideísta” (idem, p. 21). 
sensível à “composição em superfície” - ou seja, a maneira de situar as figuras em um continuum espacial, sem escaloná-las, mas alinhando-as “num espaço breve e indefinido”, como observou Argan ${ }^{86}$ - que caracteriza a pintura do artista renascentista e cuja atitude

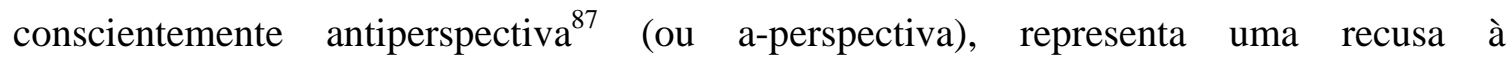
racionalidade do naturalismo clássico e seu excesso de realismo.

Como notou Argan, Botticelli desenvolve em suas pinturas a figuração numa dimensão irredutível a um espaço e a um tempo concretos. E nisso reside o caráter idealista de sua arte. Construída essencialmente por ritmos lineares, elas suscitam um dinamismo ascendente, um movimento sem fim, no qual o olho é impedido de se fixar em uma forma determinada, situada em um espaço tridimensional facilmente reconhecível. Ao mesmo tempo, outro dado fundamental de seu estilo é a maneira como ele resolve o problema da luz no sentido "espiritual” da transparência ou diafaneidade. Com isso, os corpos em seus trabalhos não têm espessura nem volume, e por isso se transformam em imagens ou símbolos, de modo que a arte permita "descobrir os significados alegóricos ocultos nas coisas naturais”. Assim o processo artístico não realiza uma transposição, mas uma transfiguração ou sublimação do objeto mediante o mais imaterial e intelectual dos signos, a saber, a linha - ainda que o objeto, por isso mesmo, permaneça como algo incondicional $^{88}$.

${ }^{86}$ G. C. ARGAN, “Botticelli”, in Clássico anticlássico, p. $238 .$.

${ }^{87}$ No sentido de que ele não aceita as regras da perspectiva como princípio fundamental para a construção da visão.

${ }^{88}$ De resto, lembro aqui de uma importante associação feita por Argan em seu estudo no sentido de indicar a relação de Botticelli com a arte moderna: "É uma maneira nova de compor, não mais por equilíbrio e simetria de formas ou por combinação de figuras, mas por uma coincidência, uma contraposição, um somatório de ênfases expressivas; uma maneira certamente antiperspectiva e antiespacial, que realmente declara a decadência de todo naturalismo compositivo e antecipa a 
Translucidez, imaterialidade dos corpos, tratamento rítmico do espaço, simplificação e decorativismo linear, indeterminação espaço-temporal são alguns dos elementos facilmente identificados à poética de Guignard nos anos que se seguem a sua “formação". Toma-se como exemplo dois retratos do final dos anos 20/ início dos 30: o primeiro datado de 1929 do pintor Emilio Pettoruti [fig.21], provavelmente pintado ainda na Europa, o outro do poeta e amigo Murilo Mendes [fig. 22], talvez um dos primeiros realizados no Brasil, de 1930. Em ambos o traço preto surge em toda sua capacidade sintética, e que aliada à transparência da cor e a predominância de cores frias, atribui ao conjunto uma impressão geral de diafaneidade e uma atmosfera de evocação. Ambos os artistas, amigos próximos de Guignard no período, parecem se transformar em figuras quase incorpóreas, no limiar entre a fisicalidade da matéria e sua total transcendência.

composição por tensões interiores (...). É claro então que a poética de Botticelli não é apenas um recuo artístico deliberado, mas também uma abertura indireta para a arte moderna: não, certamente, para a arte de 'visão' que, a partir de Leonardo, através dos venezianos, dos flamengos e dos espanhóis, chegaria aos impressionistas; mas para a arte de 'expressão' que, através dos alemães, chegará até o Expressionismo” (op. cit, p. 221). 


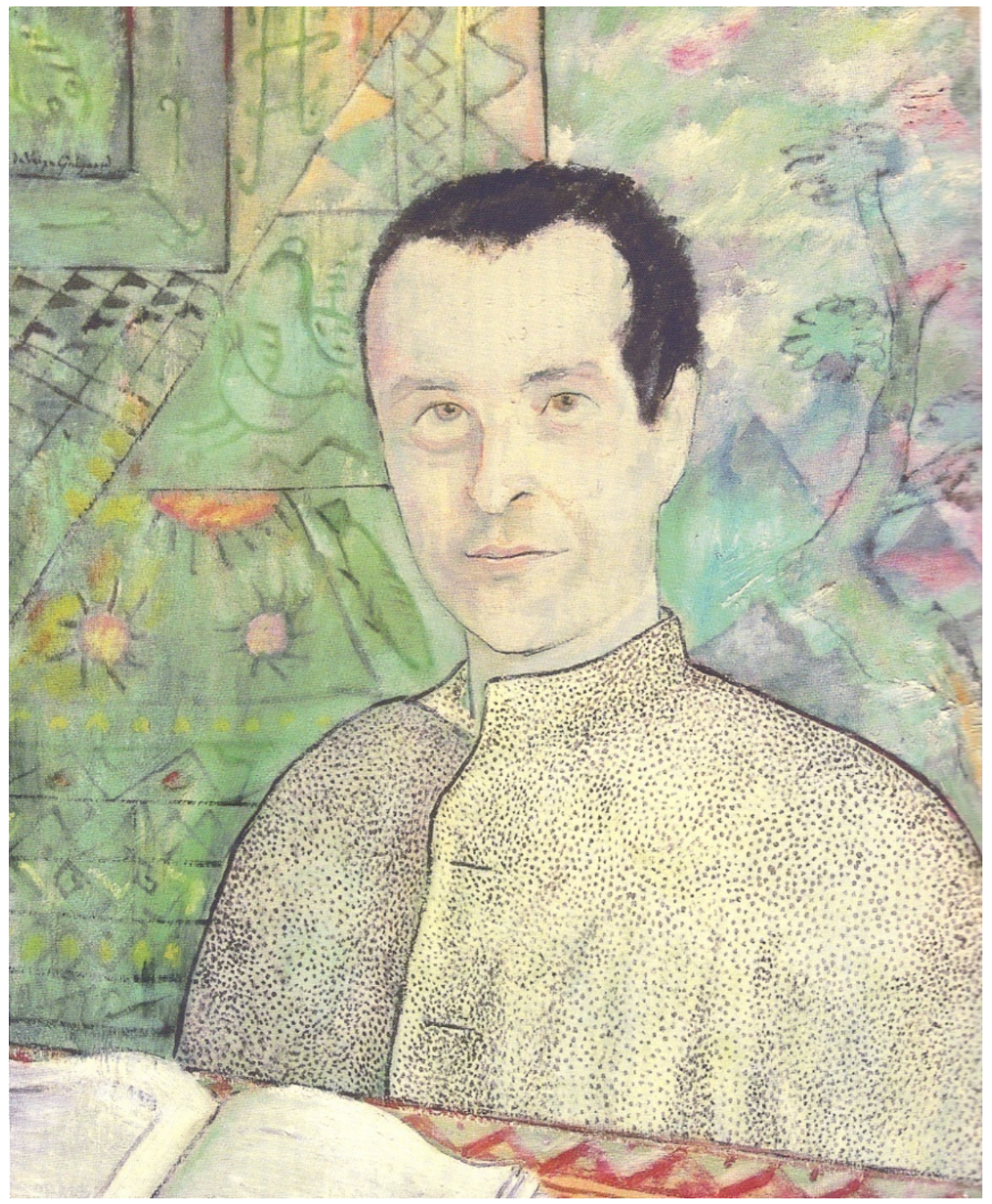

FIG. 21 - RETRATO DE EMILIO PETTORUTI, 1929 (ÓLEO SOBRE TELA, 54 X 42 CM)

Além disso, o tratamento bidimensional que Guignard dá ao espaço afasta essas representações de qualquer intenção realista. No caso de Retrato de Pettoruti, de um dos lados do fundo do quadro, a figura do artista entra em fusão com signos gráficos que parecem indicar o universo particular da imaginação do pintor (e ao mesmo tempo evocam elementos puramente decorativos, quase simbólicos), o que se confirma pela presença de uma tela recortada no canto superior esquerdo que na verdade indica uma continuação do 
espaço entorno (e na qual curiosamente encontramos a assinatura “Da Veiga Guignard”). Do lado direito, forma-se um espaço ambíguo em que a composição em manchas de cor sugere a impressão de “quase” abstração que é desfeita pela visão do esboço de um tronco de árvore diante de uma paisagem ao fundo, em que o cume das montanhas é levemente delineado com uma sombra cinza azulada e as nuvens por pinceladas brancas.

Há aqui uma intenção clara de distinção entre um exterior e um interior espacial, marcado inclusive por uma linha vertical que segue a sugestão de profundidade do recorte oblíquo do tampo da mesa na base do quadro e a direção de outra linha diagonal que corta seu canto esquerdo. Contudo, trata-se de uma profundidade que não se realiza como tal nem pela paisagem, cuja fusão entre céu e terra dá idéia de uma espessura espacial que tende a superfície (recurso que como sabemos, será característico da poética guignardiana); nem pela separação definitiva entre dois planos.

Logo, o que se percebe é uma passagem permanente entre o exterior/interior, o espaço da subjetividade e à referência ao mundo “real”, entre a profundidade tridimensional e a planaridade bidimensional da pintura, com a figura íntegra do artista como elo entre eles. E é notável que diante da ambigüidade espaço-temporal, a figura humana permaneça claramente definida em seus contornos, como aquilo que unifica a significação do todo.

Por sua composição e paleta predominantemente esverdeada, o que confere ao conjunto um forte tom melancólico, mas também um caráter etéreo, esse retrato parece antecipar à fase dita “surrealista” de Guignard. De alguma maneira, ele contém um simbolismo no qual o mundo da imaginação, neste exemplo representado por um artista 
específico, entra em fusão com o mundo “objetivo”. E claramente o livro aberto sobre a mesa é um indício da capacidade intelectual do artista ${ }^{89}$.

No caso do poeta Murilo Mendes, como se sabe um dos amigos de Guignard logo quando este chega no Rio, a ambiguidade entre interioridade e mundo exterior é marcada pela existência de uma janela que enquadra, de maneira irreal, um ícone da paisagem tropical. Os tons azulados utilizados para pintar céu, mar e morros investem a paisagem de um caráter tristemente onírico, como se esta também estivesse sendo "vista” através dos olhos do poeta.

O recurso ao panejamento das cortinas nas laterais serve, ao mesmo tempo, como elemento de passagem entre exterior e interior, mas simultaneamente trazem a imagem para superfície, tornando o espaço mais plano. O campo negro, entre o tecido do lado direito e o limite da janela, reforça a sensação de “inadequação” das proporções e nos leva a indagar se na verdade essa paisagem também não é um quadro na parede, de tão oblíqua e próxima que está. Há aqui também a sugestão de uma profundidade que não se realiza, ou melhor, permanece num limiar.

${ }^{89}$ É interessante notar que parte das obras consideradas “surrealistas” de Guignard, realizadas nos anos 30, apresenta temas ligados às artes ou aos artistas, como Glória do artista e Santa Cecília, ambas de 1933, ou ainda a peças musicais como Noturno de Borodine de 1937. O que indica, de certa maneira, uma associação entre o ato de criação artística e uma esfera sobrehumana ou sobrenatural. Em anotações manuscritas pertencentes ao arquivo do Museu Casa Guignard, encontramos o seguinte pensamento datado de 1952: “O verdadeiro artista é guiado por um poder celestial”. 


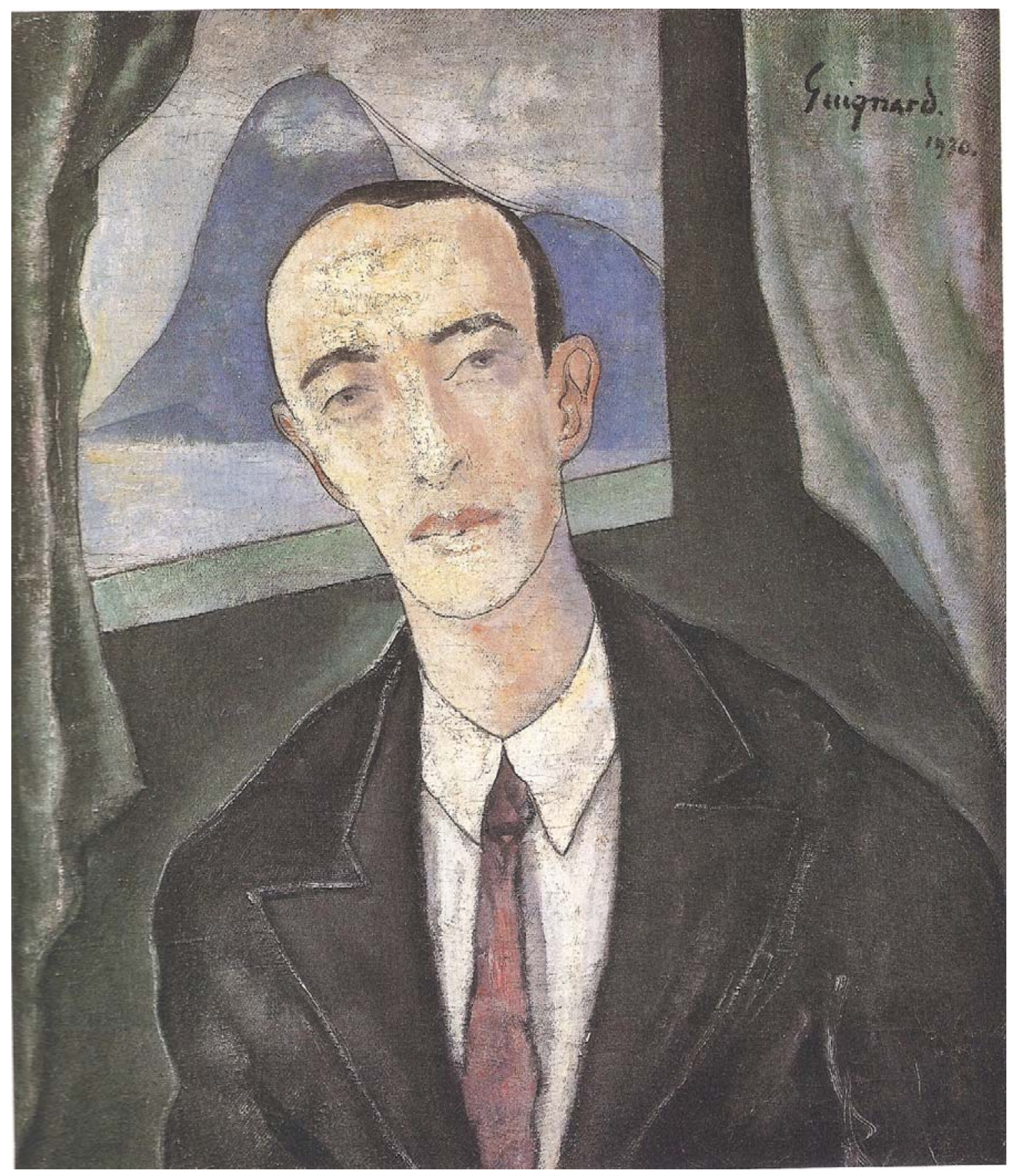

FIG. 22 - RETRATO DE MURILO MENDES, 1930 
A tonalidade sombria do interior é interrompida pela luz que emana da pele e da camisa do poeta e desliza como uma espécie de halo em torno da figura. Há todo um deslocamento do mundo visível que atinge seu ápice na seriedade melancólica do rosto, cuja natureza sugere algo de incorpóreo. A linha "achata" os volumes dos corpos e das coisas, ajudando a construir um espaço que se dá pela continuidade de planos tendentes à superfície $^{90}$. Há uma interação entre sujeito e objeto em um espaço irreal, a exemplo do que ocorre nos sonhos.

Logo a adoção ao sintetismo linear também em Guignard responde ao desejo de ir além da simples representação fiel do mundo sensível, tal como provavelmente teria aprendido na Academia. Assim como no trabalho de outros artistas que souberam encontrar a grandeza expressiva dos primitivos, ele parece ter intuído nesses mestres uma concepção de arte que buscava, mesmo que mediante uma linguagem figurativa, desprender-se da percepção puramente retiniana, e encontrava na atividade artística o poder de instauração de uma "supra-realidade”, não limitada pela imitação do real.

E é por isso que essa oscilação entre o objetivo e subjetivo, a evocação de um mundo paralelo, na fronteira entre o real e o onírico (ou ideal), será uma ocorrência freqüente na obra de Guignard e não apenas na sua fase dita "surrealista”. Tanto em seus retratos, como em suas melhores paisagens e naturezas-mortas, a indefinição do espaço freqüentemente é contraposta a uma notação linear sintética das figuras em proximidade,

${ }^{90}$ Em outro Retrato de Murilo Mendes, de 1931, Guignard repete a solução espacial do retrato de Pettoruti de forma invertida, com a parede e o quadro do lado direito (no caso, coloca uma pintura de Ismael Nery) e a paisagem à esquerda com uma linha vertical a separar exterior/interior e a imagem do artista no centro, numa desproporção que indica novamente ambiguidade espacial. 
sugerindo a intersecção dos planos e ao mesmo tempo mantendo a espessura de um fundo que se nega à profundidade projetiva da perspectiva geométrica tradicional.

Se de um lado ele não passa incólume ao idealismo de Botticelli e outros primitivos italianos, de outro se compreende a referência constante a outro “antigo mestre”, Leonardo da Vinci. Do ponto de vista histórico seria incoerente juntar a produção desses dois artistas, posto que o último representa, no contexto geral da história da arte, a antítese do primeiro ${ }^{91}$. Contudo, Guignard entrevê na perspectiva aérea de Leonardo da Vinci um estímulo à construção de uma espacialidade condizente com as flutuações e inconstâncias dos fenômenos. Além disso, parece que há uma atração natural do artista pela dimensão fantástica que os fundos das pinturas do italiano criam ${ }^{92}$. Em certos momentos, ele revisita literalmente alguns dos temas caros ao pintor renascentista, como o estudo e representação dos diversos estados físicos da água pelo qual da Vinci era fascinado ${ }^{93}$, e que se manifesta em céus brumosos, na condensação das nuvens, em cascatas e rios que parecem erodir as montanhas numa osmose de água e pedra - toma-se como exemplo o biombo pintado já no final de sua vida intitulado Homenagem a Leonardo da Vinci (1959).

${ }^{91}$ Como observa ARGAN nos ensaios "Botticelli” e “5 daaghossto 1473” (in: Clássico anticlássico), a arte da visão e da investigação fenomênica de Leonardo da Vinci é a antítese histórica do platonismo contemplativo e do idealismo de Botticelli, e marca o início de uma nova era.

${ }^{92}$ Como nota GOMBRICH (op. cit., p. 147) Leonardo da Vinci teria inventado a primeira teoria estética completa da paisagem, mesmo antes desta ter existido quando ele no Paragone afirma "Também está em seu poder (do pintor) criar os vales que deseja admirar, os picos das montanhas sobre as quais pode avistar vastas regiões de terras e olhar para o mar no distante horizonte, para além delas; e também, se quiser, admirar as altas montanhas a partir dos vales profundos, ou das altas montanhas os vales profundos e os contornos da costa. Na verdade, tudo que existe no mundo, virtual ou concretamente, ou na imaginação, ele pode ter, primeiro em sua mente, depois na mãos...”.

${ }_{93}$ Para Leonardo da Vinci, a água era a energia motriz da natureza e símbolo da própria vida. Por isso em suas pinturas se dedica ao estudo da representação de seus vários estados, desde a evaporação e condensação das nuvens a seu estado sólido em forma de neve. (cf. Argan, op.cit., p. 259). 
Ao assumir uma visão fenomênica da natureza, Da Vinci buscava chegar a uma forma de perspectiva natural que fosse contraposta ao artificialismo da perspectiva geométrica - o que não significava ficar restrito às aparências naturais, mas penetrar a realidade através de sua experiência direta, dando o estatuto de fenômeno àquilo que se não se oferece imediatamente como tal. Inventa a perspectiva aérea mediante a qual se testemunha uma dilatação do espaço: a distância deixa de ser representada a partir de uma composição por planos degradantes e passa a ser expressa pela oscilação entre luz e sombra, o que conseqüentemente destrói os limites dos contornos das coisas "na fusão unitária da vibração do claro-escuro” ${ }^{\text {.94 }}$.

É na atmosfera que o artista irá encontrar o veículo para luz, a maneira de torná-la transmissível ou dar-lhe forma visível. E aqui então se mostra a importância determinante que a água como elemento-chave para compreensão da natureza tem para definição desta perspectiva: a visibilidade da luz depende da espessura, e portanto da umidade do ar, que muda conforme os níveis de vapores em suspensão. Por isso as paisagens de Da Vinci serão marcadas pela alternância constante entre transparência e opacidade.

É significativo que Guignard pareça reencontrar o ponto de vista fenomênico de Leonardo em suas paisagens de contornos mais diluídos do final da vida, nas quais a presença de estados de liquefação e evaporação levariam ao limite a experiência de impermanência diante do mundo natural e sua representação. Em um grupo de telas realizadas em 1961 [fig.23], é notável como o espaço é composto por massas atmosféricas mais ou menos densas sobre as quais a força ascensional dos balões coloridos já não tem

\footnotetext{
${ }^{94}$ Op. cit. P. 208.
} 
nenhum poder. Ou seja, em Guignard a partir do momento em que a matéria se torna mais diluída, ela se mostra com uma concretude quase intransponível. Curiosamente, ele transforma aquilo que para Da Vinci ainda se apresenta como um "assunto" da pintura - as transformações do mundo natural - em diluição da própria matéria pictórica.

Sendo assim, não é possível minimizar o diálogo que ele trava com a tradição ao longo de sua produção, ou apenas generalizá-lo como algo dentro de um contexto maior de "volta à ordem”, pois esta é filtrada com sutileza a partir de um olhar bastante particular. O que não significa, como acreditamos que ficou claro, que queremos apontar os "mestres antigos” como a única “chave” para compreensão de se trabalho. Na verdade, ao nos referirmos à ligação de Guignard com esses artistas pensamos, sobretudo, em mostrar sua maneira de operar vis-à-vis com a tradição que em seus melhores momentos não recai em tradicionalismos nem arcaísmo, na medida em que a observação de obras do passado se torna parte constitutiva de uma experiência moderna que lhe é própria.

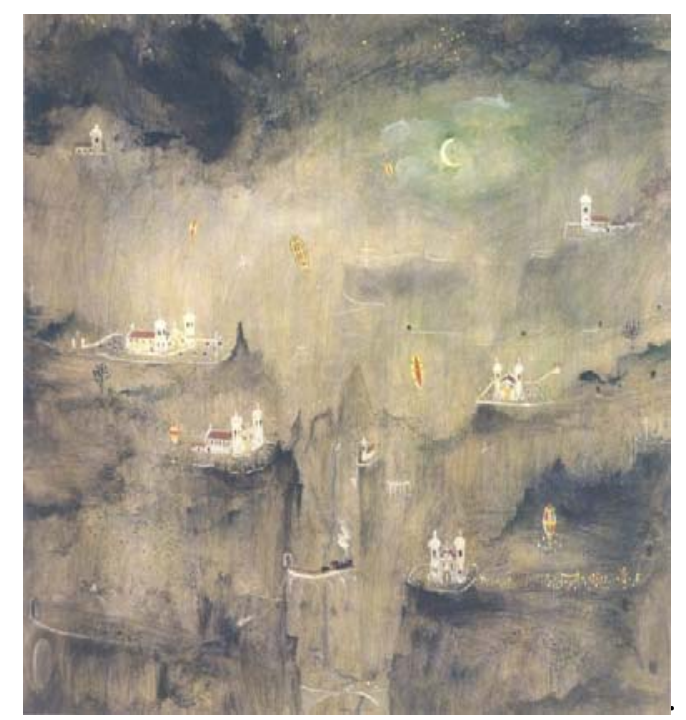

FIG. 23 - NOITE DE SÃO JOÃO, 1961 (ÓLEO SOBRE MADEIRA, 50 X 46 CM) 


\section{CONSIDERAÇÕES FINAIS}

Indicar os traços da tradição artística que estão presentes na obra de Guignard não significa contradizer o depoimento que sobre ele dá um de seus alunos mais ilustres, Iberê Camargo, quando este diz que o mestre "não era um intelectual, era instinto puro... intuição pura. Era um artista profundamente intuitivo” ${ }^{95}$. Porquanto no caso de Guignard trata-se também daquela "ciência intuitiva” à qual se refere o filósofo Merleau-Ponty ao analisar a pintura de Cézanne. Como no trabalho do pintor francês, não cabe negar a tradição ${ }^{96}$. Busca-se, na verdade, fazer com que as relações abstratas intervenham no ato de pintar a partir de sua regulação pela observação do mundo visível. E isso inclui um duplo movimento: de esquecimento de toda ciência para recuperar, por meio delas, a experiência primordial de onde todas as noções e conceitos são tirados. É encontrar o ponto de equilíbrio em que “a arte não é nem imitação, nem, por outro lado, uma fabricação segundo os desejos do instinto ou do bom gosto. É uma operação de expressão”"97. Sendo assim, o artista trabalha com uma linguagem que já é dada, mas que pode ser recriada a todo instante.

Essa atitude do sujeito-artista, pouco importa se consciente ou não, pressupõe que seus motivos não sejam visados apenas enquanto temas ou assuntos a serem retratados, mas

\footnotetext{
${ }^{95}$ Depoimento de Iberê CAMARGO reproduzido in: A modernidade em Guignard, p. 135.

${ }^{96}$ Tradição esta que começa, como se sabe, desde a escolha de um suporte retangular liso e polido como medium para representação do campo pictural, e que, enfim, é uma invenção histórica, como bem lembra Meyer SCHAPIRO em "Sur quelques problèmes de sémiotique de l'art visuel: champ et véhicule das les signes iconiques”, in: Style, artiste et société, pp. 7-34.

${ }^{97}$ Maurice MERLEAU-PONTY, “A dúvida de Cézanne”, in O olho e o espírito, p. 133.
} 
antes como um meio de tornar realidade visível uma experiência que é fugaz ${ }^{98}$. Neste sentido é que muitas das pinturas de Guignard, pelo menos naquelas em que ele parece mergulhar com afinco nesta busca, têm a aparência imaterial das evocações. O que para compreensão de sua poética é bastante revelador. Porque, diferentemente de Cézanne, o mundo de Guignard sugere uma espessura mais rarefeita. Como foi dito, este se compraz nas transparências e na qualidade volátil de seus volumes, retirando da matéria do mundo parte de sua fisicalidade imperiosa.

A observação concentrada e próxima do motivo se junta ao distanciamento que perde das coisas seus contornos, embaça-os, produzindo assim uma tensão constante entre interior e exterior, real e imaginário, a figura e sua abstração, o definido e o apenas insinuado, o espaço que não indica exatamente um além, mas que também não chega a sugerir uma continuidade do campo visual com aquele do espectador. Permanece ali, congelado no estiramento vertical de seus horizontes a evidenciar os limites do campo pictórico sem extrapolá-los. Trata-se com certeza duma posição ambígua, talvez num limiar, mas que não deixa de ser legítima e plena de sentido, pois a maneira como o artista entrega-se à percepção sem a adesão anterior a um estilo "moderno", ou sem o peso de um discurso a ser ilustrado, torna seus trabalhos singulares na esfera do nosso modernismo.

Neste sentido, é que acreditamos que seu lirismo ancora-se sobre um ponto de vista para além de uma justificação puramente nacionalista. Mesmo porque, como acreditamos ter mostrado, muito de seu caráter nacional aparece como elemento decorativo. Há o índice de uma desmesura nessas pequenas figuras, feitas de finos traços coloridos, a flutuar no

\footnotetext{
${ }^{98}$ E aqui talvez também resida outro dado de sua “classicidade”.
} 
espaço. E se é possível falar em ingenuidade diante de suas obras, esta nos interessa enquanto diz respeito tão somente ao ato cognitivo que busca dar expressão àquela percepção originária de quem olha as coisas pela primeira vez. Esse despojamento, que Guignard dizia ser sinceridade diante de seu ofício, nada tem a ver com um conteúdo moral (o homem é bom e assim só vê o bem em torno de si).

Como vimos, sua formação se dá em um meio complexo e heterogêneo, em que a arte moderna não é interpretada de uma única maneira. Correntes romântico-simbolistas, que em geral mantém uma relação de desencanto com a vida moderna, buscando no passado, no mundo dos sonhos ou em outras culturas a Idade de Ouro perdida, convivem, e às vezes se mesclam, às tendências realistas, que enxergam na arte uma função de conhecimento (seja do dado humano e histórico, seja do próprio ato da visão) e denúncia de seu tempo. Trazer à tona esse ambiente, e a passagem de Guignard por ele, auxilia na compreensão da originalidade de sua obra, numa leitura que visa ir além de seu enquadramento local, colocando-a em diálogo com questões importantes de seu tempo que nem sempre são contempladas pelas tendências dominantes da história da arte moderna brasileira. 
Anexos 


\section{IMAGENS}

AdOLF HENGELER (1863-1927)

PINTURAS

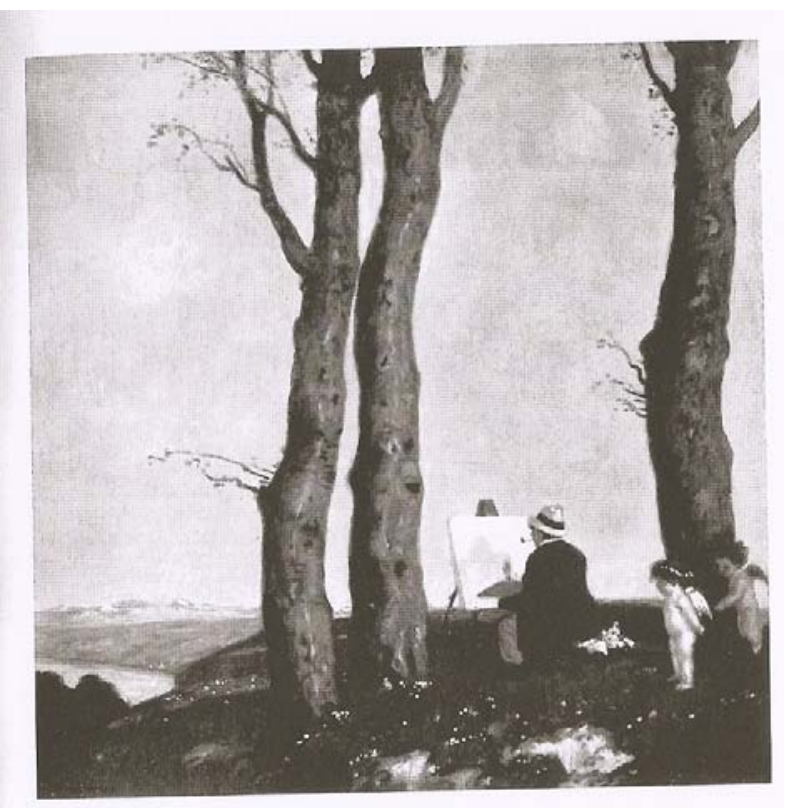

DER MALER

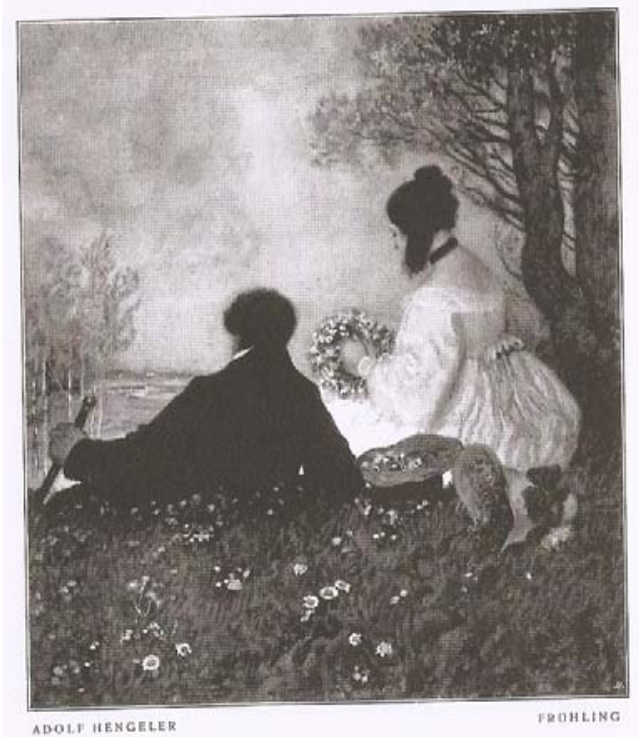

FRÜHLING 


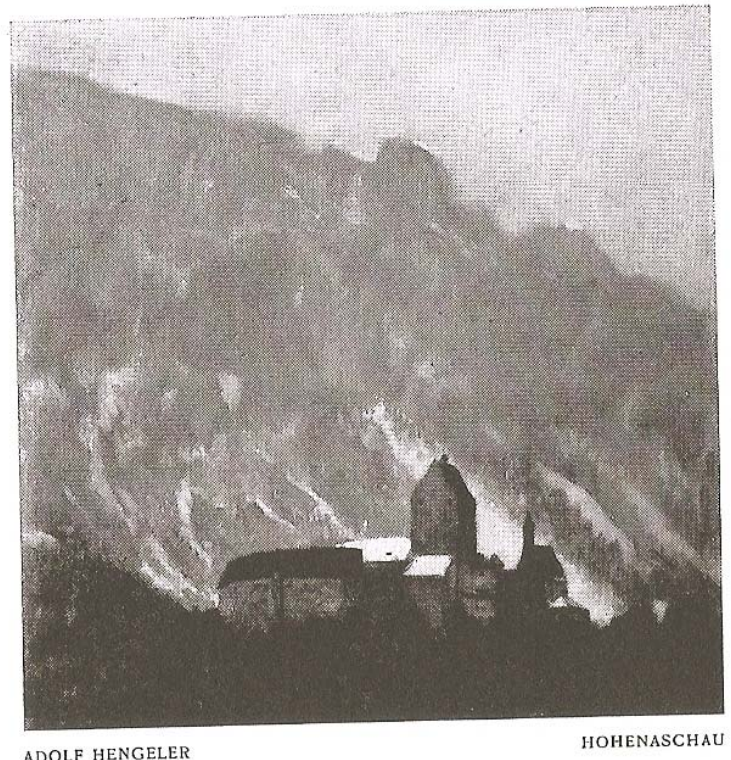

HOHENASCHAU

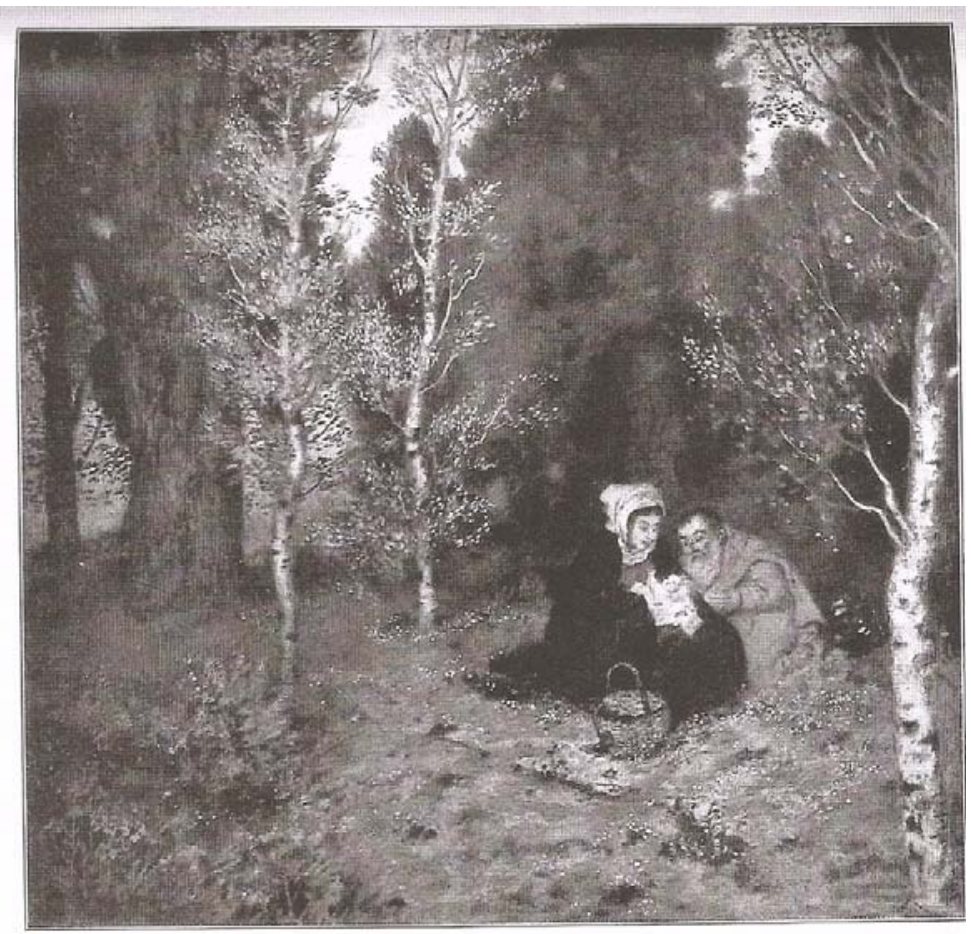

ADOLF HENGELER RUHE AUF DER FLUCHT

RUHE AUF DER FLUCHT, 1902 


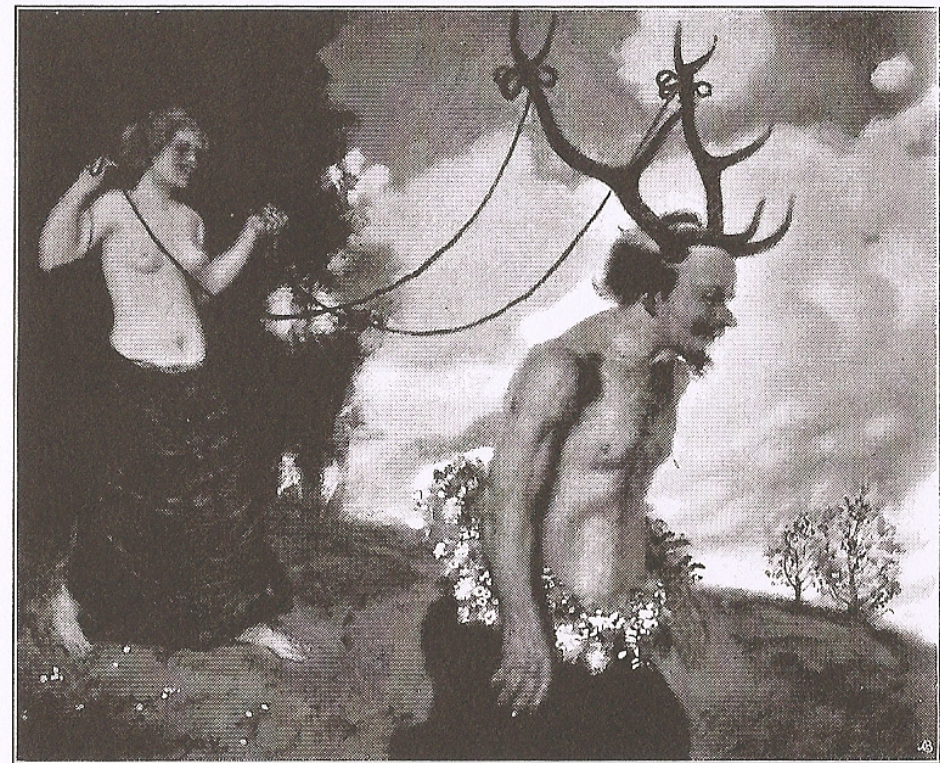

ADOLF HENGELER

DER HIRSCH

DER HIRSCH

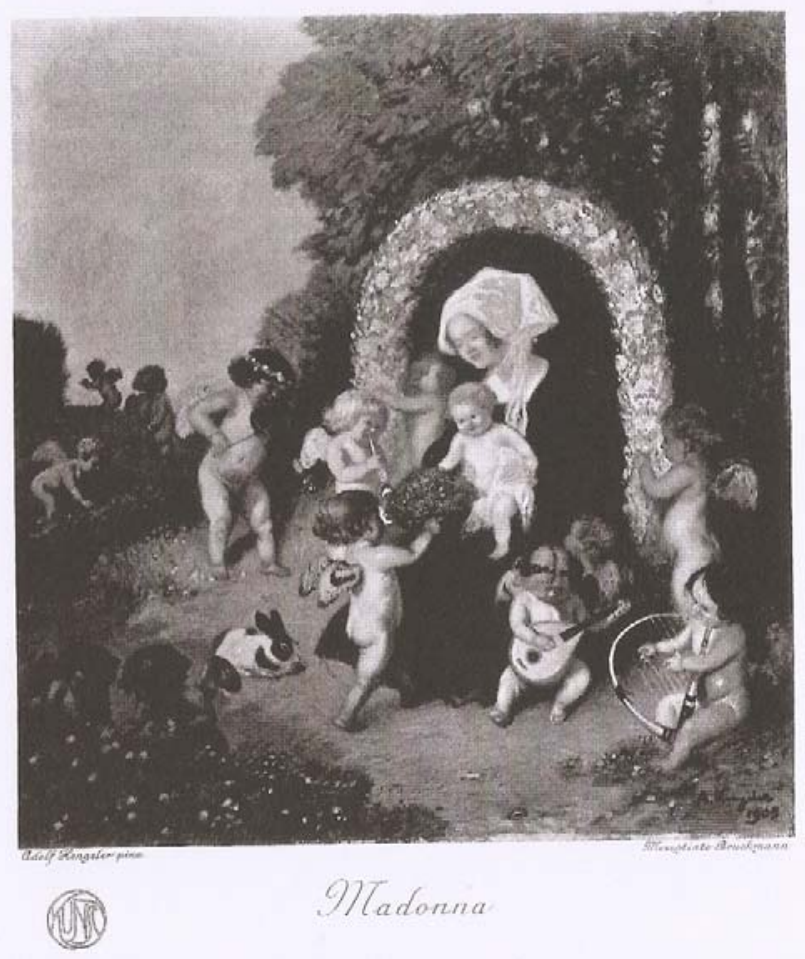




\section{DESENHOS}

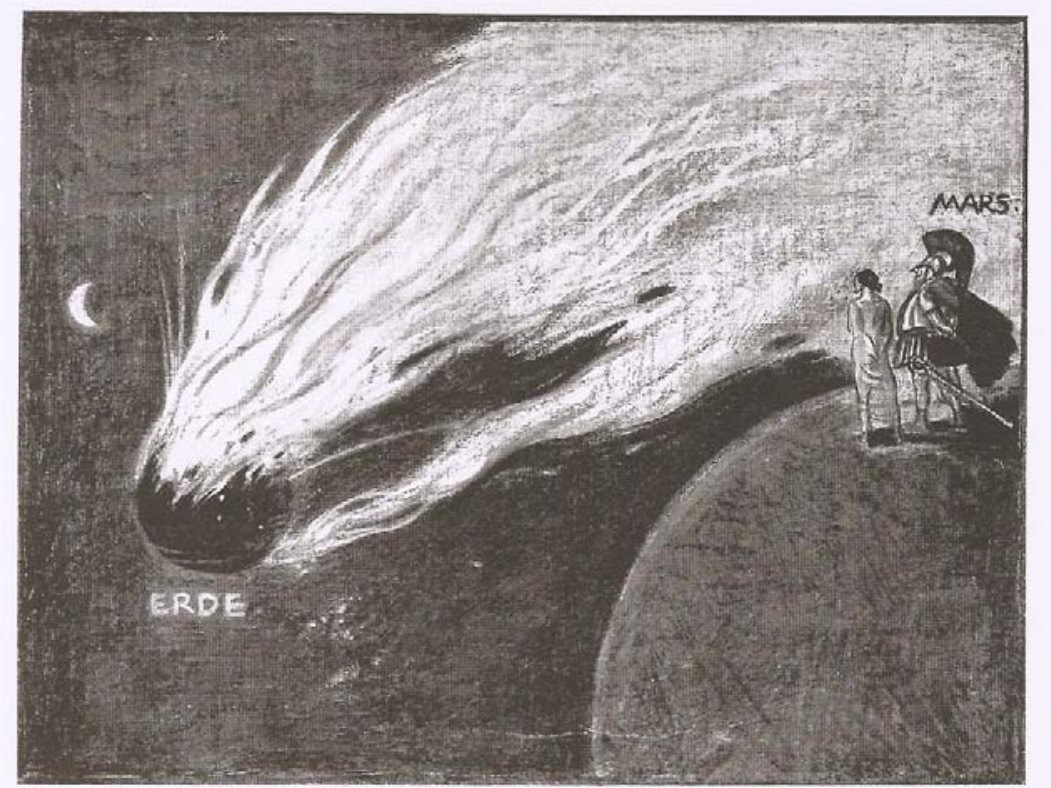

WAS IST DENN MIT DER ALTEN ERDE LOS? -

13. 2. Y.14.AH.

AUS EINEM TAGEBUCH, 1914

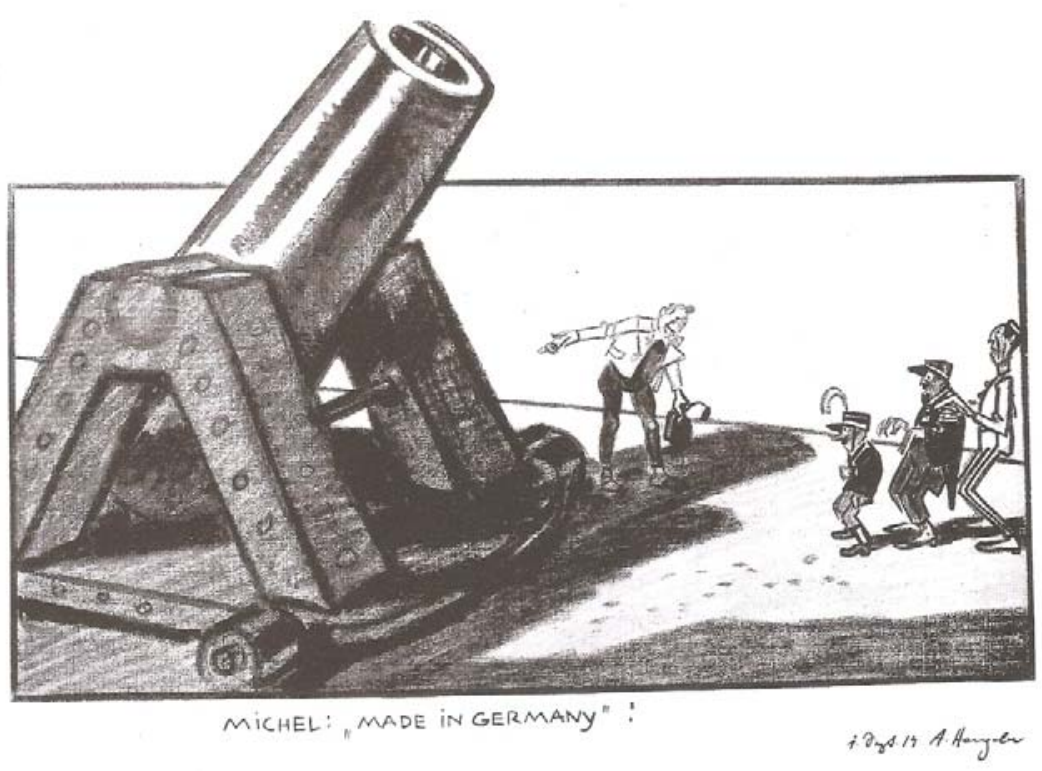

AUS EINEM TAGEBUCH, 1914 

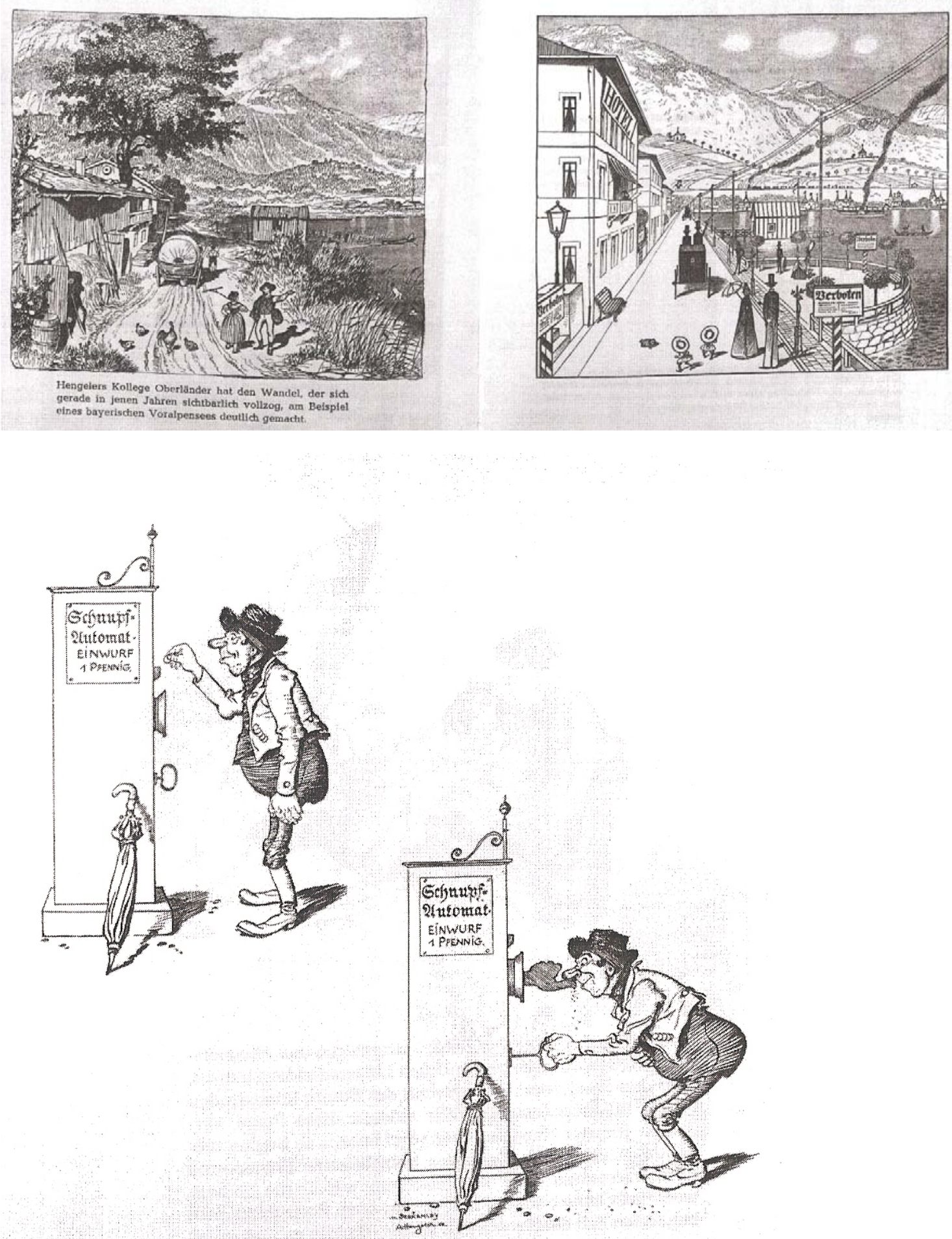

IMAGENS RETIRADAS DO VOLUME HEITERE VISIONEN - ADOLF HENGELER 


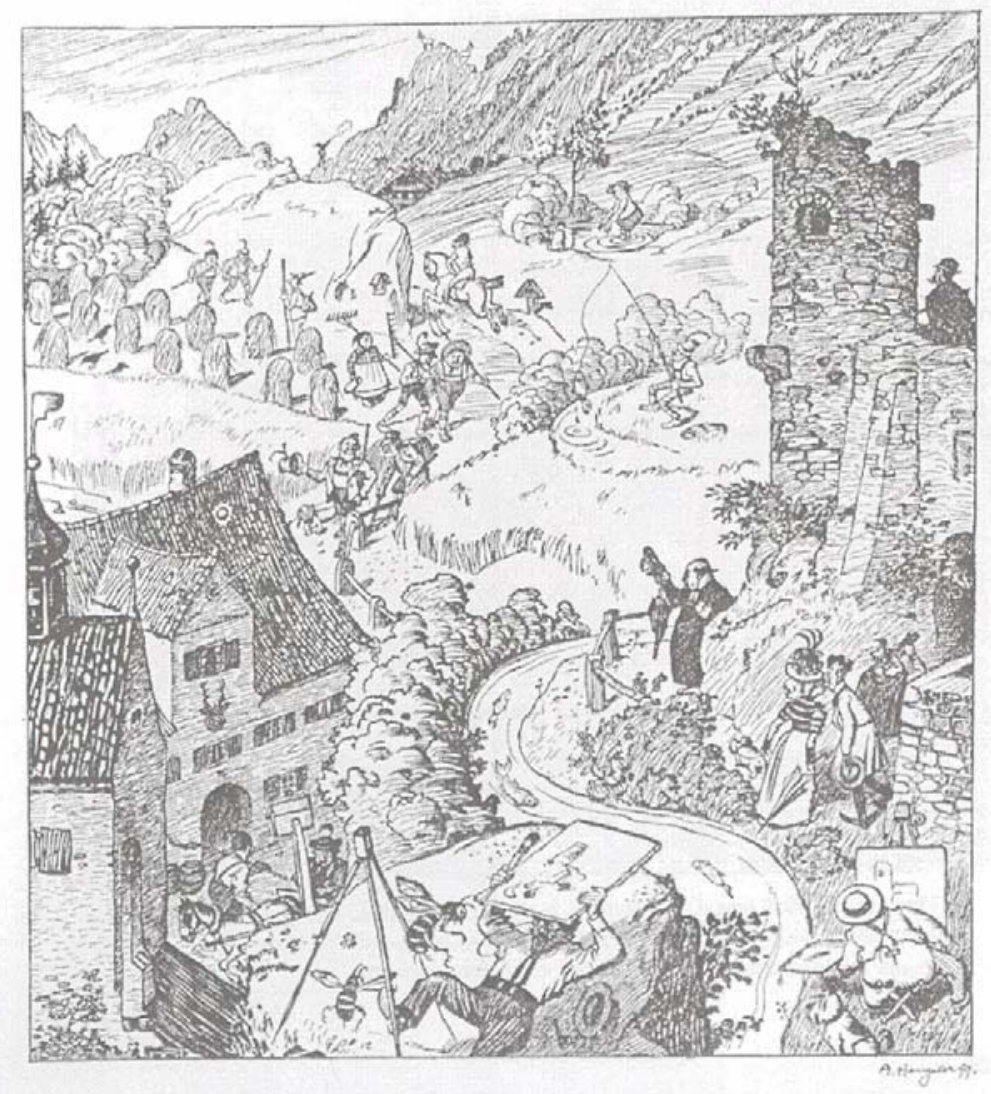

IMAGEM RETIRADA DO VOLUME HEITERE VISIONEN - ADOLF HENGELER

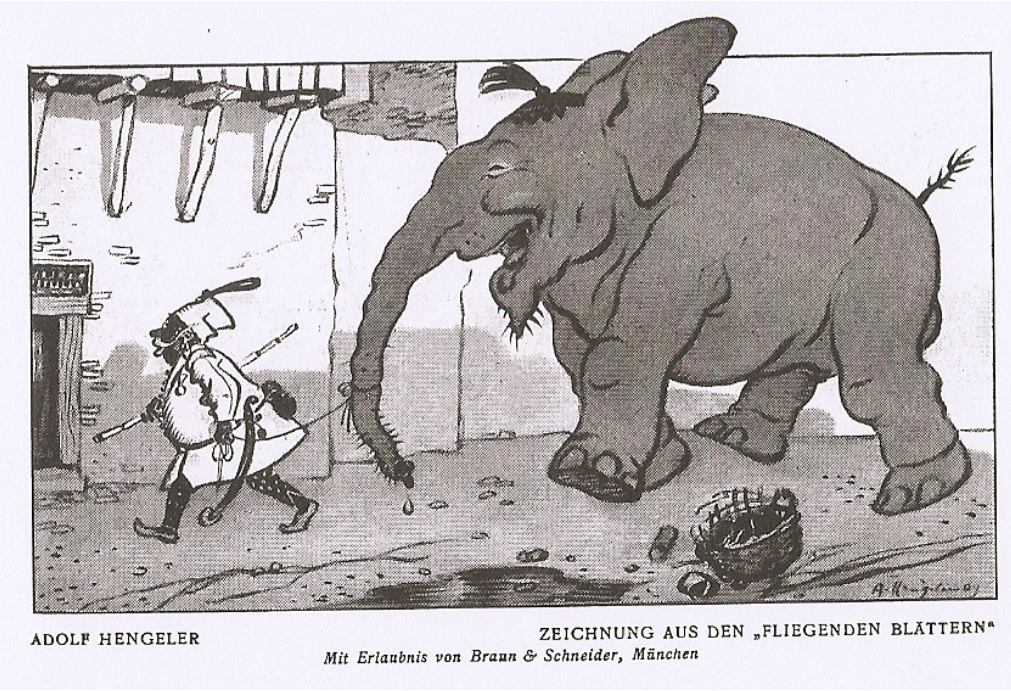

DESENHO PARA FLIEGENDEN BLÄTTER 
IMAGENS

HERMANN GROEBER (1865-1935)

PINTURAS

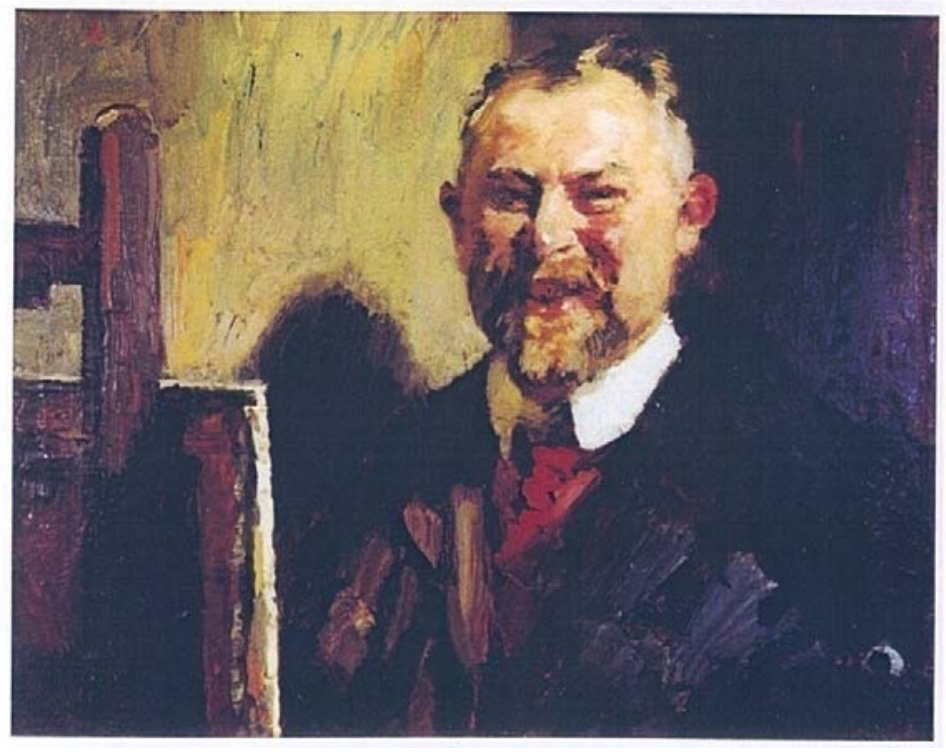

SELBSTBILDNIS, 1910

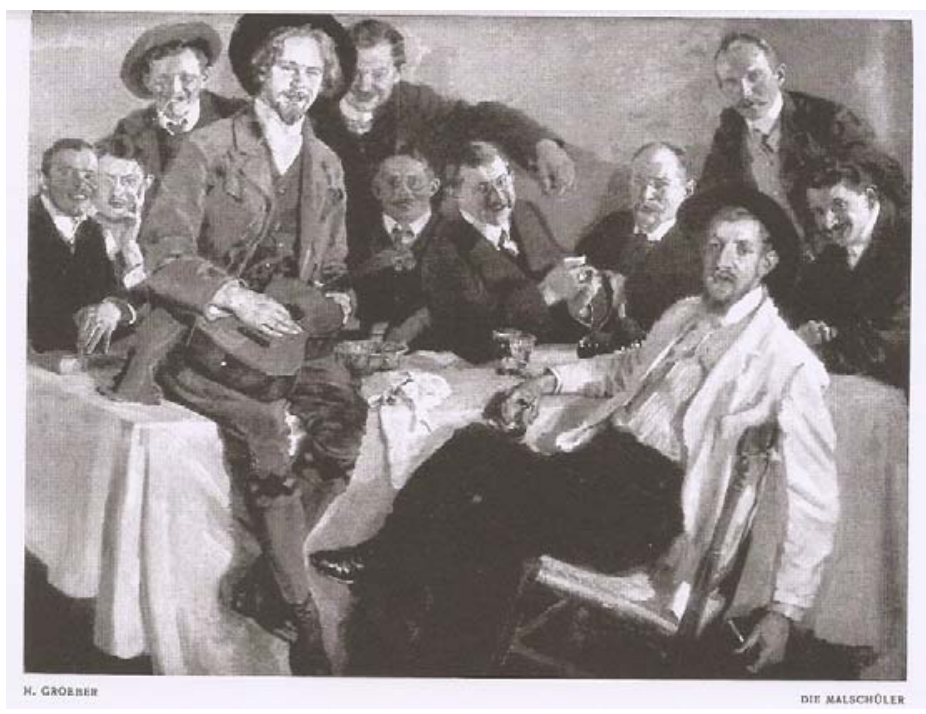

DIE MALSCHÜLER, 1911 


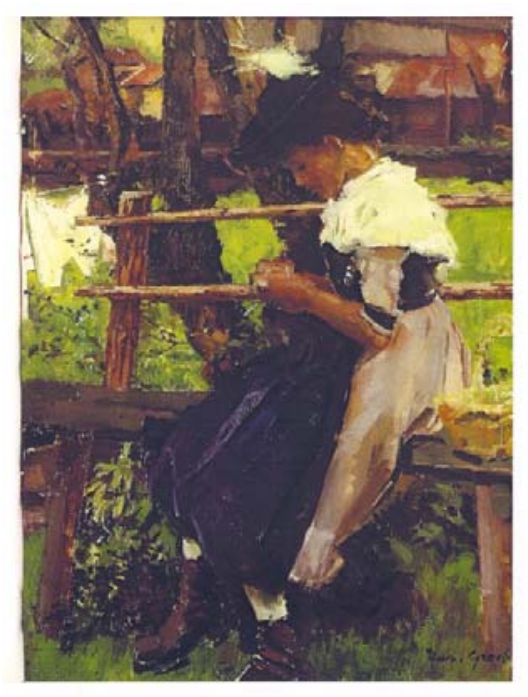

MIESBACHER BAUERNMÄDEL

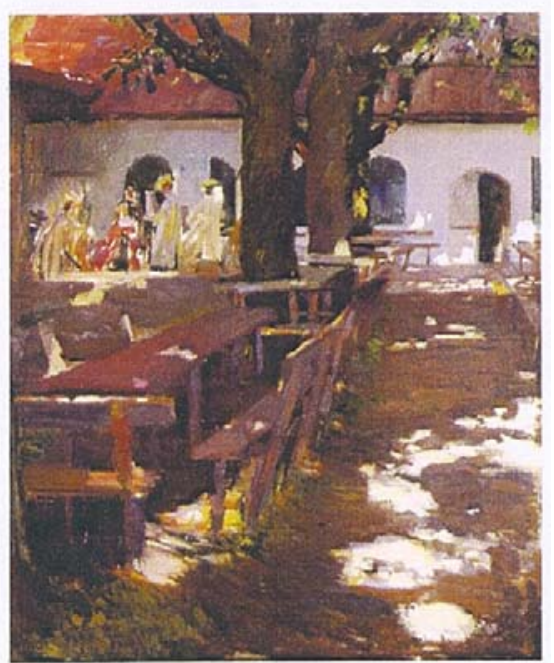

BIERGARTEN

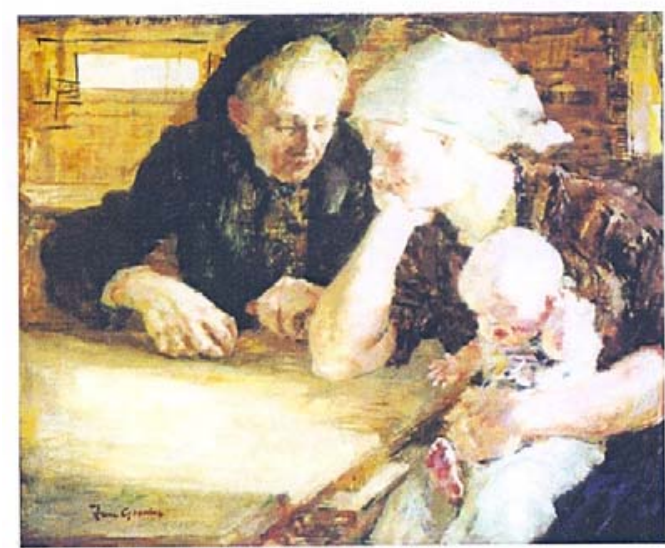

DREI GENERATIONEN 


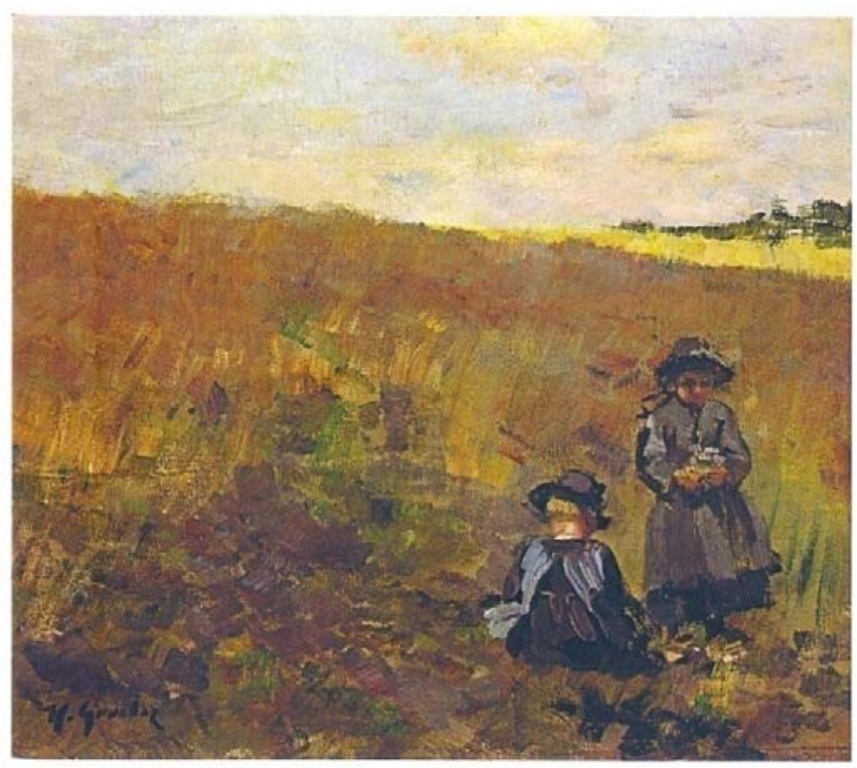

KINDER AUF DEM FELDE

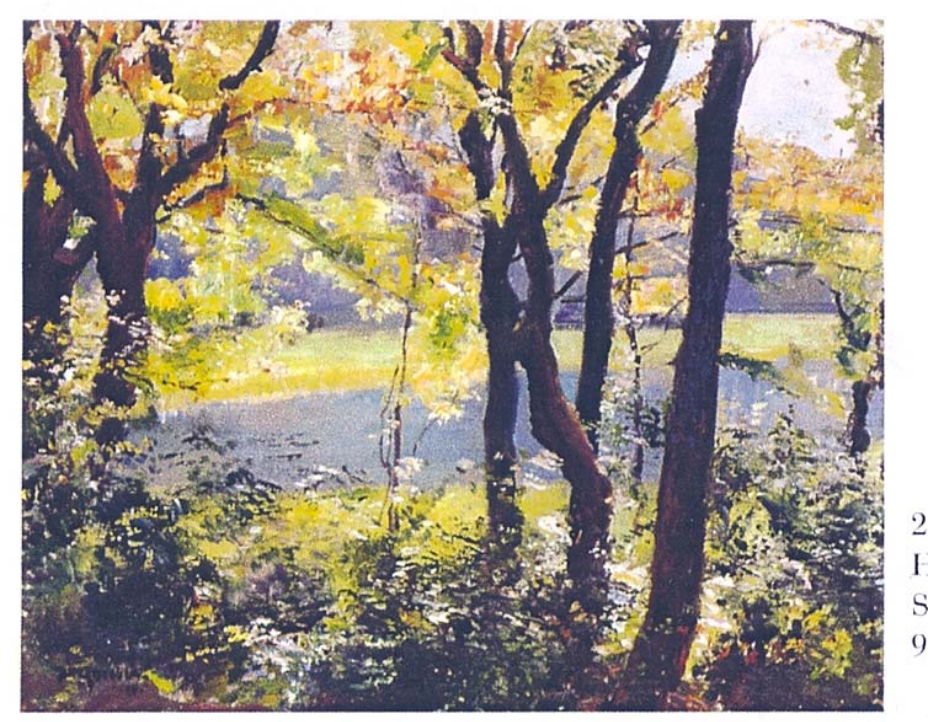

HERBST IN DER SEENPLATTE 


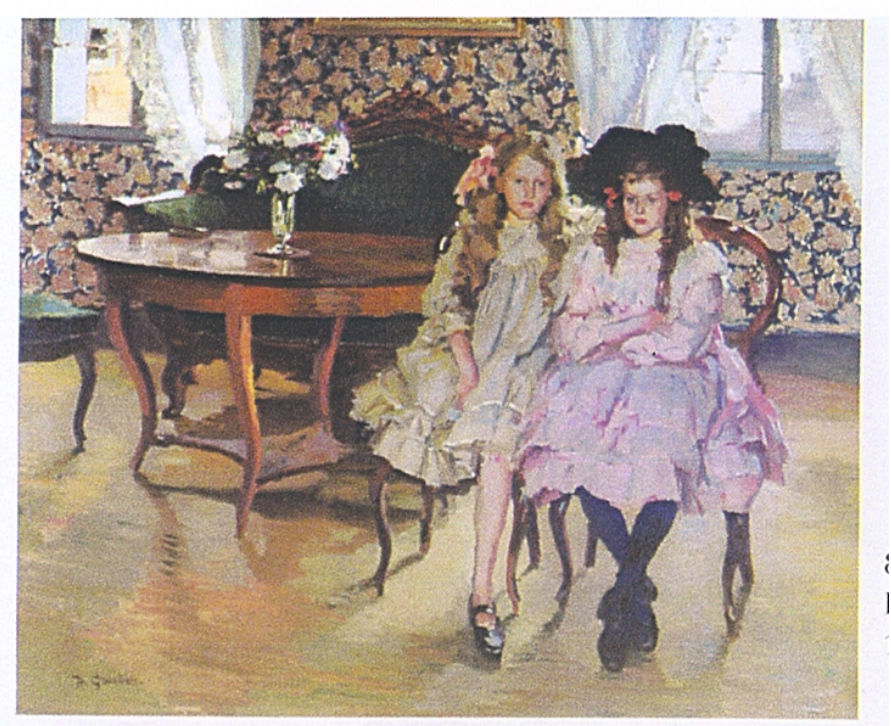

IM BIEDERMEIER ZIMMER

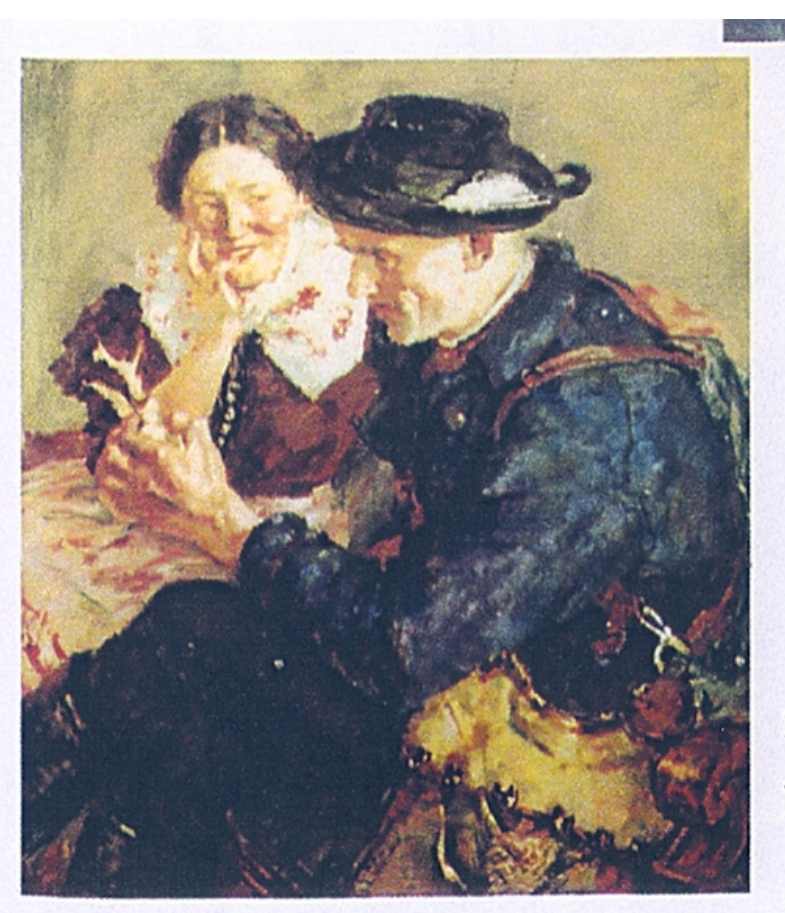

JÄGERLIEBE 


\section{DESENHOS}

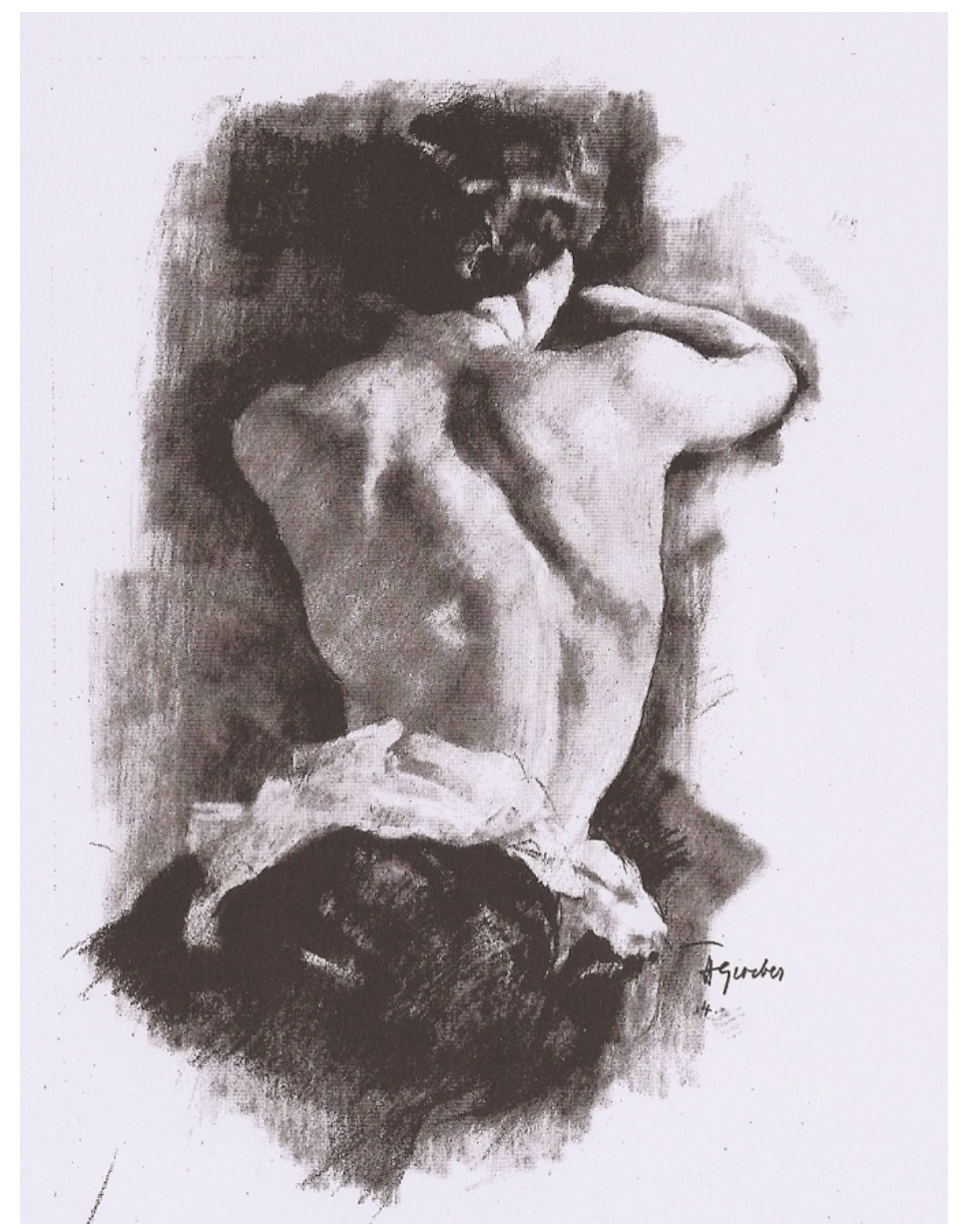

SEM TÍTULO, 1914 


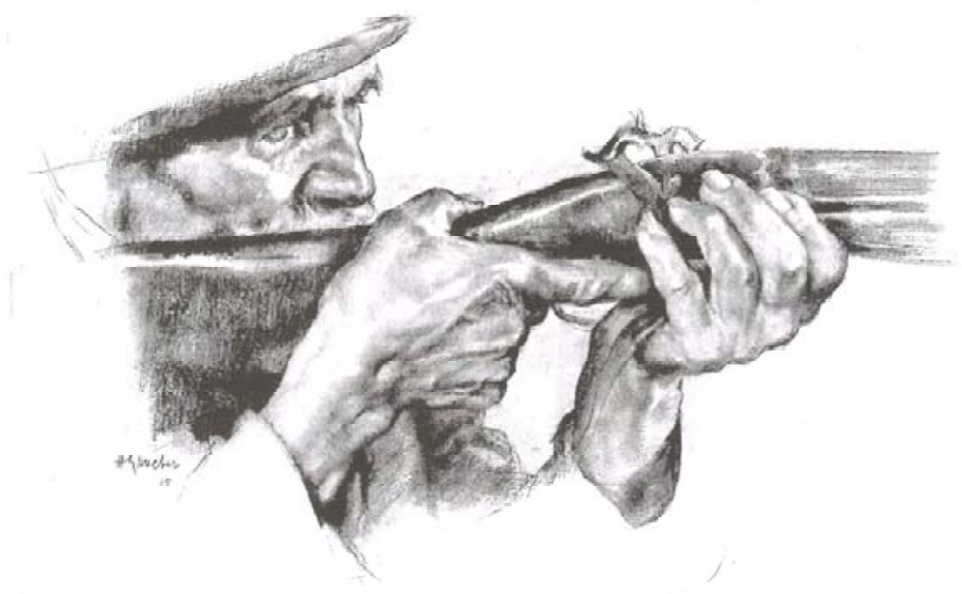

SEM TÍTULO, 1915

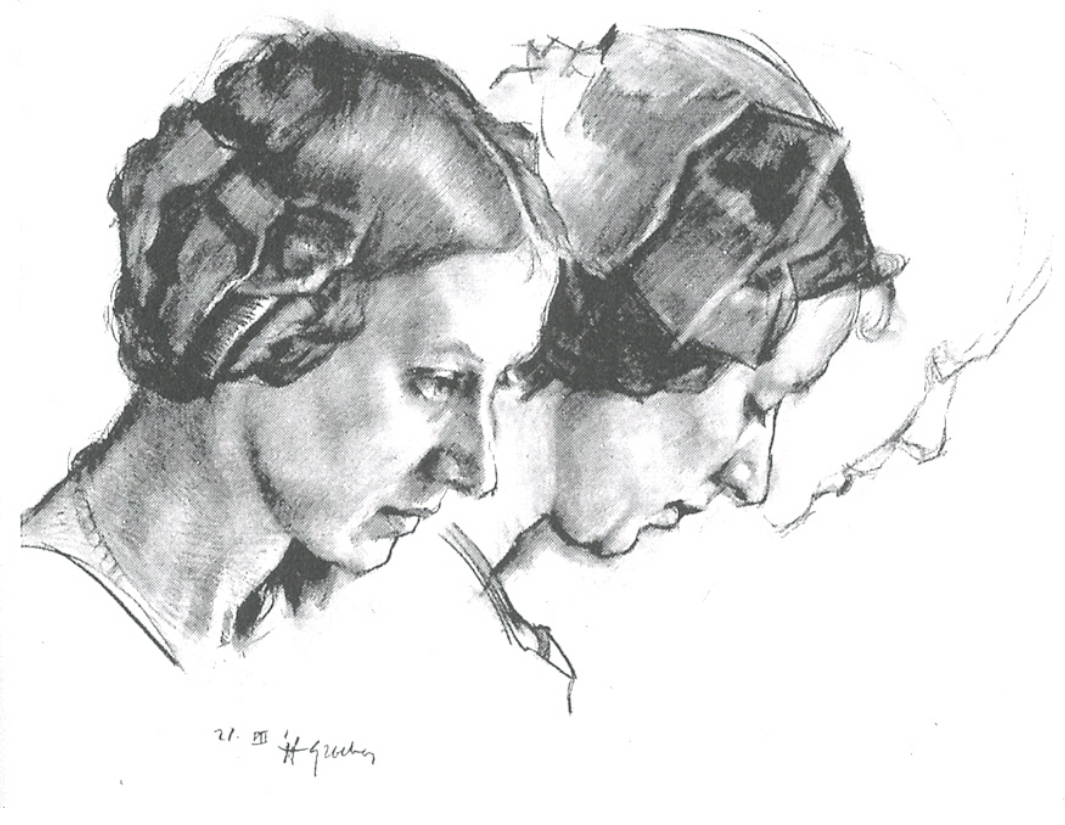

SEM TÍTULO, 1914 


\section{BIBLIOGRAFIA}

\section{SOBRE ALBERTO DA VEIGA GUIGNARD}

\section{ARTIGOS}

AMARAL, Aracy. Quatro cartas de Guignard para Pettoruti. São Paulo: s.d. 8 p. (mimeo).

ANDRADE, Mário de. “O movimento modernista”. In: Mestres do modernismo. São Paulo: Imprensa Oficial, 2005.

ANDRÉS, Maria Helena. Guignard, o mestre. Estudos Avançados, 10 (28), 1996.

BANDEIRA, Manuel. Guignard. Folha de São Paulo, São Paulo, 25 out. 1960. . Guignard. Tribuna da Imprensa, Rio de Janeiro, 21 jul. 1962.

. Um anjo mutilado. Suplemento Literário de Minas Gerais, Belo Horizonte, ano VIII, no 362, 4 agosto 1972.

BRAGA, Rubem. Liberdade para o pintor Guignard. Manchete, 11 dez. 1961.

EDIÇÃO comemorativa de 10 anos de morte de Guignard. Textos de Frederico Morais, Priscila Freira, Mário de Andrade, Manuel Bandeira, Geraldo Ferraz, Lúcia Machado de Almeida. Suplemento Literário de Minas Gerais, Belo Horizonte, ano VIII, nº 362, 4 agosto 1972.

EULÁLIO, Alexandre. Guignard, O Manso. Jornal de Letras, s.l., out. 1962.

GULLAR, Ferreira. Considerações sobre Guignard, Jornal do Brasil, Rio de Janeiro, 27/06/1962.

JAYME Maurício. Guignard - Europa, 1961, Itinerário das Artes Plásticas do Correio da Manhã, 01/12/1961.

LAUS, Harry. Guignard e a paisagem de Minas. Opinião. S.l., ano I, n50, jul. 1972.

LEITE, José Roberto Teixeira. Guignard, Cadernos Brasileiros, ano 10, $\mathrm{n}^{\circ}$, jun/set. 1962. 
MACHADO, Lourival Gomes. Uma notícia comovente. O Estado de São Paulo, São Paulo, 25 nov. 1961.

MORAIS, Frederico. Guignard: um documento-base. Revista do Conselho Estadual de Cultura de Minas Gerais, Belo Horizonte, nº 11, p. 7-21, 1980.

NAVARRA, Ruben. "Iniciação à pintura brasileira contemporânea", in: Modernidade Negociada. São Paulo: Museu de Arte Moderna, 2007.

SAMPAIO, Márcio. Guignard e sua escola. Minas Gerais, Belo Horizonte, 10 jun.1972.

SÃO VICTOR, Raul de. A pintura moderna no Brasil. Suplemento Autores e Livros de A Manhã, Rio de Janeiro, v. VII, p.178. 1/10/1944.

Um museu para a arte moderna. Suplemento Autores $e$ Livros de A Manhã, Rio de Janeiro, 7/11/1943.

VIEIRA, Ivone Luzia. Projeto Guignard: a leitura de sua obra. IN: Projeto Guignard, http://www1.cultura.mg.gov.br/index.php?acao=busca_textosEstudos. Último acesso: 28/10/2010.

\section{CATÁLOGOS, LIVROS, DISSERTAÇÕES}

20 ARTISTAS BRASILEIROS (cat.exp.). Apresentação Marques Rebêlo. Argentina, 1945.

30 ANOS DE ARTE BRASILEIRA (cat. exp.). Texto de Joaquim Cardoso. Rio de Janeiro: Galeria Macunaima, Diretório Acadêmico da Escola Nacional de Belas Artes Universidade do Brasil, 1959.

ALBERTO DA VEIGA GUIGNARD : 1896 - 1962 (cat. exp.). Textos de Rubem Braga; Lúcia Machado de Almeida. Espaço Plano. 7 nov.1983.

ALBERTO DA VEIGA GUIGNARD - 1896-1962. Rio de Janeiro: Edições Pinakotheke, 2005.

BANDEIRA, Manuel. Poemas traduzidos. Ilustrações de Guignard. Rio de Janeiro: R. A. Editora, 1945. 
COLEÇÃO Mário de Andrade. Apresentação de Gilda de Mello e Souza, Marta Rosetti Batista e Yone Soares de Lima. São Paulo: Instituto de Estudos Brasileiros, Universidade de São Paulo, 1998.

BREST, J. R. La pintura brasileña contemporânea. Buenos Aires: Editorial Poseidon, 1945.

BRITO, Ronaldo. Experiência crítica. Organização de Sueli de Lima. São Paulo: CosacNaify, 2005.

DESENHOS DE GUIGNARD - Exposição comemorativa do primeiro aniversário de morte do artista (cat. exp.) Texto de Milton Campos. Belo Horizonte: Pampulha, 25 jun. 1963.

FADEL, Sérgio. Arte moderna no Brasil: o olhar do colecionador. Rio de Janeiro: Edições Fadel, 2006.

FROTA, Lélia Coelho. Guignard, arte, vida. Rio de Janeiro: Campos Gerais, 1997.

GRINBERG, Piedade. Ruben Navarra e a crítica de arte na década de 40 no Rio de Janeiro (dissertação de mestrado). Zílio, Carlos (orientador). Rio de Janeiro: Escola de Belas Artes, Universidade Federal do Rio de Janeiro, 1996.

GUIGNARD (cat. exp.). Texto de Lúcia Machado de Almeida. Rio de Janeiro: Museu de Arte Moderna, 1953.

GUIGNARD (cat. exp.). Belo Horizonte: Museu de Arte da Prefeitura de Belo Horizonte, 1962.

GUIGNARD. Apresentação de Múcio Leão. Col. Mestres do Desenho. São Paulo: Editora Cultrix, 1964.

GUIGNARD. Apresentação de Rodrigo Melo Franco de Andrade. S.l: Ediarte, 1967.

GUIGNARD - 1896-1962 (cat. exp.). Texto de Clarival do Prado Valladares. Belo Horizonte: Museu de Arte, 21 jun- 31 jul. 1972

GUIGNARD: Exposição comemorativa do $20^{\circ}$ aniversário de morte de Alberto da Veiga Guignard (cat. exp.). Texto de Márcio Sampaio. Belo Horizonte: Grande Galeria do Palácio das Artes, 29 jun.- 14 agos. 1982.

GUIGNARD: Uma seleção da obra do artista (cat. exp.). Textos de Rodrigo Naves, Sônia Salzstein, Amilcar de Castro e Iberê Camargo. São Paulo: Centro Cultural São Paulo, Museu Lasar Segall, 1992. 
GUIGNARD: Um mundo a perder de vista (cat. exp.). Apresentação de José Augusto Ribeiro Porto Alegre: Fundação Iberê Camargo, 2009.

HUMANISMO LÍRICO DE GUIGNARD (cat. exp.). Textos de Jean Boghici e Frederico Morais. Rio de Janeiro: Museu Nacional de Belas Artes, 2000.

MACHADO, Lourival G. Retrato da arte moderna do Brasil. São Paulo: Departamento de Cultura, 1947.

MENDES, Murilo. Recordações de Ismael Nery. Apresentação de Davi Arrigucci Jr. . São Paulo: Edusp, 1996.

A MODERNIDADE em Guignard. Textos de Carlos Zílio, Ronaldo Brito, Paulo Sérgio Duarte, Vanda Mangia Klabin, entre outros. Rio de Janeiro: PUC, 1983.

MORAIS, Frederico. Guignard. Rio de Janeiro: Edição Centro de Artes Novo Mundo, 1974.

NAVES, Rodrigo. A forma difícil: ensaios sobre arte brasileira. São Paulo: Editora Ática, 1996.

A NOVA FLOR DO ABACATE, Grupo Guignard - 1943 (cat. exp.). Rio de Janeiro: Galeria de Arte Banerj, 1986.

A PAISAGEM MINEIRA. Belo Horizonte: Paço das Artes, 29 nov.- 20 dez. 1977.

PEDROSA, Mário. Textos escolhidos III - Acadêmicos e modernos. Organização de Otília Arantes. São Paulo: Edusp, 2004.

RIBEIRO, José Augusto. Guignard e o ambiente artístico no Brasil nas décadas de 1930 e 1940 (dissertação de mestrado). Salzstein, Sônia

(orientadora). São Paulo: Departamento de Artes Plásticas, ECA-USP, 2009.

SALZSTEIN, Sônia. A questão moderna: impasses e perspectivas na arte brasileira, 1910 a 1950. (tese de doutorado). São Paulo: Departamento de Filosofia, Universidade de São Paulo, 2000.

VIEIRA, Lúcia G.. Salão de 1931, marco da revelação da arte moderna em nível nacional. Rio de Janeiro: MEC, Funarte, 1984.

\section{ENTREVISTAS}

ANDRADE, Farnese. Sobre Guignard: entrevista-depoimento. [4 de junho, 1982]. Entrevista concedida a Geraldo Edson de Andrade e Mauro Leopoldo do rego 
Barros para Exposição Alberto da Veiga Guignard (1896 - 1962) pinturas e desenhos. Rio de Janeiro, Galeria de Arte BANERJ, 1982 (mimeo).

BEHRING, Edith. Sobre Guignard: entrevista-depoimento. [7 de junho, 1982]. Entrevista concedida a Geraldo Edson de Andrade para Exposição Alberto da Veiga Guignard (1896 - 1962) pinturas e desenhos. Rio de Janeiro, Galeria de Arte BANERJ, 1982 (mimeo).

BENTO, Antônio. Sobre Guignard: entrevista-depoimento. [03 de junho, 1982]. Entrevista concedida a Mauro Leopoldo do Rego Barros para Exposição Alberto da Veiga Guignard (1896 - 1962) pinturas e desenhos. Rio de Janeiro: Galeria de Arte BANERJ, 1982 (mimeo).

GUIGNARD, Alberto da Veiga. Entrevista concedida a Carlos Galvão Krebs. Belo Horizonte, 25/02/1948 (mimeo).

SANTOS, Pierre. Passos de Guignard em Ouro Preto: entrevista. [23 de outubro, 2003]. Belo Horizonte: Projeto Guignard. Entrevista concedida a Gélcio Fortes. http://www1.cultura.mg.gov.br/index.php?acao=busca_legendasEntrevistas. Último acesso: 28/10/2010.

\section{CARTAS}

GUIGNARD, Alberto da Veiga. [Mon bien cher ami Pettoruti]. Rio de Janeiro: dez. 1930. 4 f. Arquivo Fundação Pettoruti (manuscrito).

. [Cher ami Pettoruti]. Rio de Janeiro: [1931?]. 3 f. Arquivo Fundação Pettorutti (manuscrito).

05/03/1931. 2 f. Arquivo Fundação Pettoruti (manuscrito).

. [Cher ami Pettoruti]. Rio de Janeiro: 13/04/1931.

2 f. Arquivo Fundação Pettoruti (manuscrito).

[Muito Prezado e Caro Amigo Alcides da Rocha Miranda]. Belo Horizonte: [1950?] 1f. Arquivo Guignard, PUC, Rio de Janeiro (manuscrito).

[Excelmo. Senhor Mario de Andrade]. Rio de Janeiro:

15/02/1934. 3 f. Fundo Mário de Andrade/ IEB-USP (manuscrito). 
[Muito Prezado Senhor e Amigo Mario de Andrade]. Rio de Janeiro: 23/05/1935. 2 f. Fundo Mário de Andrade/ IEB-USP (manuscrito).

[Muito Prezado Amigo Dr. Mario de Andrade]. Rio de Janeiro, 05/ 02/ 1944. 1f. Fundo Mário de Andrade/ IEB-USP (manuscrito).

[Prezado e grande amigo Alcides]. Belo Horizonte: 02/02/1952. 1f. Arquivo Guignard, PUC, Rio de Janeiro (datilografado).

. [Muito prezado e caro amigo Alcides]. Belo Horizonte, 12/ 09/ 1952. 1 f. Arquivo Guignard, PUC, Rio de Janeiro (datilografado).

\section{ARQUIVOS E SITES}

- $\quad$ Arquivo Pesquisa Guignard - PUC, Rio de Janeiro, RJ.

- $\quad$ Arquivo Museu Casa Guignard - Ouro Preto, MG.

- $\quad$ Arquivo Akademie der Bildenden Künste - Munique, Alemanha.

- $\quad$ Fundo Mário de Andrade/IEB-USP - São Paulo, SP.

- $\quad$ Projeto Guignard: http://www1.cultura.mg.gov.br/

- $\quad$ Pesquisa Guignard: http://guignard.dcc.ufmg.br/guignard/

- $\quad$ Akademie der Bildende Kunste Munchen: http://www.adbk.de/index.php

\section{BIBLIOGRAFIA COMPLEMENTAR}

ALMEIDA, Paulo Mendes. De Anita ao museu. São Paulo: Perspectiva, 1976.

AMARAL, Aracy. Tarsila: sua obra e seu tempo. São Paulo: Edusp, Perspectiva, 1975.

Arte para quê?: a preocupação social na arte brasileira (19301970). São Paulo: Studio Nobel, 2003.

ARGAN, Giulio Carlo. A arte moderna. São Paulo: Companhia das Letras, 1996. 
Clássico anticlássico. São Paulo: Companhia das Letras, 1999.

. A arte italiana. São Paulo: São Paulo: CosacNaify, 2006.

A arte moderna na Europa. São Paulo: Companhia das Letras,

2010.

ARRIGUCCI, Davi Jr. O cacto e as ruínas: a poesia entre outras artes. São Paulo: Livraria Duas Cidades, Editora 34, 2000.

ART in Theory (1815-1900). Harrison, C.; Wood, Paul (orgs). London: Blackwell, 2005.

ART in Theory (1900-2000). Harrison, C.; Wood, Paul (orgs). London: Blackwell, 2002.

ARTE MODERNA no Salão Nacional - 1940/1982 (cat. exp.). Rio de Janeiro: Funarte, 1983.

BANDEIRA, Manuel. Crônicas da província do Brasil. São Paulo: CosacNaify, 2006.

José Olympio Editora, 1987.

Estrela da vida inteira: poesias reunidas. Rio de Janeiro:

BENJAMIN, Walter. Obras escolhidas I. São Paulo: Brasiliense, 1994.

BOIS, Yve-Alain. A pintura como modelo. Col. Mundo da Arte. São Paulo: Martins Fontes, 2009.

BRAUNGART, Richard. Adolf Hengeler - zum 50. Geburtstag des Künstler. Die Kunst für Alle, XXVIII, München, F. Bruckmann A. G., märz 1913.

CALLADO, Antonio. Candido Portinari. São Paulo: Edições Finambrás, 1997.

CÂNDIDO, Antonio. “A revolução de 1930 e a cultura”, in: A educação pela noite e outros ensaios. São Paulo: Ática, 1987.

CHAUÍ, Marilena. Notas sobre cultura popular, Arte em Revista 3 - questão O popular, São Paulo: CEAC, Kairós, [198?].

CHIARELLI, Tadeu. Arte internacional brasileira. São Paulo: Lemos Editorial, 1999.

Galeria de Arte do Sesi, 2008.

Segall realista (cat. exp.). São Paulo: Museu Lasar Segall, 
CLARK, Kenneth. L’art du paysage. Paris: Gperard Monfort Éditeur, 1998.

COTRIM, Cecília; FERREIRA, Glória (orgs.). Clement Greenberg e o debate crítico. Textos de Clement Greenberg, Yve-Alain Bois, T. J. Clark, Leo Steinberg et alli. Rio de Janeiro: Zahar, 2001.

DAMISCH, Hubert. Théorie du nuage: pour une histoire de la peinture. Paris: Éditions du Seuil, 1972.

FABRIS, Annateresa (org.). Modernidade e modernismo no Brasil. Campinas: Mercado de Letras, 1994..

Perspectiva, Edusp, 1990. Portinari, pintor social. São Paulo: Editora

FLÄMISCHE MALEREI Alte Pinakothek. Ostfildern: Hatje Cantz Verlag, 2009.

FOSTER, H.; KRAUSS, R.; BOIS, Y.; BUCHLOH, B. Art since 1900 modernism, antimodernism, postmodernism. New York: Thames \& Hudson, 2007.

FRASCINA, F; HARRISON, C. (org.) Primitivismo, cubismo, abstração. São Paulo: CosacNaify, 1998.

(org.). Modernidade e modernismo. São Paulo:

CosacNaify, 1998.

FRY, Roger. Visão e forma. São Paulo: CosacNaify, 2002.

GOMBRICH, E. H. Arte e ilusão. São Paulo: Martins Fontes, 2002. . The preference for the primitive. London: Phaidon Press, 2002. . Norma e forma. São Paulo: Martins Fontes, 1990.

GRASSKAMP, Walter; JOOSS, Birgit. Chronik der Akademie der Bildenden Künste München 1770 2008, in: http://www.adbk.de/Historisches/chronik/chronik_1770-1920.php. Último acesso: $11 / 10 / 2009$.

GREENBERG, Clement. Arte e cultura. São Paulo: Ática, 1996.

HENGELER, Adolf. Heitere Visionen. Kempten: Verlag für Heimatpflege, 1963.

HERMANN GROEBER (17. Juli 1865 - 24. Juni 1935): Gedächtnis Ausstellung (cat.exp.). München: Akademie der Bildenden Künste, Juli-August 1936. 
HERMANN GROEBER zum Gedächtnis (cat.exp.). Nürnberg: Fritz Ofterchrift Verlag, 1938.

HERMANN GROEBER - 1865/ 1935 (cat. exp.). Wartenberg, 2002.

IANNI, Octávio. A idéia de Brasil Moderno. São Paulo: Editora Brasiliense, 2004.

KLABIN, Vanda. 6 perguntas sobre Volpi: um debate sobre arte brasileira. Entrevista com Alberto Tassinari, Lorenzo Mammì, Paulo Pasta, Paulo Sérgio Duarte, Rodrigo Naves e Sônia Salzstein. São Paulo: Instituto Moreira Salles, 2009.

KLEE, Paul. Diários. São Paulo: Martins Fontes, 1990.

LONGHI, Roberto. Breve mas verídica história da pintura italiana. São Paulo: Cosac Naify, 2005.

MAKELA, Maria. The founding and early years of the Munich Secession. Stanford University, Department of Art, 1986.

MAMMÌ, L. Volpi. Col. Espaços da Arte Brasileira. São Paulo: CosacNaify, 1999.

Cebrap, julho 2001.

Mortes recentes da arte, Novos Estudos, v. 60. São Paulo:

MEISTER, Jochen (org.). Münchner Secession: Geschichte und Gegenwart. München, Berlin: Prestel Verlag, 2007.

MELLO e SOUZA, Gilda. Exercícios de leitura. São Paulo: Livraria Duas Cidades, 1980.

MERLEAU-PONTY, Maurice. O olho e o espírito. São Paulo: Cosac Naify, 2004.

MORAIS, Frederico. Núcleo Bernardelli: arte brasileira nos anos 1930 e 1940. Rio de Janeiro: Pinakotheke, 1982.

NAVES, Rodrigo. O vento e o moinho. São Paulo: Companhia das Letras, 2007.

Naify, 1999.

Goeldi. Col. Espaços da Arte Brasileira. São Paulo: Cosac

NOVECENTO SUDAMERICANO: Relazioni artistiche tra Italia e Argentina, Brasile, Uruguay. Milano: Skira, 2003.

ORTIZ, Renato. A moderna tradição brasileira: cultura brasileira e indústria cultural. São Paulo: Brasiliense, 2006. 
OSTINI, F.v.. Adolf Hengeler. Die Kunst für Alle, XX, München, F. Bruckmann A. G., märz 1905.

Aus einem Tagebuch 1914 von A. Hengeler. Die Kunst für Alle, XXX, München, F. Bruckmann A. G., 1915.

. Phantasien von Adolf Hengeler. Die Kunst für Alle, XXXVIII, München, F. Bruckmann A. G., september 1923.

PEDROSA, Mário. Política das artes - Textos escolhidos I. São Paulo: Edusp, 1995.

2000.

Modernidade cá e lá - Textos escolhidos IV. São Paulo: Edusp,

RAPETTI, R. Symbolism. Paris: Flammarion, 2005.

LES RÉALISMES, 1919-1939. Vários autores. Paris: Centre Georges Pompidou, 1981.

SALZSTEIN, Sônia. Volpi. Rio de Janeiro: Campos Gerais, 2000.

SCHAPIRO, Meyer. Style, artiste et societé. Paris: Gallimard, 1999.

CosacNaify, 2004.

Impressionismo: reflexões e percepções. São Paulo:

SCHWARZ, Roberto. Que horas são? São Paulo: Companhia das Letras, 1987.

UM SÉCULO de arte brasileira - Coleção Gilberto Chateaubriand (cat. exp.). Rio de Janeiro: TEKNE Projetos Culturais, 2006.

TASSINARI, Alberto. O espaço moderno. São Paulo: CosacNaify, 2001.

STEINBERG, Leo. Outros critérios. São Paulo: Cosac Naify, 2008.

VENÂNCIO FILHO, Paulo. Goeldi: um expressionista nos trópicos. Novos Estudos, v. 40. São Paulo: CEBRAP, 1993.

Cosac Naify, 1999.

Dacosta. Col. Espaços da Arte Brasileira. São Paulo:

VENTURI, Lionello. El gusto de los primitivos. Madri: Alianza Editorial, 1991. 
WICHMANN, Siegfried. Secession. Europäische Kunst um die Jahrhundertwende (Cat. Exp.). München: Haus der Kunst, 14/03 a 10/05/1964.

WOLF, G. J.. Hermann Groeber, Die Kunst für Alle, XXX, München, F. Bruckmann A. G., september 1915.

ZACHARIAS, Thomas (org.). Tradition und Widerspruch: 175 Jahre Kunstakademie München. München: Prestel Verlag,

ZANINNI, Walter. A arte no Brasil nas décadas de 1930-1940: o grupo Santa Helena. São Paulo: Nobel, Edusp, 1991.

ZÌLIO, Carlos. A querela do Brasil: a questão da identidade da arte brasileira. Rio de Janeiro: Relume Dumará, 1997. 